1.10

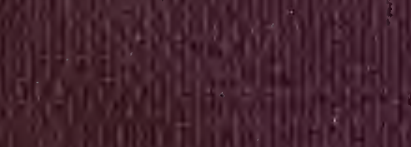

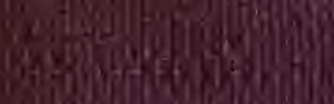

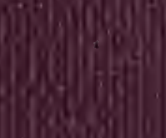

(6) 


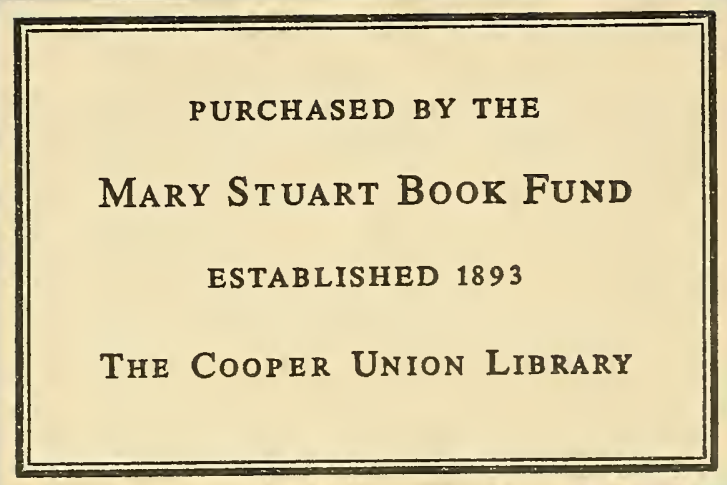












\section{COLOUR AESTHETICS}

COMBINATIONS OF COLOURS WITH TINTS AND WITH SHADES

BY

F. LOUIS BARBER, B.A. 


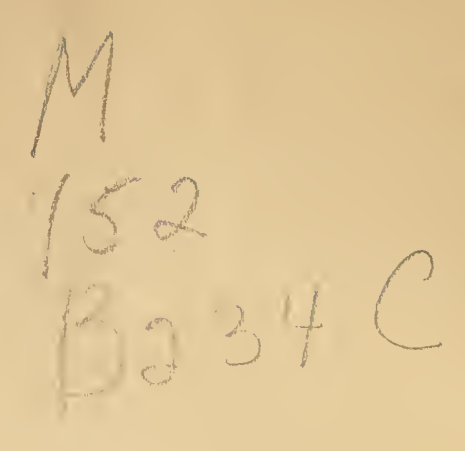

Tuner 1057 Ing Fund 324458 


\section{COMBINATIONS OF COLOURS WITH TINTS AND WITH SHADES}

The experiments reported in the following paper are a continuation and a natural supplement to those of Miss Baker and Miss Chown published in Volumes I and II. The former, Dr. Baker, has furnished most valuable results with regard to the colour harmony in binary combinations of colours of full saturation; and Miss Chown's investigation has given conclusive results with regard to the combinations of colourless light with the colours (full saturation, shades and tints). There remains then to investigate the harmony between the colours, on the one side, and the tints and shades on the other, and that between the tints and shades among themselves $\left(T_{2}\right.$ with $T_{2}$, $S_{2}$ with $S_{2}, S_{2}$ with $T_{2}$, and $T_{2}$ with $S_{2}$ ). The first half of this task, i.e., the harmony between the colours and the tints and shades, is our present subject.

The experiments under discussion here were conducted in the Psychological Laboratory of the University of Toronto. The room was lighted uniformly by skylight, and the judgments were made in the afternoons at about the same time, in order to secure equal light intensity, so that as far as possible the phenomenon of Purkinje might not affect the results. Other conditions of distance from, and angle with the table, etc., were kept as uniform as possible. Upon a table with a sloping top covered with black velvet the 24 combinations were arranged in two rows, I to I 2 and 24 to I 3 , no. 24 being under no. I. Each combination consisted of two coloured cards, $83 \times 33.5 \mathrm{~mm}$., one colour (or its shade or tint as the case might be) being the same (constant) in all of the 24 pairs displayed at one time, the other colour (or shade or tint), called the variable, being that corresponding to the number placed above it. These variables always formed a colour-circle in uninterrupted spectral order; the combinations were 100 $\mathrm{mm}$. apart. Thus it is seen that according to this method a constant would be combined with each of the 24 variables at each trial, and in a series of 24 each of the 24 constants would be combined with each of the 24 variables. 
There were ten observers, varying in age and of either sex. They were asked not to consult one another regarding their results, and also to make their judgments from the immediate impression of the combinations as free as possible from distracting associations of other shapes, sizes and uses that imagination might present. Each observer completed the whole four series and recorded the numbers of the combinations found agreeable. In a second and third column were recorded those found most agreeable and unpleasant respectively.

In all experiments the constant was placed at the left of the variable, and as cach constant appeared also as a variable at the right of its corresponding constant (previously a variable) each combination appears in both ways. Hence, as we combine our results the space-error is eliminated. To eliminate the time-error the order in which the constants were chosen was not that of the spectrum or any other, but they were selected at irregular intervals, so that the choices would not result from a similarity of the series with the one preceding.

Cohn used ro colours in his experiments, giving $\frac{\text { 1o } \times 9}{2}=45$ combinations. Miss Baker and also Miss MacDougall used 24 colours, giving $\frac{24 \times 23}{2}=276$ different pairs. Miss Chown used 24 colours with 5 greys and black and white, giving $24 \times 7=168$ combinations. In the present experiments the multiplier is not diminished by $\mathrm{x}$, as in Miss Baker's, on account of the colour with itself giving no binary combination. The colour with its own shade or tint gives a true combination; hence we have $24 \times 24=576$ in each of four series, or 2304 different combinations in all. As the number of observers is ro, and as each combination appears twice, therefore the number of judged combinations is $2304 \times 10 \times 24=46080$.

Tables I to IV give a condensed statement of the results. In the horizontal line of figures at the top of the table, and in the vertical line at the left, are the ordinals of the tints or shades and of the colours in full saturation, respectively. All the other numbers are cardinals, and each indicates how 
many times the particular colours and tints (or shades), indicated by the corresponding ordinals at the left and at the top, have been chosen. The columns at the bottom and at the right side of the tables give the totals for the tints (or shades) and for the colours respectively.

Tables $\mathrm{I}$ and II refer to combinations of colours and tints; Tables III and IV refer to combinations of colours and shades. Tâbles I and IIr report the "pleasant" and Tables II and IV the "most pleasant" combinations. "Unpleasant" judgments are not reported here although they are on record.

Since the tables are not easily surveyed it will be convenient to employ curves for the further discussion of the results. For this purpose a curve has been drawn for each colour, shade, and tint, analogous to those published by Miss Baker for the individual colours. Of these ninety-six diagrams we can give here only a few samples. Fig. I, for instance, deals with the combinations of colour 15 with the tints, while Fig. II refers to the combinations of tint 15 with all the colours. It may be mentioned that for other colours the difference between the curve for the colour in full saturation and that one for the tint differs sometimes more widely than in the present example. In a similar way Figs. III and IV give the curves for the combinations between colour 15 and the shades, and shade 15 and the colours. The upper curve always refers to the "pleasant," and the lower to the "most pleasant" combinations. In order to see what rôle complementarism plays in these combinations we have marked in these curves (as also in the later ones) the place of the complementary colours by a cross $(+)$.

In Figure I, and in the corresponding diagrams for the other colours, not published here, the ordinates of the curves are an indication of the frequency with which the fully saturated colour has been chosen in combination with the tints. In these diagrams we see, just as in Miss Baker's, the unmistakable peaks in the curves for red, indicating a preference for a certain region of the colour circle,turn, in the orange and yellow, into a more indifferent plateau-like series of smaller [169] 
BARber : Colours with Tints and Shades

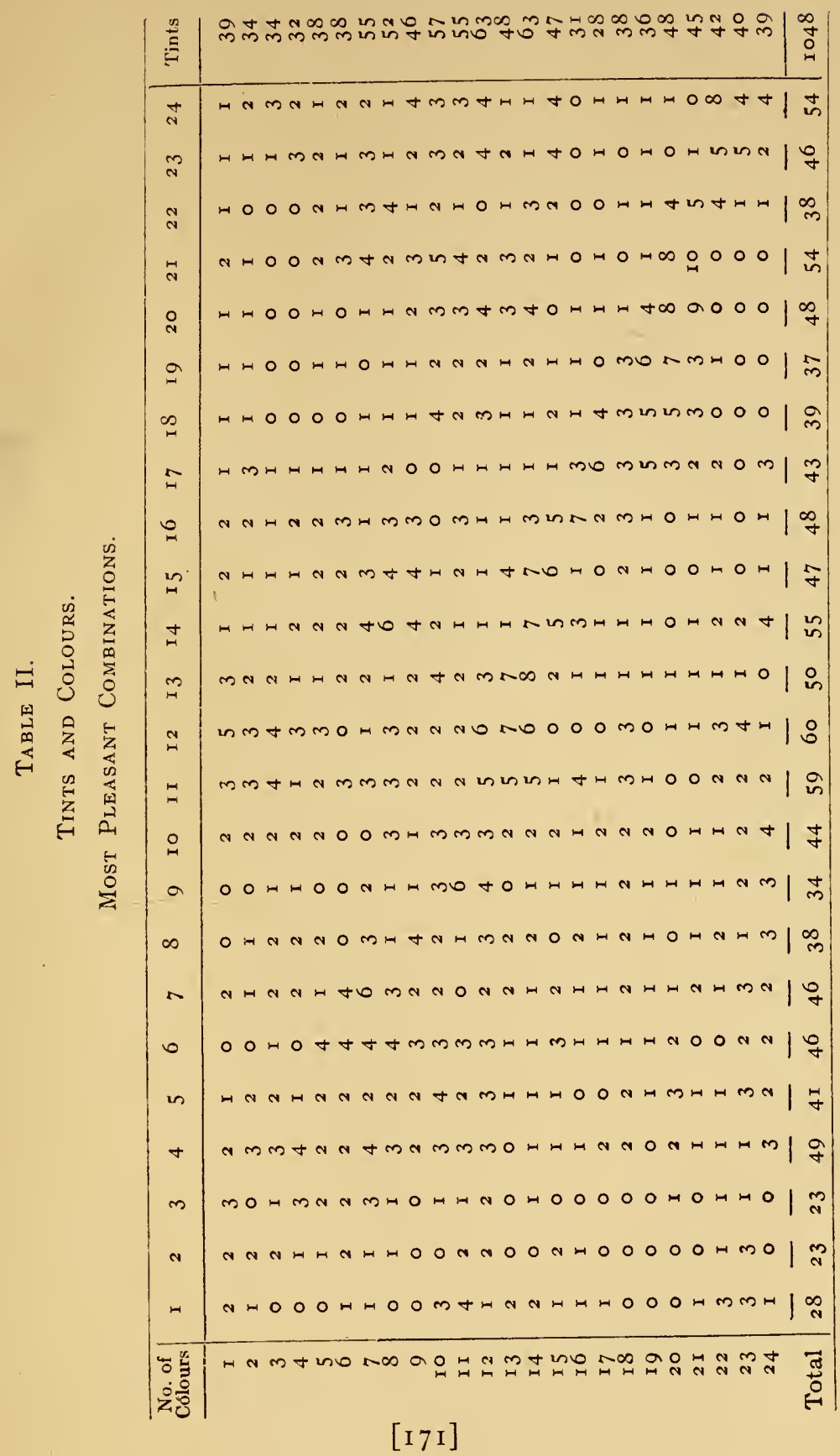




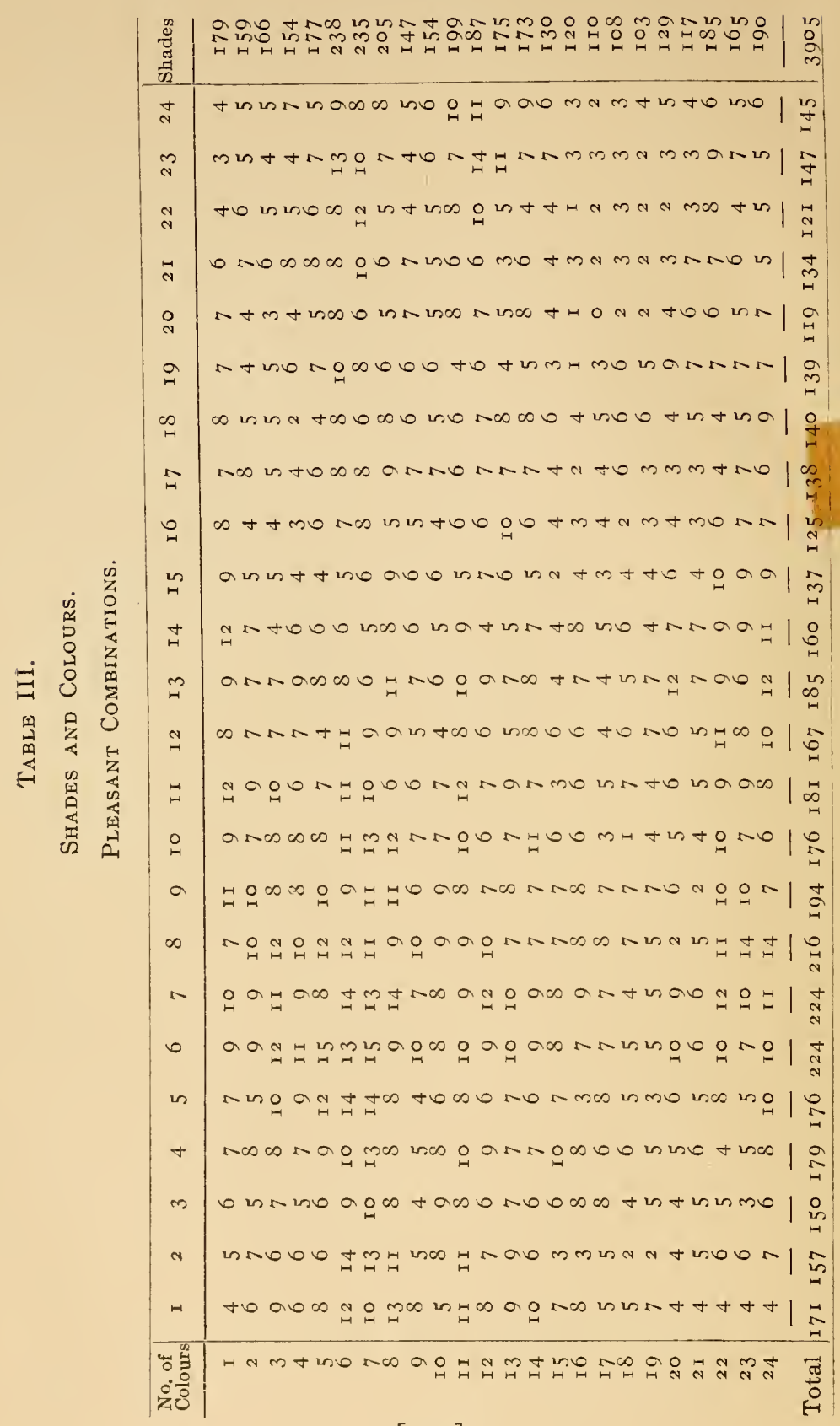
[1 72] 


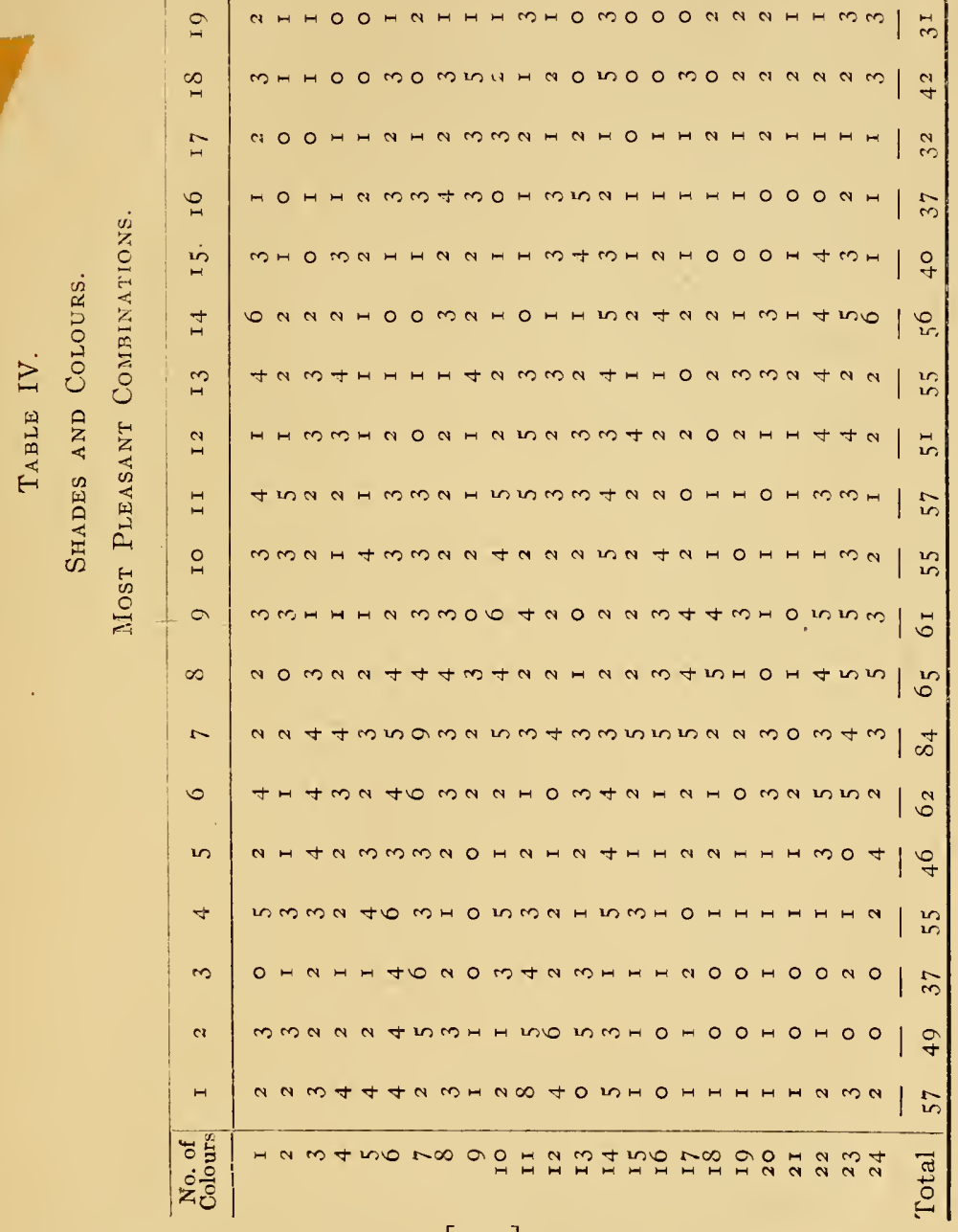

[I 73] 


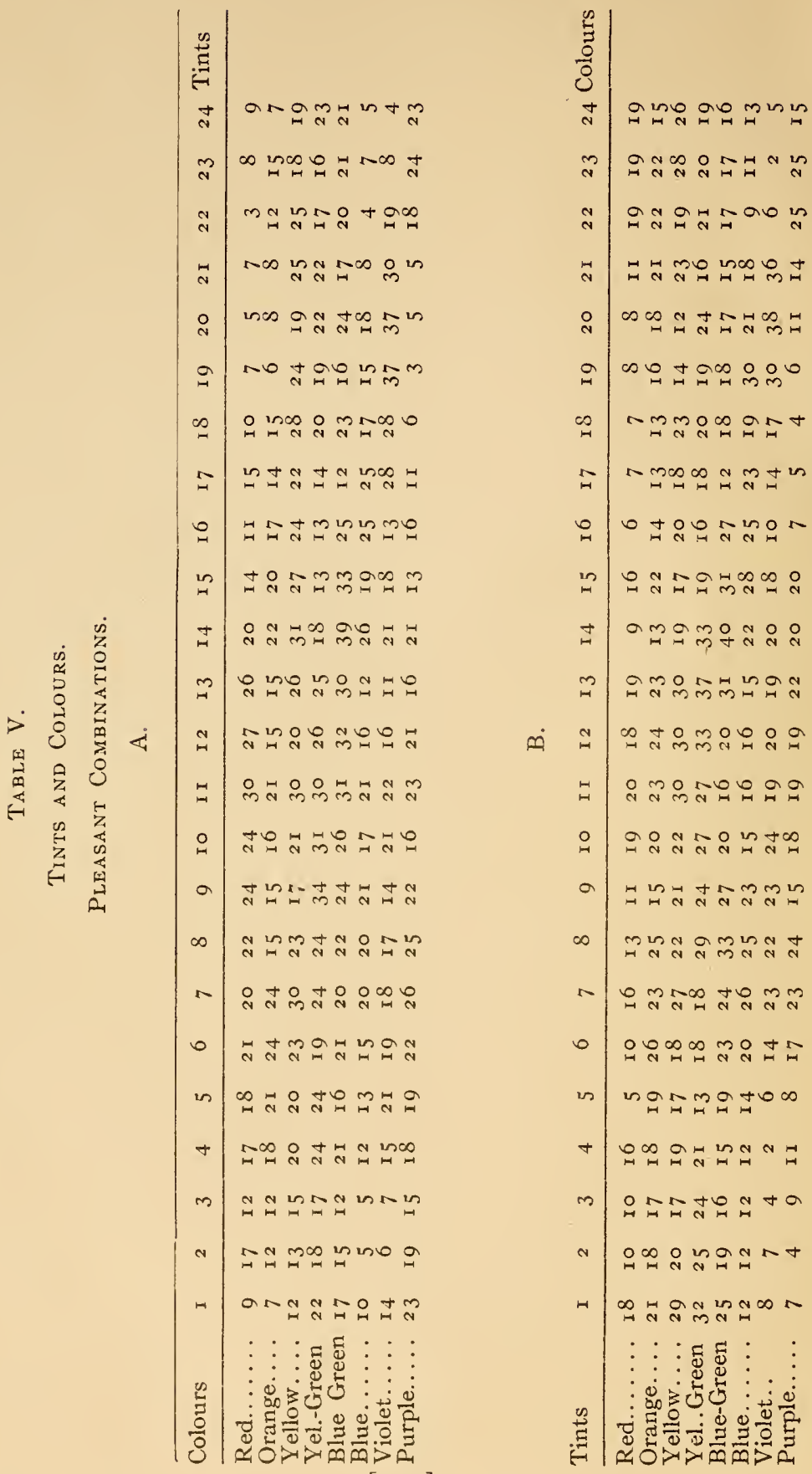




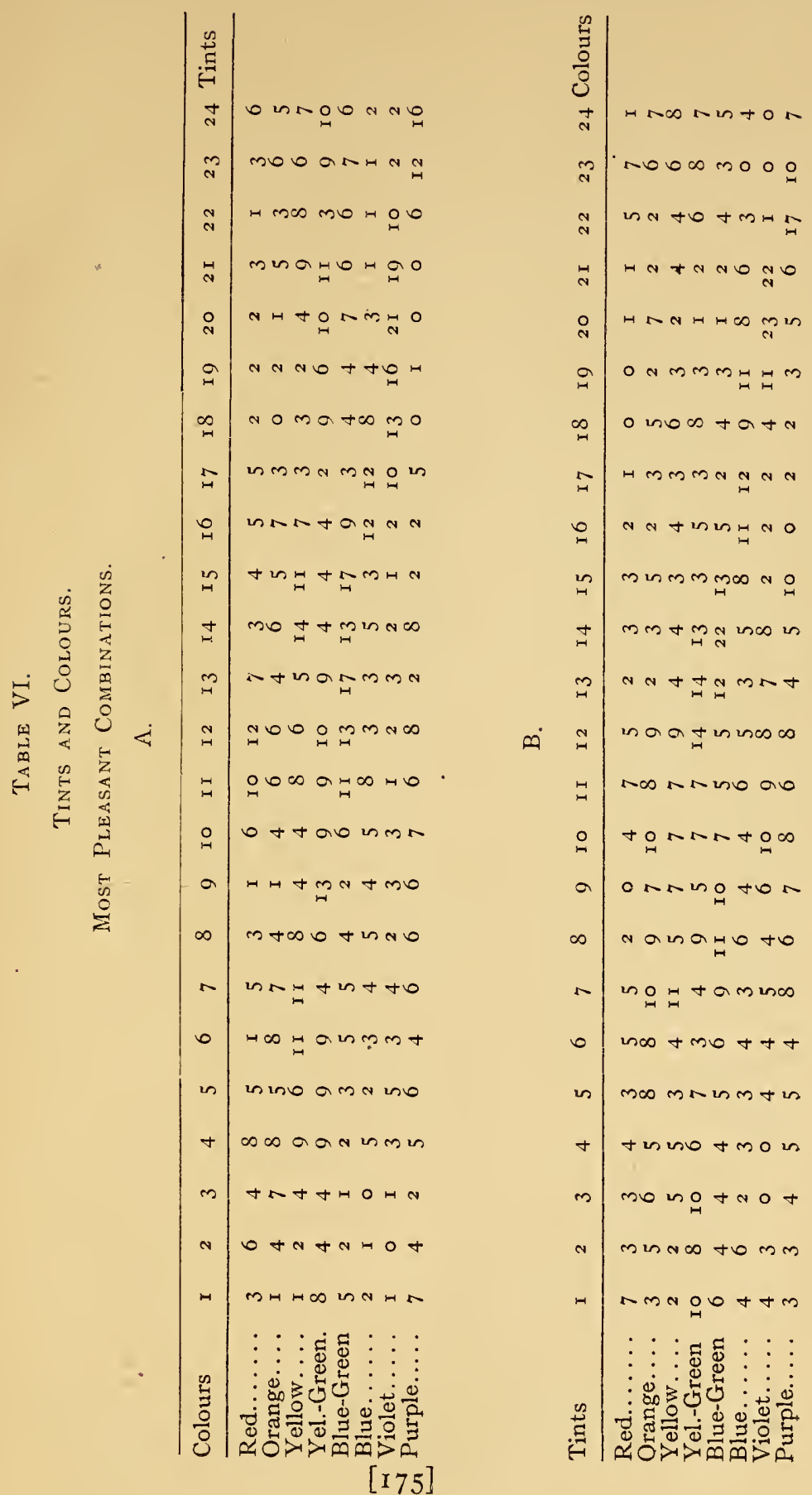




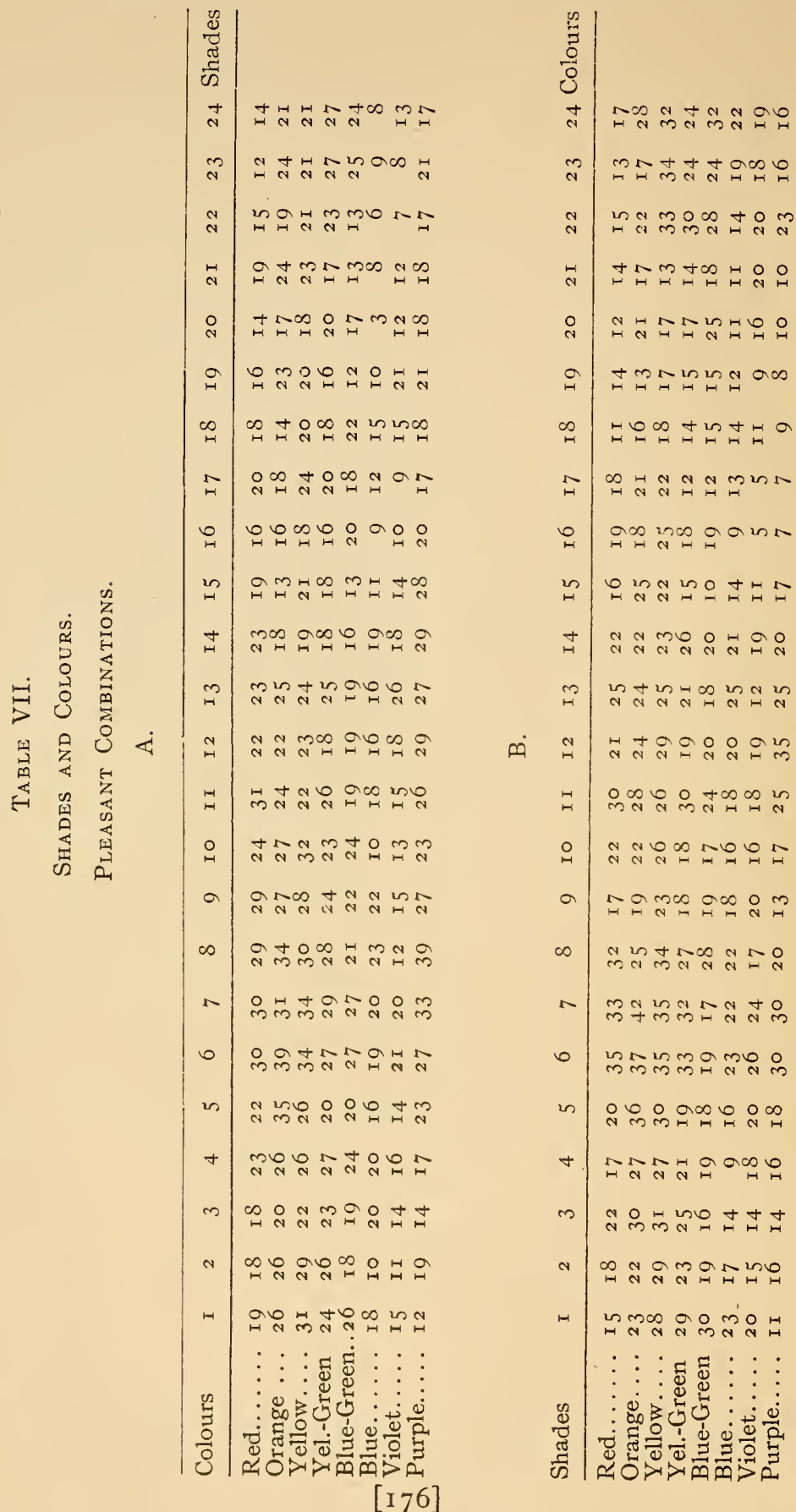




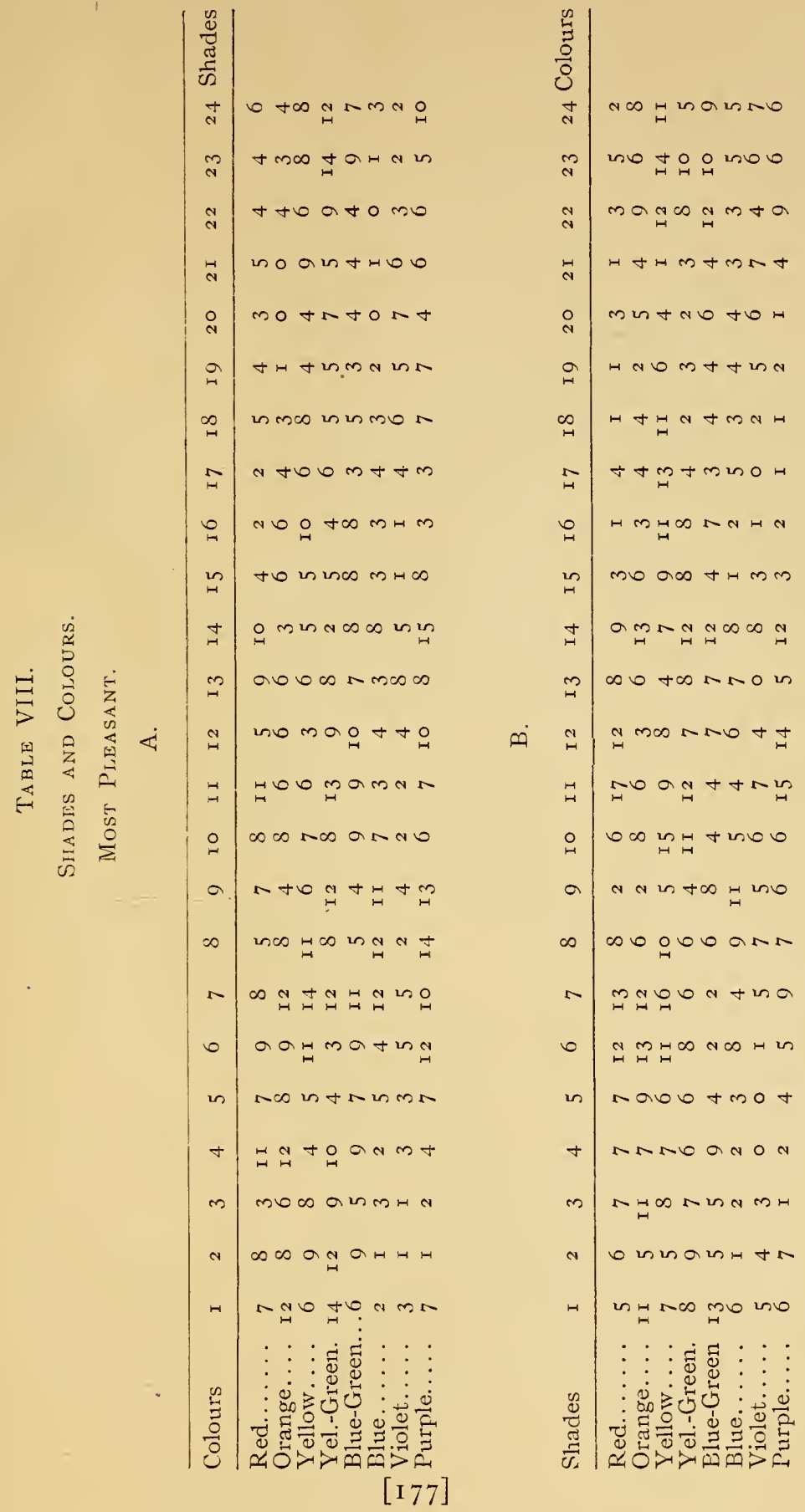


maxima distributed over the whole field. The maximum never coincides with the complementary colour. The latter is sometimes even very near the minimum. But in a few cases also it is at a minor maximum.

In one sense the curves are not comparable with those of Miss Baker's, where the colour could never be combined with itself, whilst in our experiments the colour combined with a shade or a tint of itself might make a very good combination. So we see, for instance, that the purples and reddish-purples, which, as everybody knows, are so difficult to match, have their maximum with themselves or their nearest neighbours, and a second maximum with yellow or greenish-yellow. Of course, Miss Baker's curves could show no such thing, as the colours combined with themselves would make no binary combination at all.

In the curves of which Figure II is a sample the frequency of the selection of a tint with the colours is shown. Of course, it must by no means be expected that the curves closely correspond to those of the foregoing series-though they may show similar features, in so far as the colour quality is concerned. Thus, for instance, we make the same observation as regards the non-coincidence of maximum and complementary, and we observe again the above mentioned relations of the purple with itself and yellow.

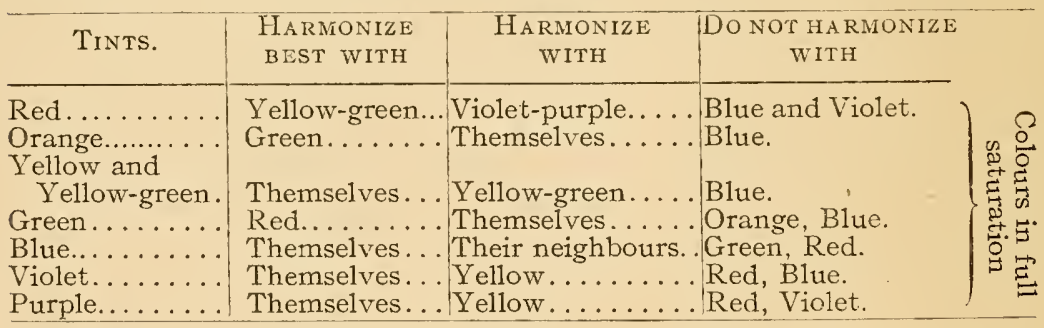

The third series of curves of which Figure III is a specinen shows the harmonic qualities of colours in relation to the shades. Complementarism does not seem to be favoured except in the green and the blue, and partially so in the purple. Here there are sometimes several maxima, which for the red colour [178] 
are always in the yellow or yellow-green. The orange and yellow colours have their maxima decidedly with their own shades or with those of near neighbours-a circumstance which might well be expected from the frequency with which, for ornamental purposes in rooms, architecture, etc., we use the combinations of different shades of yellow or orange (brown). As soon as we come toward the green, however, the maximum jumps to the purple, and for the colours $I_{2}$ and $I_{3}$ we have the rare case where the maximum closely coincides with the complementary. Thus, while complementary green and purple do not form the most agreeable combination when in full saturation, ${ }^{1}$ they do so when the purple is a shade. Similarly we find a maximum for the purple colours $(22,23,24)$ in the green ( I I, I 2, 13), though in this case the yellow has still a little greater preference. While we observed that the purple colours harmonize very well with their own tints, we cannot say the same with regard to their relation to their own shades; on, the contrary, their own shades are decidedly in the minimum.

Figure IV is an example of the fourth set of curves which indicate the frequency with which the shades were chosen in combination with the colours. Here we make the same observations with regard to the green. It seems to harmonize best with the purple, though in no case is the complementary directly in the maximum. The maxima fall as follows :-

$\begin{array}{lll}\text { Red } & \text { with } & \text { Yellow } \\ \text { Orange (Or.-Yellow) } & \text { “ } & \text { Orange-Yellow. } \\ \text { Yellow } & \text { “ } & \text { Purple and Orange. } \\ \text { Yellow-green } & \text { “ } & \text { Orange-yellow. } \\ \text { Bluish-green } & \text { “ } & \text { Purple. } \\ \text { Green } & \text { “range-yellow and Purple. } \\ \text { Blue } & & \begin{array}{l}\text { Yellow and Green, and the } \\ \text { minimum with itself. }\end{array} \\ \text { Violet } & \text { “ } & \text { Violet-purple and Yellow. } \\ \text { Purple } & \text { “ } & \text { Yellow and Green. }\end{array}$

1 See Miss Baker's Curves. 
What has been stated with reference to the 96 curves of which we could only give four examples will appear equally clear in the following plates, containing Figures $\mathrm{V}$ to XX.

These curves correspond to some extent to the combination curves XXV to XXXVI in Miss Baker's first article. In these curves three qualities ate always combined, thus, Red stands for one, two and three, Orange for four, five and six, Yellow for seven, eight and nine, Yellow-green for ten, eleven and twelve, Blue-green for thirteen, fourteen and fifteen, Blue for sixteen, seventeen and eighteen, Violet for nineteen, twenty and twenty-one, Purple for twenty-two, twenty-three and twenty-four. The numbers for the ordinates of these curves will be found in Tables v, vi, vii and viii.

Each figure contains four curves, the upper referring to "pleasant" and the lower to "most pleasant" combinations. In Figure $\mathrm{V}$ the plain curves refer to the combinations of the tints with the fully saturated red $(1,2,3)$; the dotted curves on the other hand represent the combinations of the fully saturated colours with the tint of red $(1,2,3)$. The other figures are arranged similarly.

Figures XXI and XXII give the grand total or summation curves. In the former the results of the combinations of colours and tints are represented, whilst the latter refeis to colours and shades. Analogous to the foregoing figures the plain curves show the degree of harmonizing power of the colours in full saturation, whilst the dotted curves indicate the harmonizing capability of the shades and tints. In these curves the striking difference in the behaviour of shades and tints manifests itself at once. For combinations of tints and colours there is a broad maximum in the middle of the spectrum, in the yellow, yellow-green and blue-green. From there the harmonizing power of the tints slopes more or less abruptly down toward the spectral ends, whilst for the colours in combination with tints there are secondary maxima in violet and red, thus leaving the orange and the blue in a decided, and the purple in a less pronounced minimum. The 
curve for the "most pleasant" combinations forms in each case almost a copy of that for the pleasant on a smaller scale.

The pleasant curves for the "shades and colours" show a most decided maximum in the orange-yellow and secondary maxima in the green and purple. The deepest drop appears in the blue and violet. This minimum and the secondary maxima are more pronounced for the colours than for the shades. The "most pleasant" curve corresponds well with the "pleasant" in case of the shades, whilst for the colours there are three pointed maxima in the orange-yellow, the yellow-green and the blue-green, the latter being the highest, with decided drops between them.

The summation curves as well as the grand totals of Tables $i$ to iv show that in combination with fully saturated colours shades have a considerable advantage over tints. The pleasant combinations of shades and colours exceed those of tints and colours by 373 which is about ro per cent., whilst for the most pleasant combinations a corresponding excess of 123 is observed, which amounts to almost I 2 per cent.

In Tables $\mathrm{ix}, \mathrm{x}, \mathrm{xi}$, xii we give a more condensed and consequently a more perspicuous representation of our results. The grouping together of three consecutive qualities is applied here to both sides,- to the colours as well as to the tints and shades. Hence it is quite easy to survey the 64 fields of the tables. Thus, for instance, in Table ix the first horizontal row. of numbers indicates that the power of harmonization of red with the tints of the eight qualities is greatest for yellowgreen, less great for yellow and for blue-green, still less for orange, red, blue and purple and smailest for violet.

The first vertical column, on the other hand, shows that the tint of red when combined with the colours in full saturation harmonizes equally well with yellow-green and purple, somewhat less with blue-green, yellow and red, still less with orange and violet and least with blue. So with the other columns. From the whole table one can see that with regard to the combination of tints and colours the gravitation of pleasantness is to the middle of the spectrum; whilst from Table [I $8 \mathrm{I}]$ 
xi it can easily be deduced that the gravity centre for pleasantness for shades and colours is decidedly with the "warm" colours (orange and yellow). The question in how far the colours agree with their own tints and shades can also be settled by these tables., The best to agree with their own tints, as Table ix shows, are blue-green and violet, next comes yellow-green, then yellow, blue, purple, and the least, red. A glance at Table $\mathrm{x}$ shows that the same result can be ascertained from the "most pleasant" judgments. Tables xi and xii show that it is quite different with regard to shades. The colours which agree best with their own shades are orange and yellow. 
TABLE IX.

Tints and Colours.- "Pleasant."

Colours. R. Or. Y. Y.G. B. B.G. V. P. Tints.

\begin{tabular}{|c|c|c|c|c|c|c|c|c|c|}
\hline R... & ${ }_{3} 8$ & $5^{6}$ & 66 & $8 x$ & 60 & $3^{6}$ & I 9 & 20 & 376 \\
\hline Or. . & $3 \mathrm{I}$ & $6_{3}$ & 54 & $5^{2}$ & 57 & 46 & 22 & $3^{6}$ & $36 x$ \\
\hline $\mathrm{Y} \ldots .$. & 40 & $6_{3}$ & 70 & 71 & 84 & 74 & 68 & 62 & $53^{2}$ \\
\hline Y.G... & 57 & 67 & $8 z$ & $8_{7}$ & $5^{6}$ & 47 & 63 & $5^{6}$ & $5^{\times} 5$ \\
\hline B.G.. & 44 & $5^{8}$ & 66 & 89 & 102 & 60 & 57 & 62 & $53^{8}$ \\
\hline B.. & 20 & 40 & $6 I$ & 54 & 57 & 67 & $4 \mathrm{x}$ & x 6 & $35^{6}$ \\
\hline V.. & 27 & 55 & 49 & 59 & $5^{\circ}$ & 69 & $\mathrm{IO}_{4}$ & $3 x$ & 444 \\
\hline & 57 & 59 & 73 & 60 & $5^{\circ}$ & 33 & $x_{3}$ & 65 & 410 \\
\hline & $3^{\mathrm{I} 4}$ & $46 I$ & $52 \mathrm{I}$ & 553 & $5^{16}$ & 432 & $3^{87}$ & 348 & $353^{2}$ \\
\hline
\end{tabular}

Table X.

Tints and Colours.- - Most Pleasant."

Colours. R. Or. Y. Y.G. B.G. B. V. P. Tints.

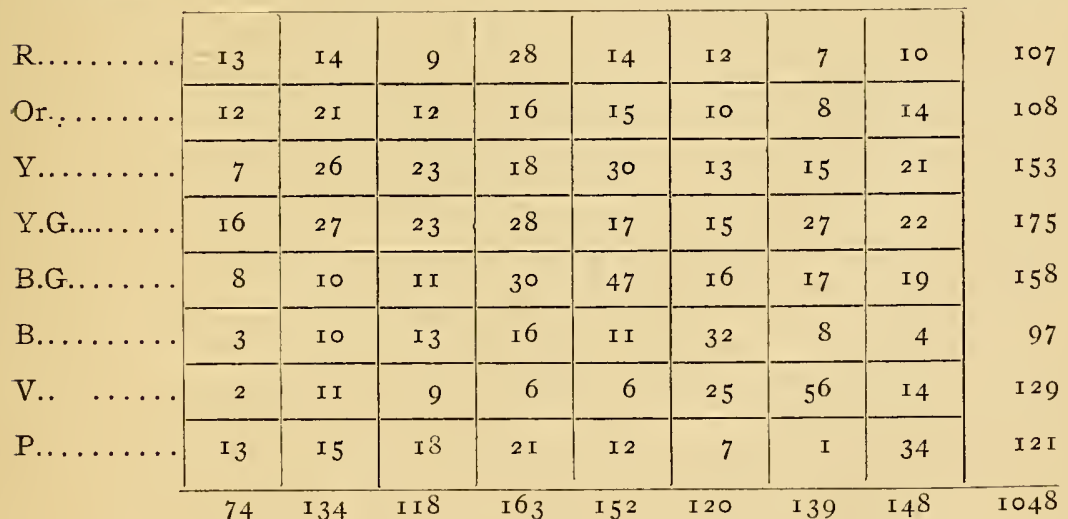


TABLE XI.

Shades and Colours.- " Pleasant."

Colours. R. Or. Y Y.G. B.G. B. V. P. Shades

\begin{tabular}{|c|c|c|c|c|c|c|c|c|}
\hline R........ & 55 & 75 & 88 & 77 & 65 & 54 & 49 & $4 \mathrm{I}$ \\
\hline Or..... & 72 & 100 & $9^{2}$ & 73 & $5^{6}$ & 48 & 64 & 64 \\
\hline Y..... & 82 & 86 & 92 & 77 & 64 & 62 & $6 I$ & $6_{3}$ \\
\hline Y.G...... & 73 & 74 & $8 I$ & 67 & $6 I$ & 54 & 53 & 77 \\
\hline B.G. . & 63 & $7 \mathrm{I}$ & 70 & 62 & 48 & 60 & 42 & 62 \\
\hline B.. & 48 & 55 & 65 & 44 & 46 & $3^{6}$ & $2 \mathrm{I}$ & 23 \\
\hline V... & 40 & $5 \mathrm{I}$ & 47 & $4^{6}$ & 58 & 34 & 45 & 28 \\
\hline P... & 45 & 67 & 99 & 78 & 84 & 55 & 57 & 55 \\
\hline
\end{tabular}

TABLE XII.

Shades and Colours.-_" Most Pleasant."

Colours. R. Or. Y. Y.G. B.G. B. V. P. Shades

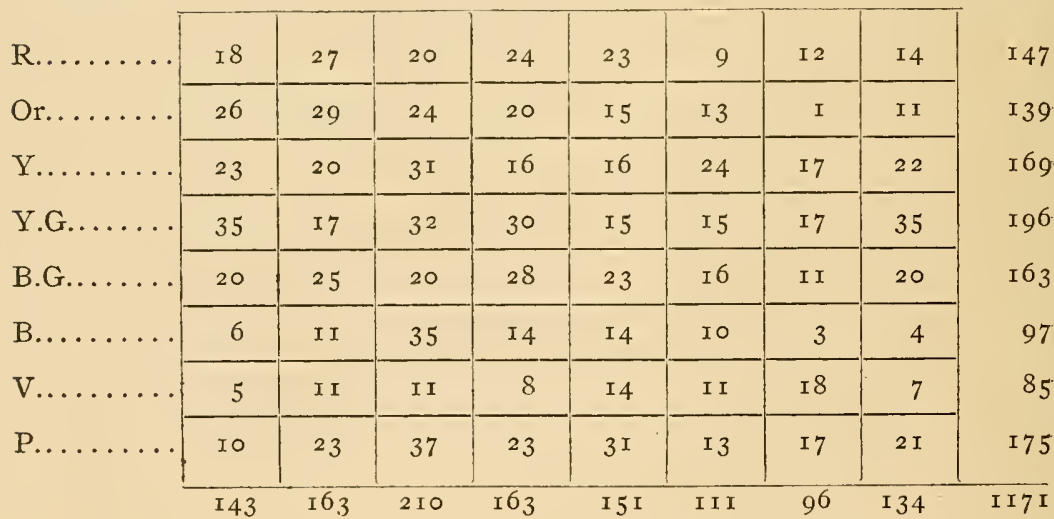





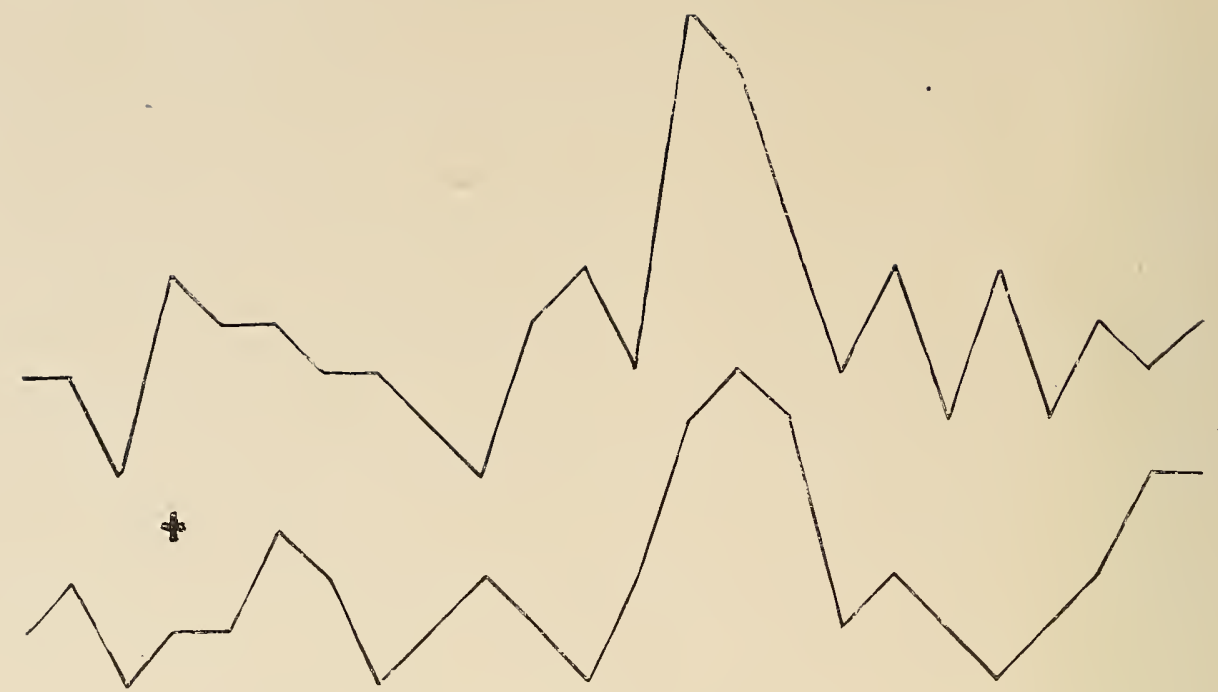

$\begin{array}{lllllllllllllllllllllllll}1 & 2 & 3 & 4 & 5 & 6 & 7 & 8 & 4 & 10 & 11 & 12 & 1 & 3 & 14 & 15 & 16 & 17 & 18 & 19 & 20 & 21 & 22 & 23 & 24\end{array}$ Tig. 1.-COLOUR I 5 With TIN.TS

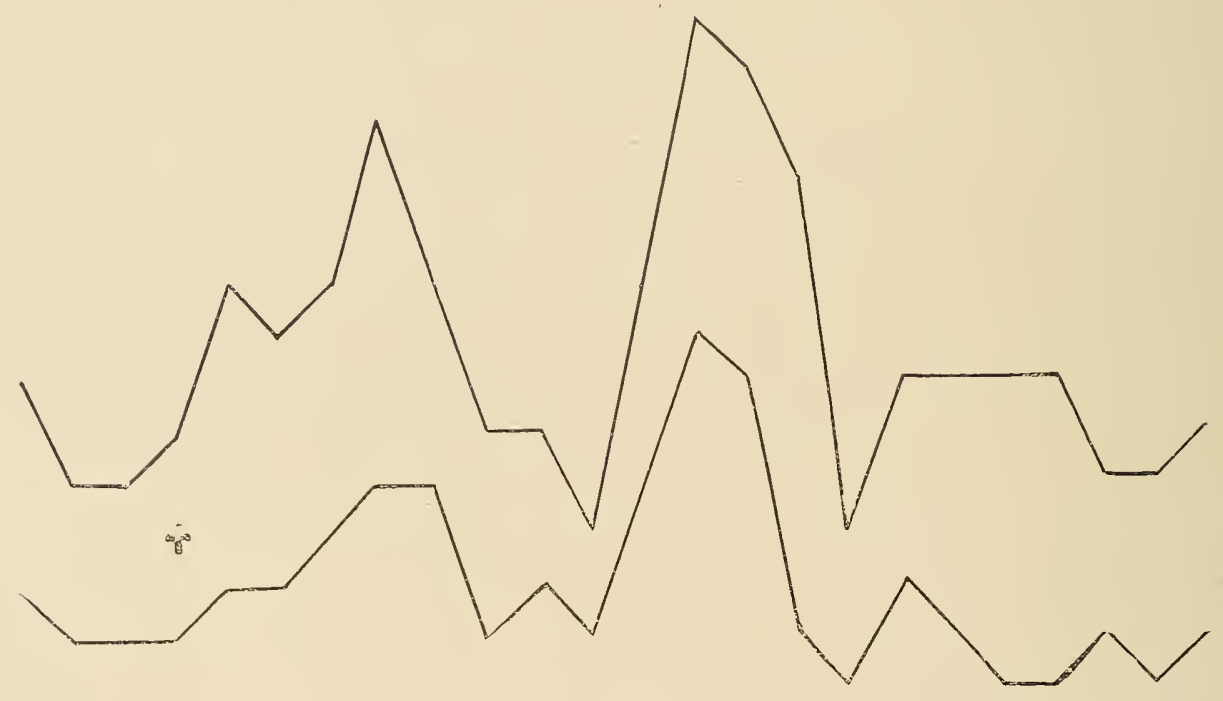

$\begin{array}{lllllllllllllllllllllllll}1 & 2 & 3 & 4 & 5 & 6 & 7 & 8 & 9 & 10 & 11 & 12 & 13 & 14 & 15 & 10 & 17 & 18 & 19 & 20 & 21 & 22 & 23 & 24\end{array}$ FIG. II.-TINT I 5 WITH COLOURS 


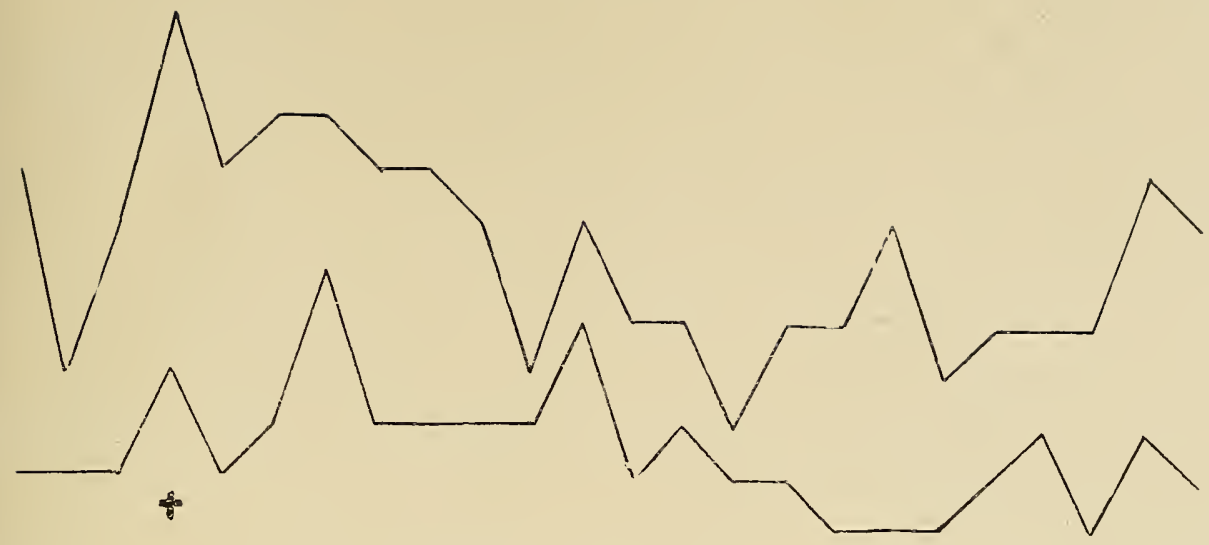

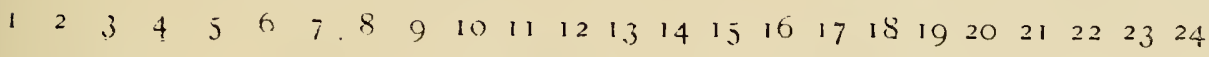
Fig. III.-Colour i 5 With Shades

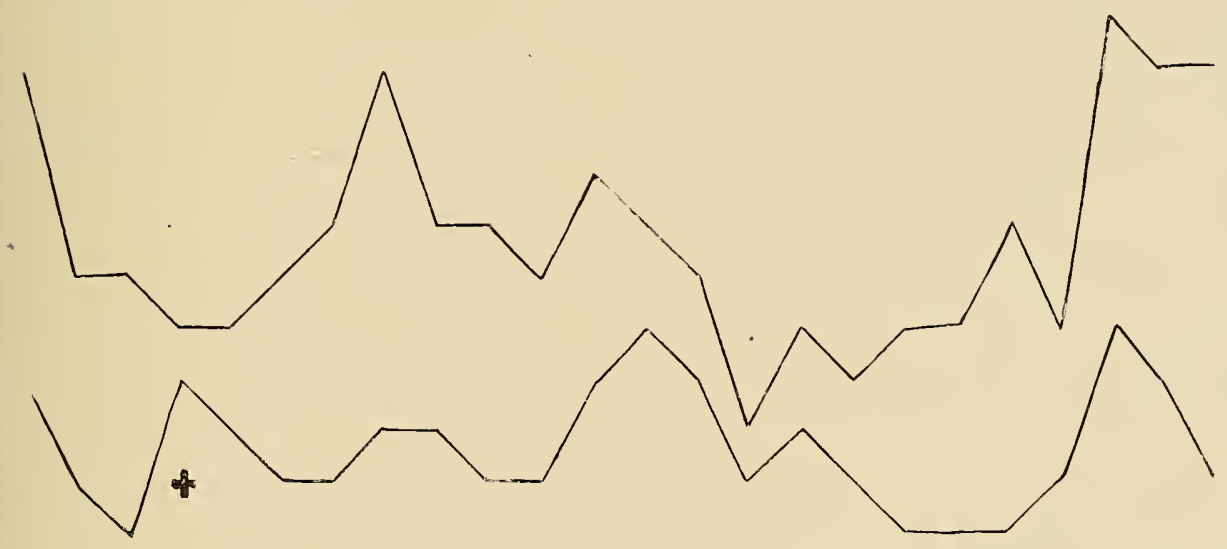

$\begin{array}{lllllllllllllllllllllllll}1 & 2 & 3 & 4 & 5 & 6 & 7 & 8 & 9 & 10 & 11 & 12 & 13 & 14 & 15 & 16 & 17 & 18 & 19 & 20 & 21 & 22 & 23 & 24\end{array}$ Fig. IV.--Shade I 5 WiTh COLOURS 


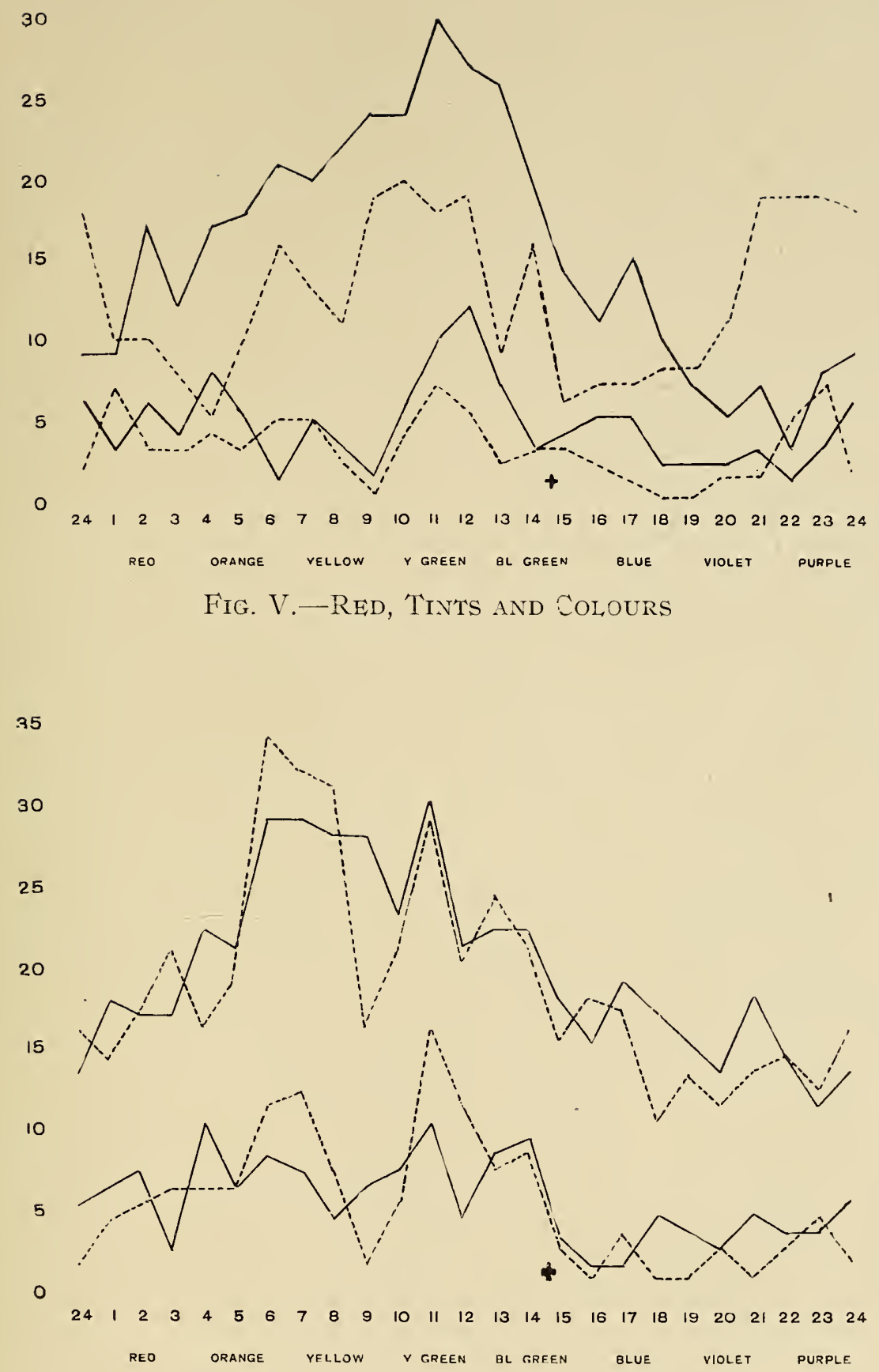

Fig. VI.-Red, Shades and Colours 



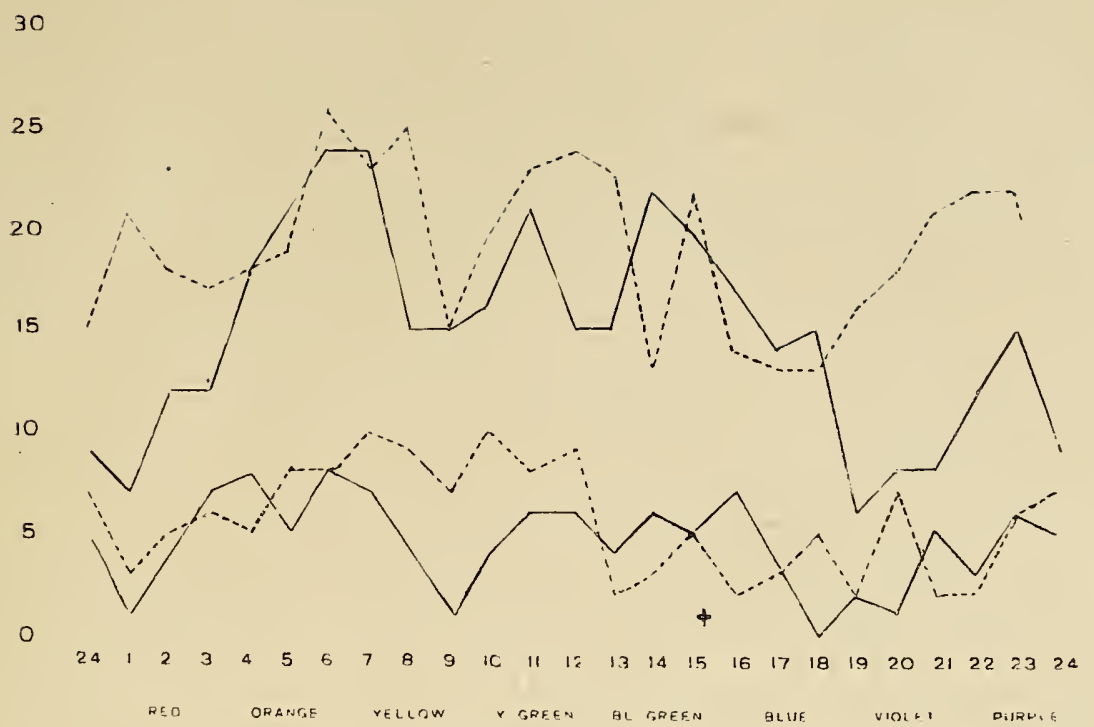

Fig. VII.-Orange, Tints And Colours

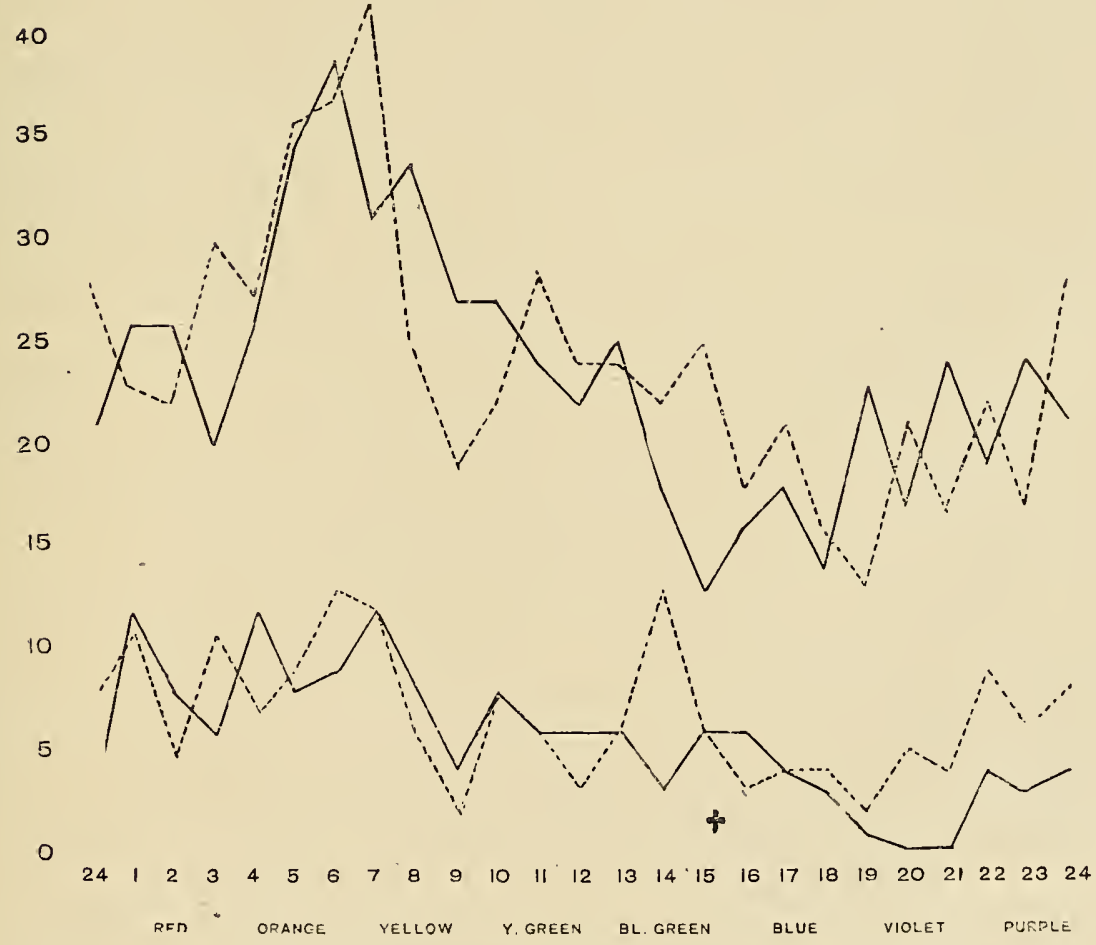

Fig. Viil.--Orange, Shades and Colours 



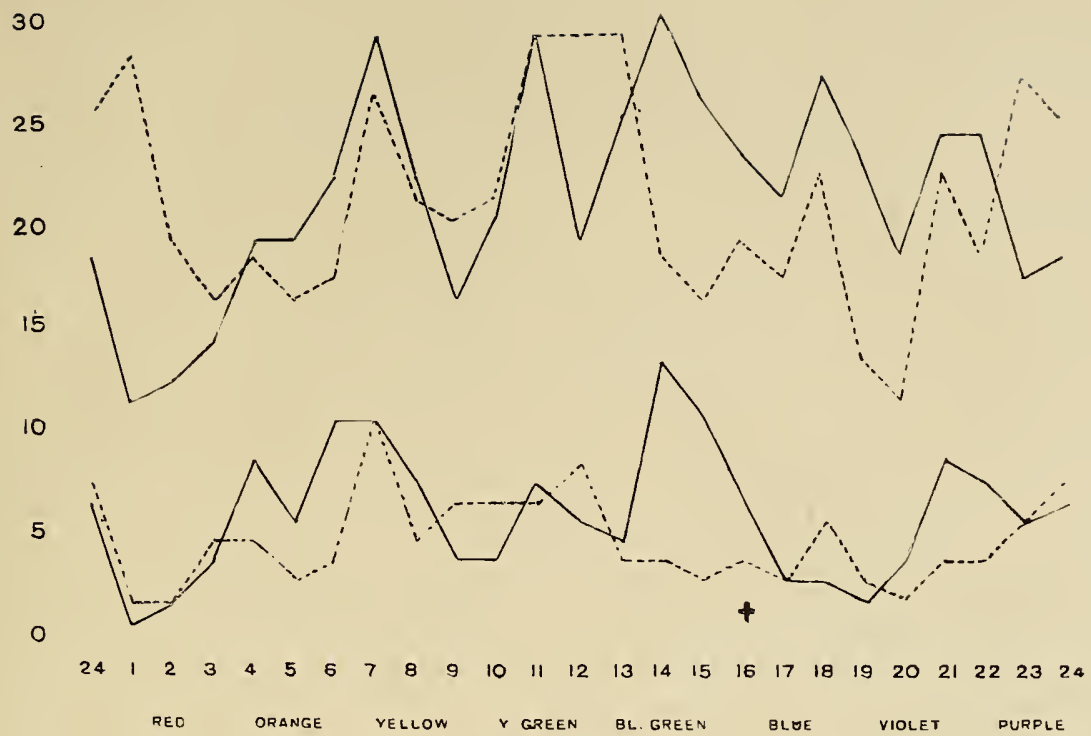

Fig. IX.-Yellow, Tints and Colours

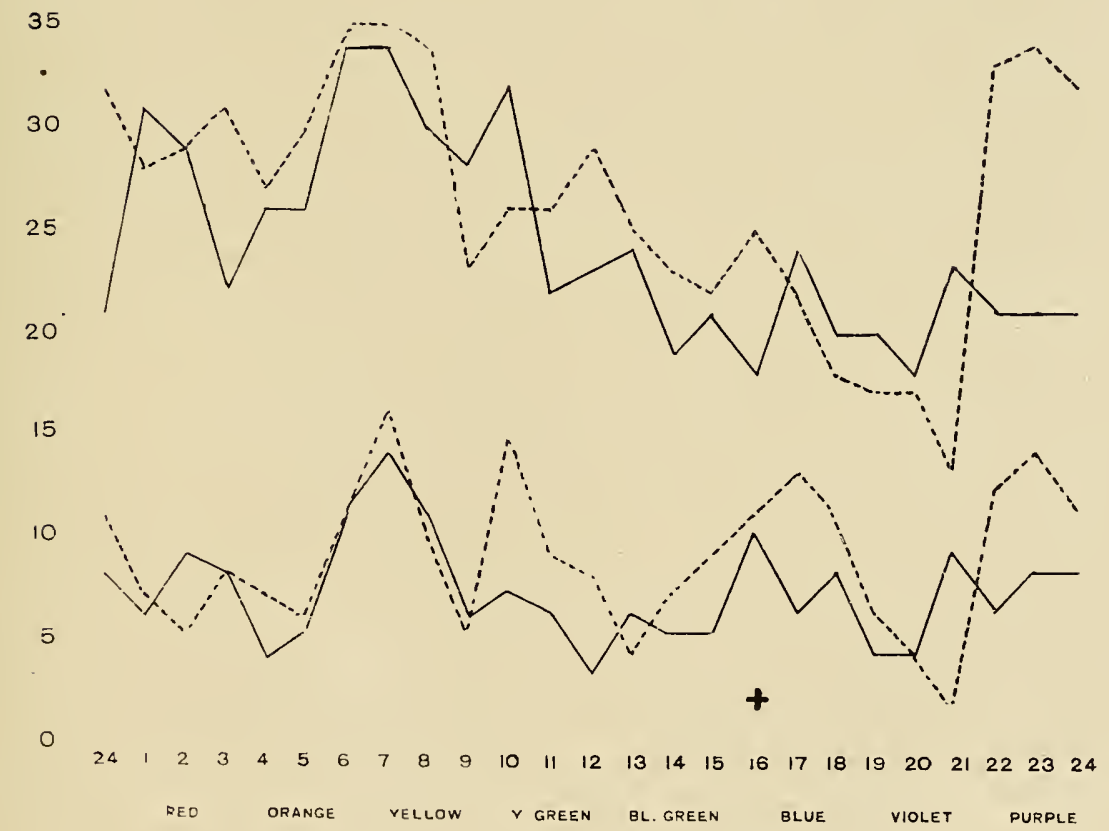

Fig. X.-Yellow, Shades and Colours 



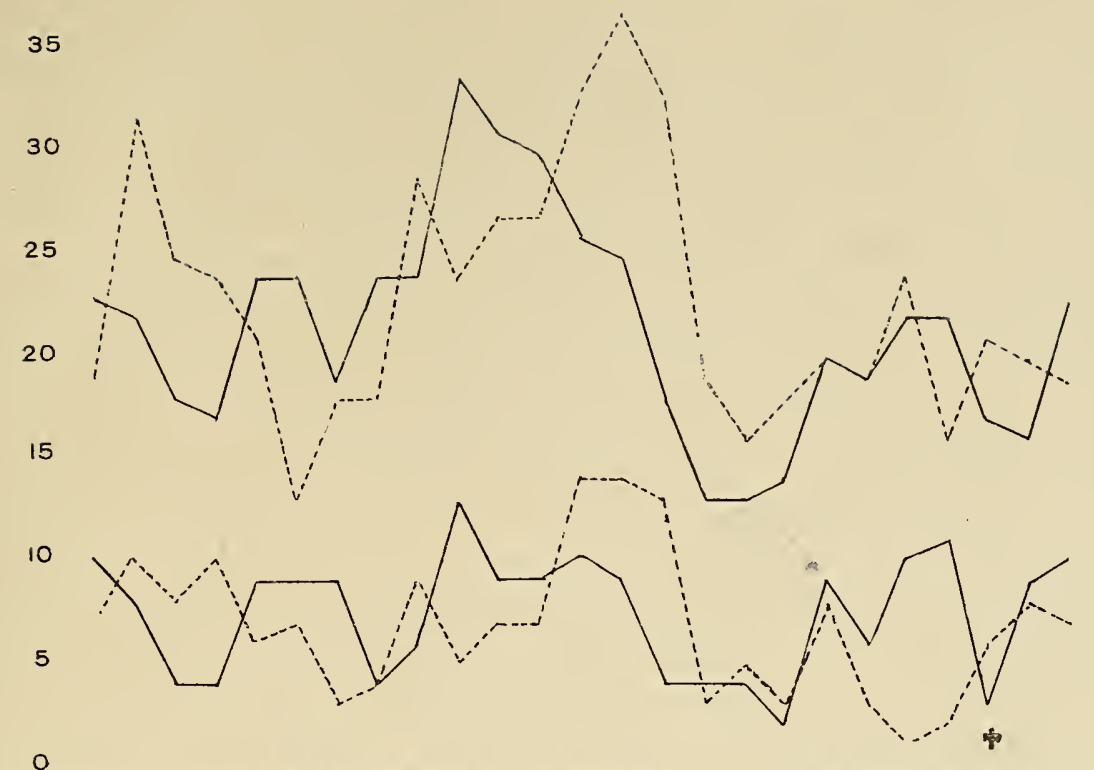

$\begin{array}{llllllllllllllllllllllllll}24 & 1 & 2 & 3 & 4 & 5 & 6 & 7 & 8 & 9 & 10 & 11 & 12 & 13 & 14 & 15 & 16 & 17 & 18 & 19 & 20 & 21 & 22 & 23 & 24\end{array}$ REO ORANGE YElLOW Y.GREEN BL GREEN BLUE VIOLET PURPLE

Fig. Xi.-Yellow-Green, Tints and Colours

35

30

25

20

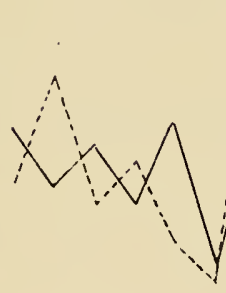

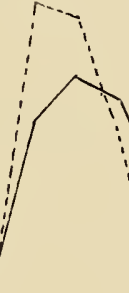

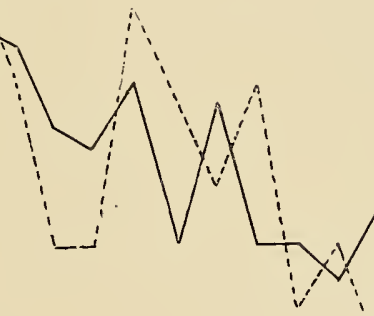

15
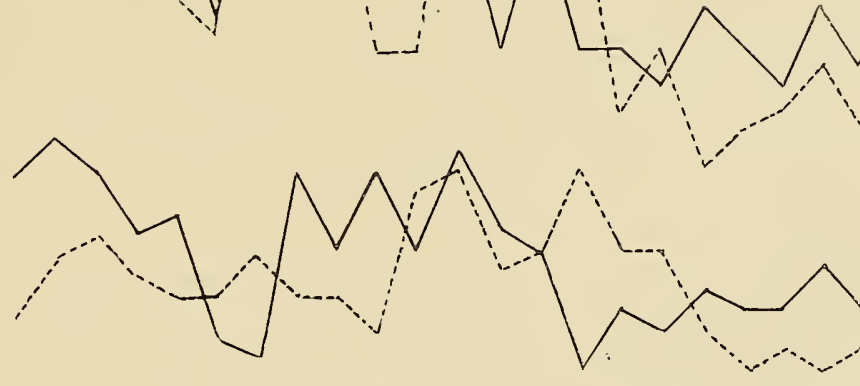

. 



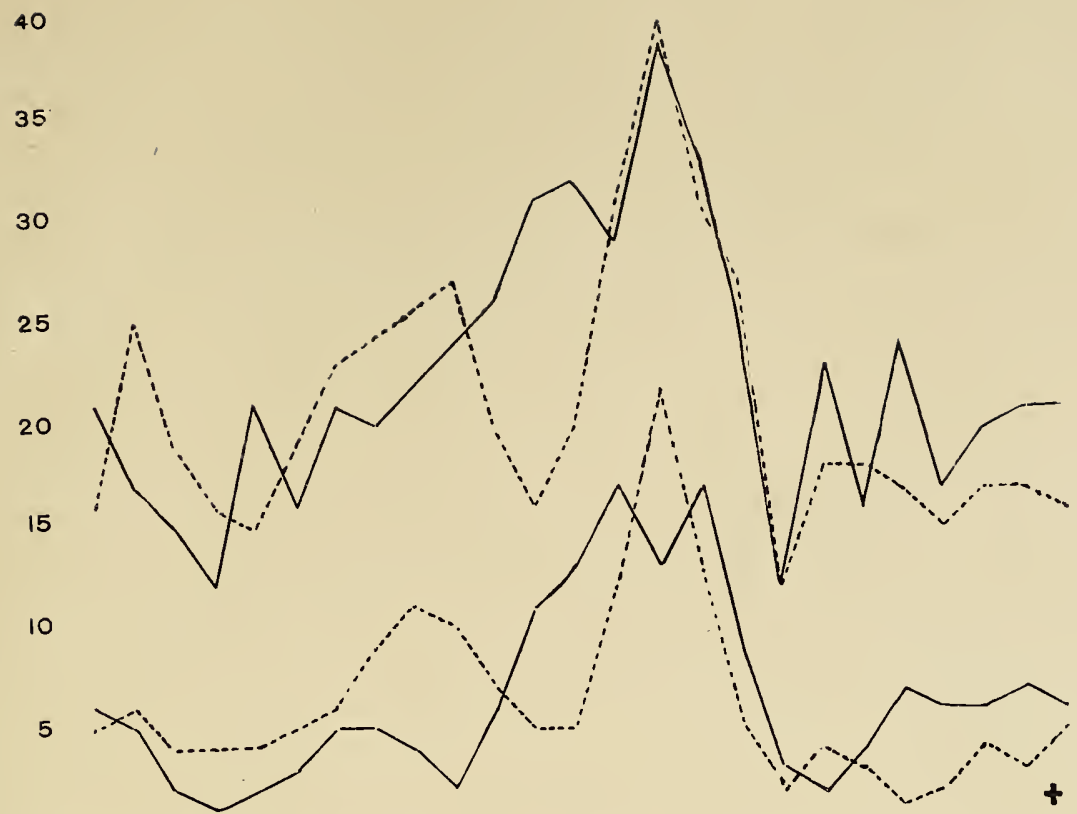

0

$\begin{array}{lllllllllllllllllllllllll}24 & 1 & 2 & 3 & 4 & 5 & 6 & 7 & 8 & 9 & 10 & 11 & 12 & 13 & 14 & 15 & 16 & 17 & 18 & 19 & 20 & 21 & 22 & 23 & 24\end{array}$

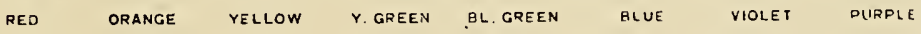

Fig. XIII.-Blue-Green, Tints and Colours

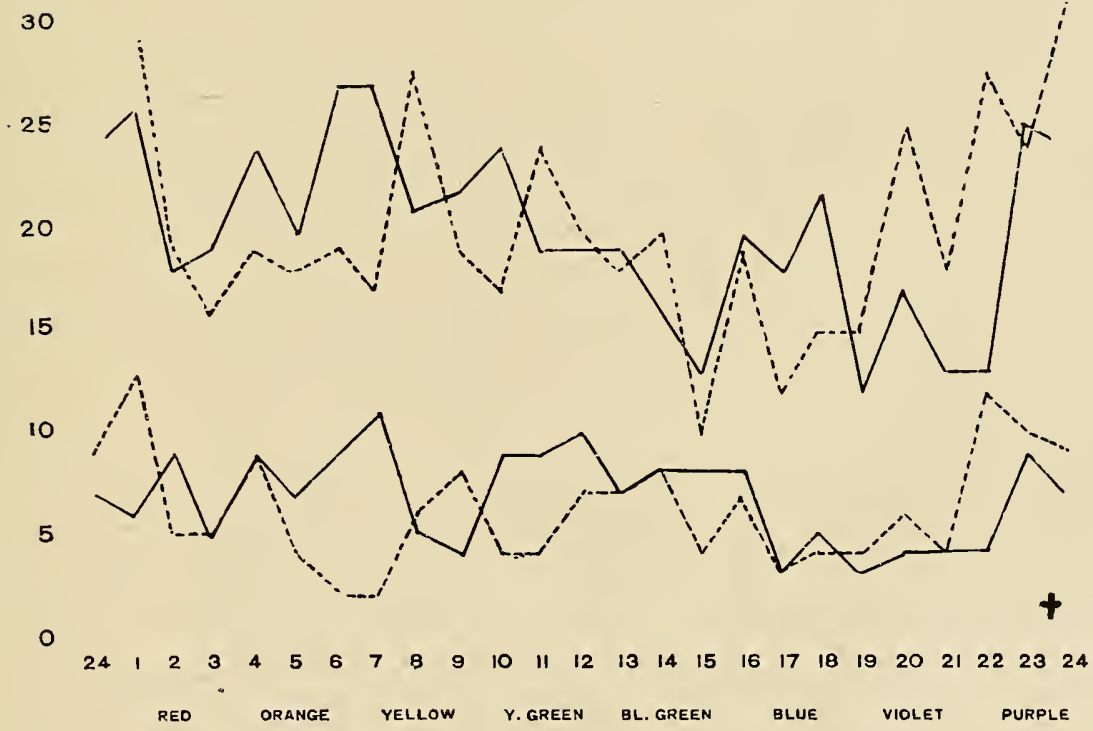

Fig. XIV.-Blue-Green, Shades and Colours 



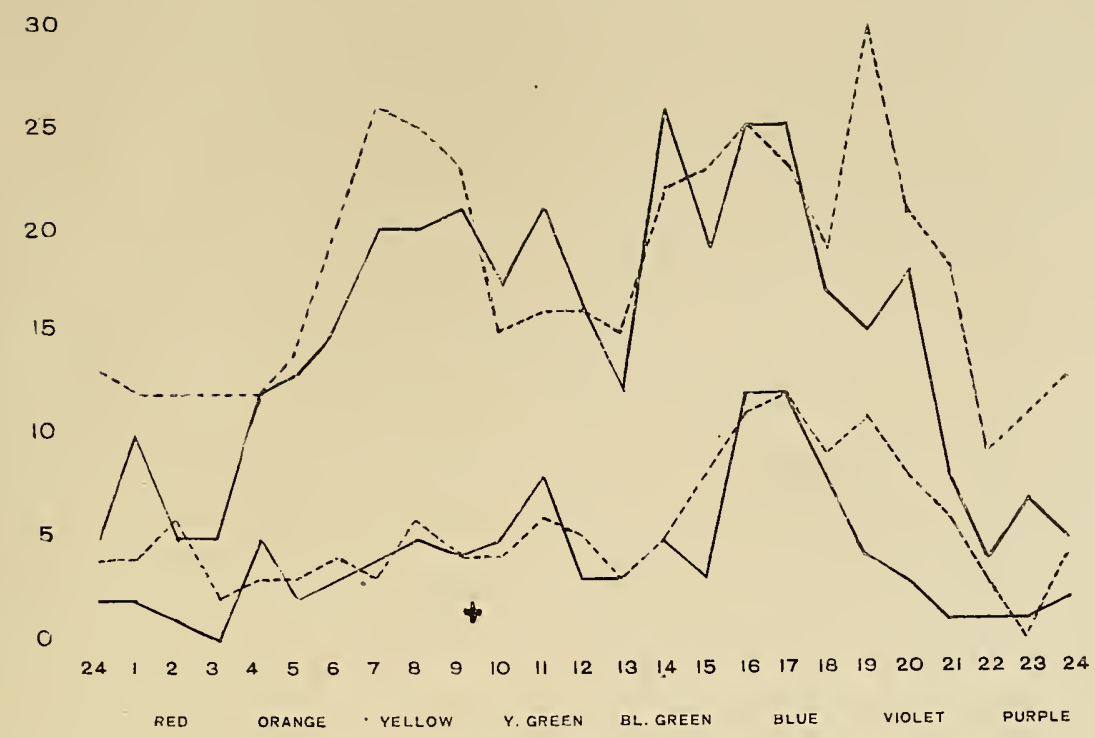

Fig. YV.-Blue, Tints and Colours

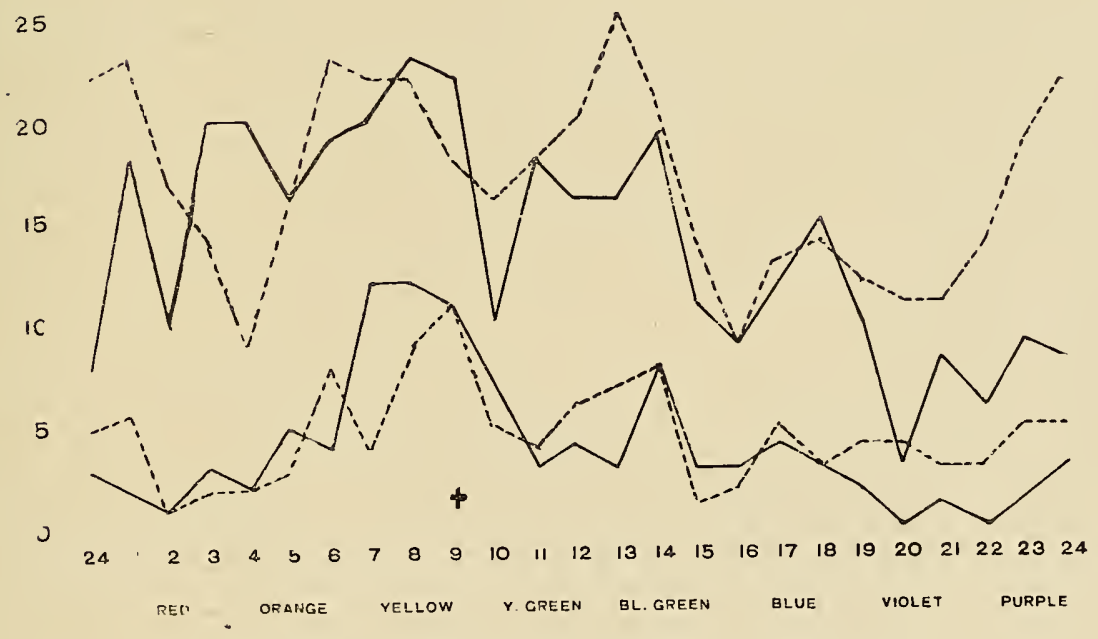

Fig. XVi.-Blue, Shades and Colours 



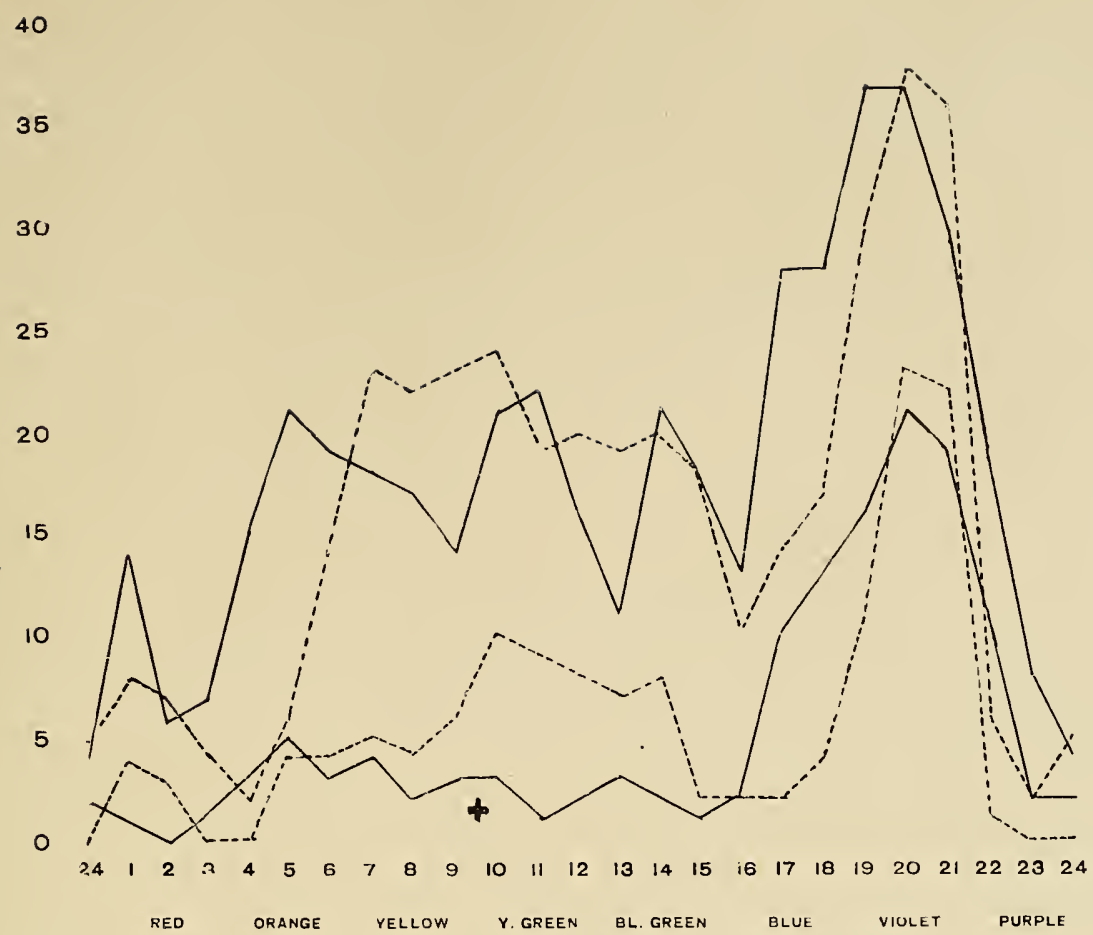

Fig. XVII.-Violet, Tints and Colours

$3 c$

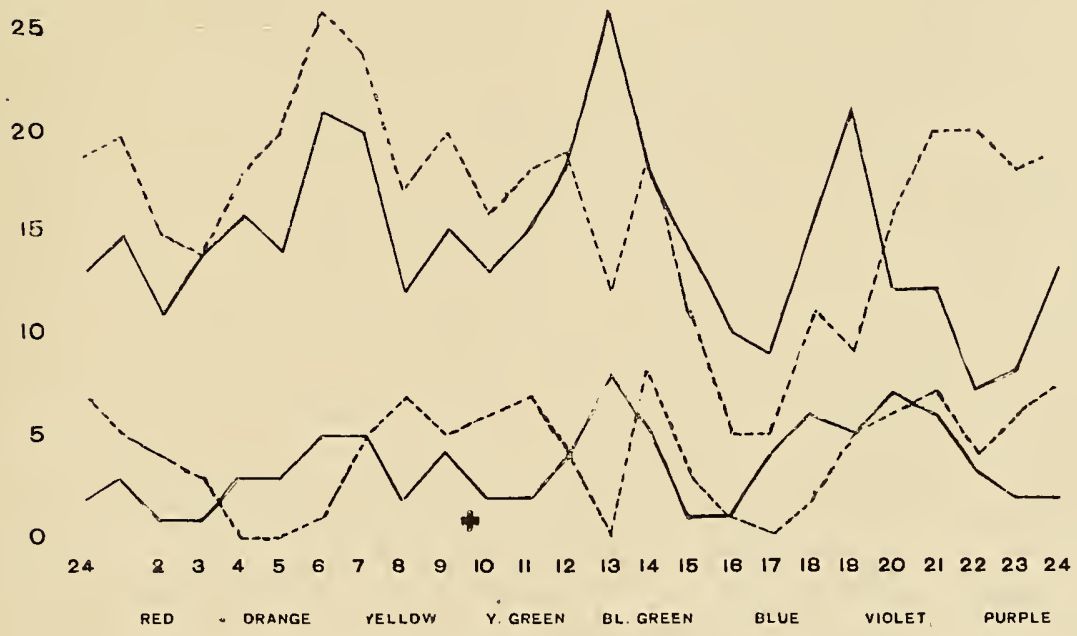

Fig. XViII.-Violett, Shades and Colours 



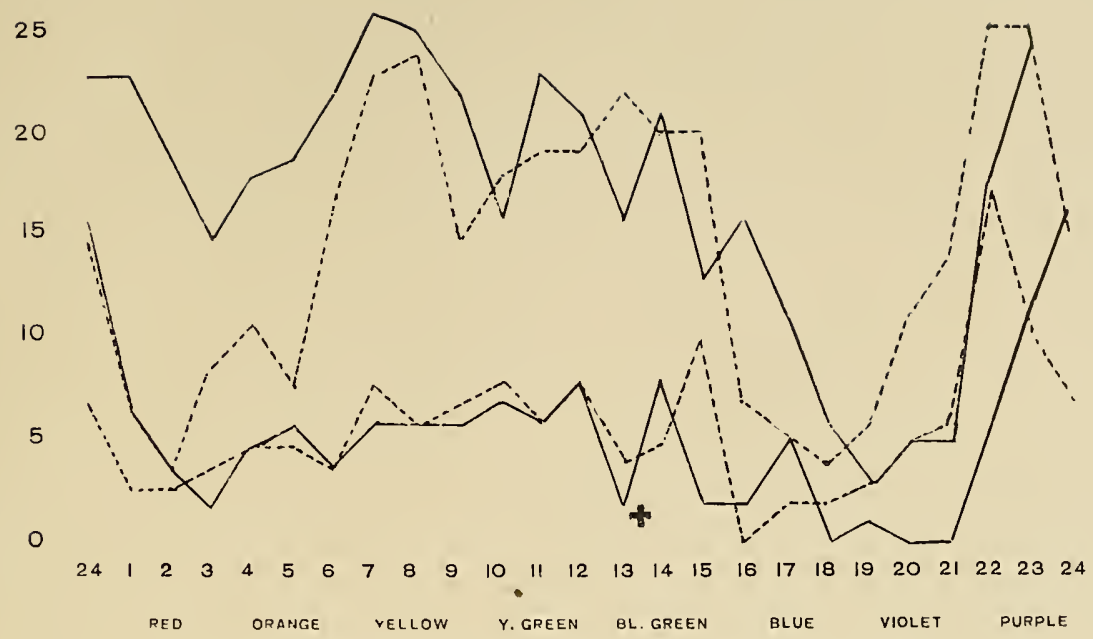

Fig. XIX.-Purple, Tints and Colours

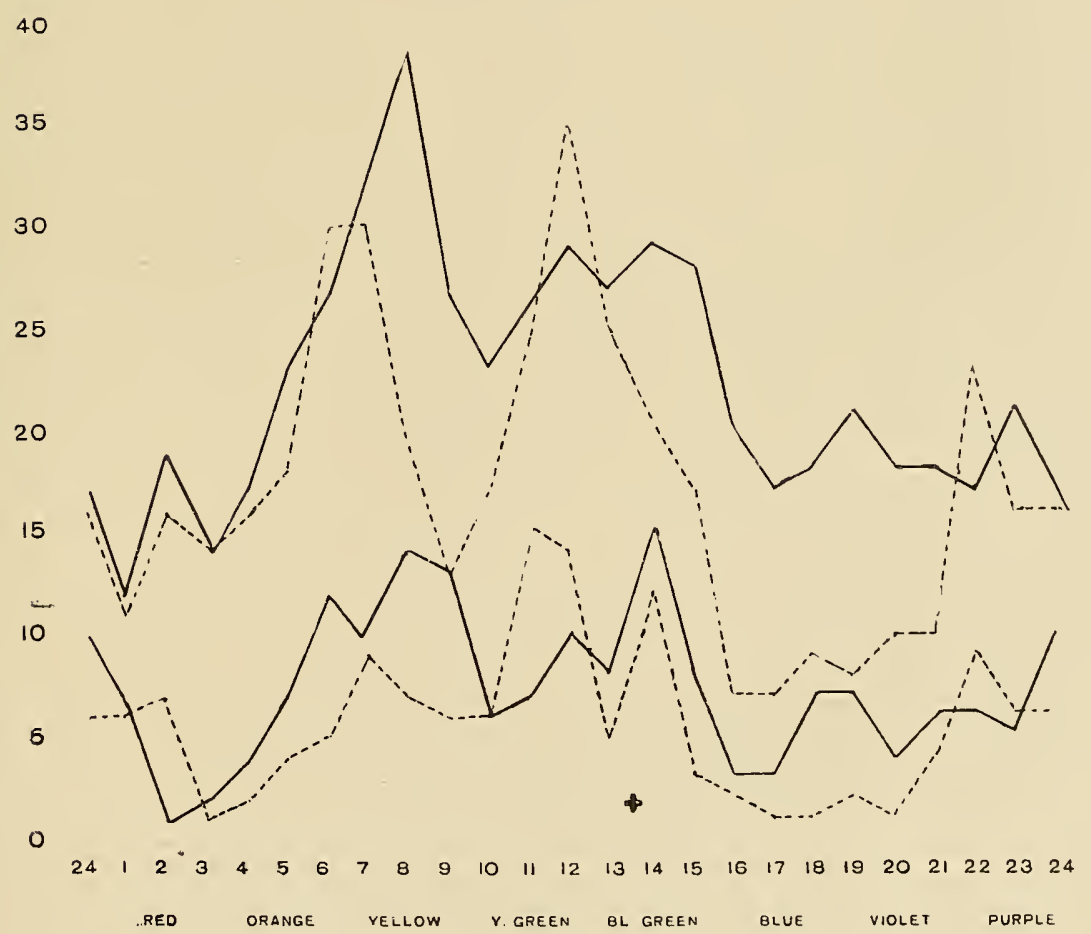

Fig. XX.-Purple, Shades and Colours 

150

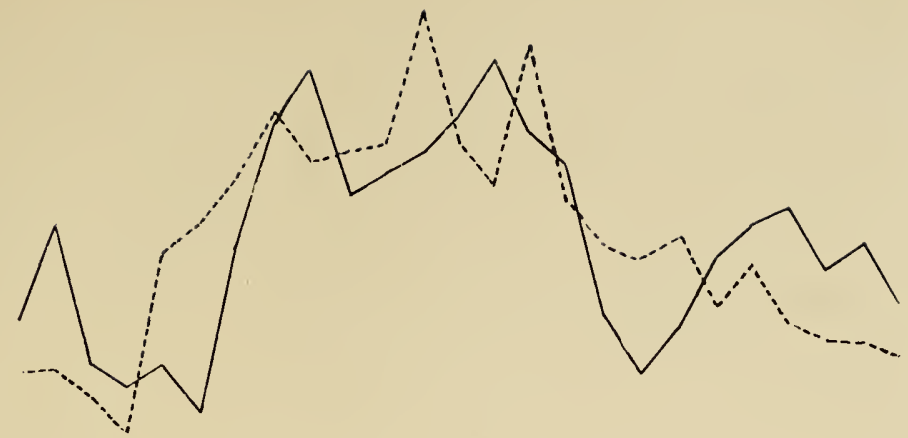

50

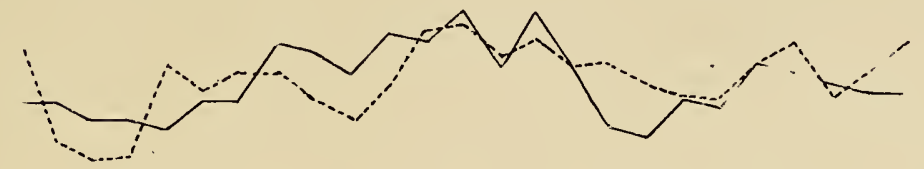

$\begin{array}{lllllllllllllllllllllllll}24 & 1 & 2 & 3 & 4 & 5 & 6 & 7 & 8 & 9 & 10 & 11 & 12 & 13 & 14 & 15 & 16 & 17 & 18 & 19 & 20 & 21 & 22 & 23 & 24\end{array}$

reo orange Yellow y.green BL. GREEN BLUE VIOLET PURPLE

Fig. XXI.-Summation Curve, Tints and Colours

250

200

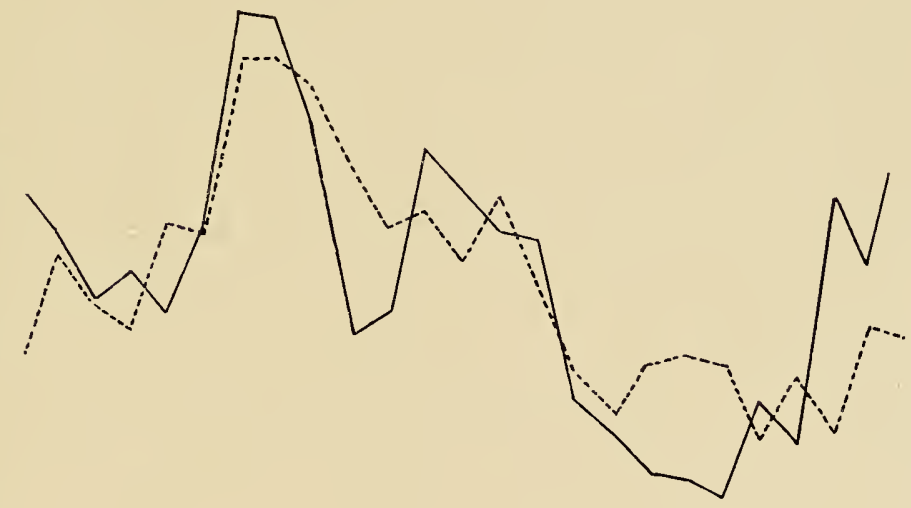

100

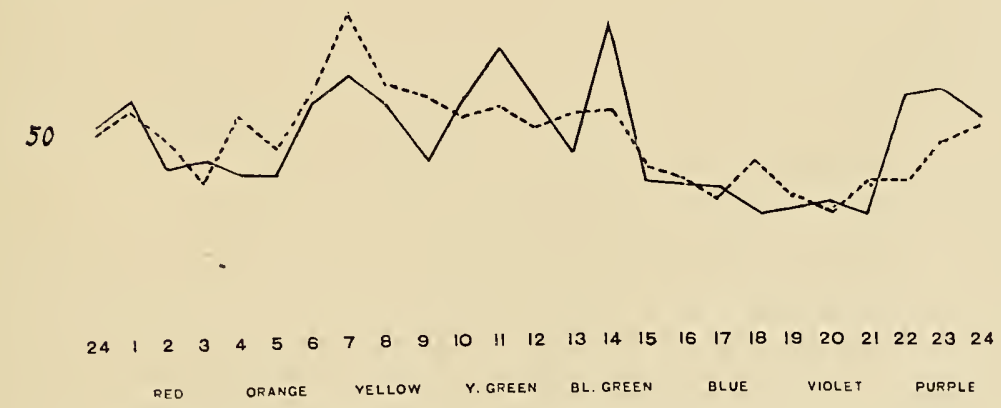

Fig. XXII.-Summation Curve, Shades and Colours 





\title{
STEREOSCOPIC VISION
}

AND ITS RELATION TO INTENSITY RND QUALITY OF LIGHT SENSATION

\author{
SECOND ARTICLE
}

STEREOSCOPIC VISION AND QUALITY OF LIGHT SENSATION

BY

T. R. ROBINSON, B.A. 

In the former $\operatorname{article~}^{1}$ an àccount was given of some experiments upon the application to the two retinas of light stimuli of different intensity. There are some phenomena of equal interest which occur when the respective parts of the stimulus are of different quality. The presentation of different colour stimuli simultaneously to the two eyes may have various results, according to the degree of difference in the quality of the stimuli. In the experiments now to be described the following questions were kept in view :

(I) Will the results obtained by the previously reported experiments with uncoloured light be essentially altered by the introduction of the colour factor?

(2) What are the limits of possibility for binocular mixture of qualitatively different retinal impressions?

1 University of Toronto Studies, Psychological Series, Vol. ii, No. 2.

(3) How is such binocular mixture of colours related to the stereoscopic combination of the retinal images, i.e., do differences of colour affect the stereoscopic combination, or, on the other hand, does the stereoscopic combination facilitate or hinder the binocular mixture of colours?

\section{COMPARISON OF MONOCULAR AND BINOCULAR INTENSITIES IN COLOURED LIGHT}

A few experiments were made upon this point in the course of an investigation by the author in connection with Fechner's paradox, ${ }^{1}$ referred to more fully in the preceding article. Those experiments, however, were comparatively few in number, and made with only one absolute intensity, so that the results were not conclusive. The chief differences from the results with white light were that the judgments were more difficult and less decided, and that the region of equality in intensity between monocular and binocular vision extended over a wider field. The differences between the results of the same two observers were noticeably greater than with

1 American Journal of Psychology, Vol. vii, No. I, pp. 9 etc. 
uncoloured light, perhaps because the intensity values of the colours were not the same for different observers.

A further series of experiments has been made, following a modification of the former method. The apparatus was the same as that used for the experiments in binocular lustre, ${ }^{1}$ except that the objects observed were plane coloured surfaces instead of stereoscopic objects. On each side were two brightly illuminated coloured surfaces, which were combined by means of the stereoscope. Before one of them the episkotister-disc was revolved, so that the surfaces differed in brightness, while remaining similar in all other respects. The difference in brightness could, of course, be varied by re-adjusting the disc. The colour was furnished by coloured gelatine or thin glass plates placed over the openings in the front screen of the apparatus, white paper being placed opposite them on the screen or wall at the back. The experiments were made in a dark room by two observers, who took turns in operating for each other. They began in each case with monocular vision, i.e., by looking through the stereoscope with the shutter covering the lens before which the disc revolved. Then, after the observer had looked for a few moments, the shutter was opened, and he at once reported whether the brightness was equal to, greater or less than that of monocular vision. A series was made by increasing the opening of the disc until the raising of the shutter plainly resulted in an increase of brightness, then by decreasing the opening until monucular and binocular intensities appeared equal, and still further until the opening of the shutter caused a just noticeable decrease of brightness. Then the opening of the disc was gradually widened till the equal region was reached again and still further till, on the opening of the shutter, there was a just noticeable increase of brightness. In the results of observer " $J$ " the average of the "equal" judgments is given for each series. The results of observer " $H$ " were calculated a little differently, taking the average of the degrees of opening of

1 University of Toronto Studies, Psychological Series. Vol. ii. No. 2, p. 77. 
the disc when the judgments were "brighter," "darker" and "equal," the values for "brighter" and "darker" being regarded as the limits for the region of equality. The colours used were from near the middle and ends of the spectrum, being respectively red, green and blue. Similar series were also made with white light for the purpose of comparison. The wave-lengths of the respactive colours were approximately as follows : red 615-740 $\mu \mu$, green $480-560 \mu \mu$, blue $440-500 \mu \mu$.

Certain special difficulties were found in experimenting with coloured light. First, there was the necessity of abstracting intensity changes from saturation changes with increasing or decreasing illumination. This made the judgments in some cases very difficult, especially with the blue light. When the opening of the disc was very small there was competition of the vision fields, that of the darkened eye having either no colour, or a slight tinge of yellow, due to binocular contrast. Secondly, the disturbing effect of afterimages had to be more carefully guarded against. Again, each observer found himself able to distinguish differences of brightness more readily with certain colours than with others. Thus the discrimination of " $\mathrm{H}$ " was best with green, that of "J" with red. A further obstacle in the way of comparing the results with different colours is that the same illumination could not be used for all the colours. With the red it was found necessary to use a 100 c.p. lamp, as with weaker illumination the "equal" limits could not be passed in both directions. On the other hand this very bright light had certain disturbing effects on account of which it was not used with the other colours; the fatigue of the eye was very great, and the after-images gave more trouble. Observer " $\mathrm{J}$ " noted, however, in spite of these hindrances, that discrimination was less difficult with red than with white light.

The results of these experiments are given in Tables I and II. They show the same general dependence of the relation of monocular to binocular intensity upon the absolute intensity of illumination as is shown in the experiments with uncoloured light. Difference of quality, therefore, does not apparently 
affect the intensity relations. Where the brightness of the coloured light is approximately the same as with red and green, the results show very little difference. On the other hand, the very great difference of average values between blue and red or green may perhaps not be due solely to the difference of brightness. This indeed seems probable in view of the fact that in the former experiments, where the colours were of equal brightness, the values for blue were with both observers higher than those for red.

TAble I.-Observer H.

\begin{tabular}{|c|c|c|c|c|c|}
\hline \multicolumn{3}{|c|}{ Light Used } & \multicolumn{3}{|c|}{$\begin{array}{l}\text { Amount of Light in the Second Eye } \\
\text { which has no effect on Brightness of } \\
\text { Common Visual Field }\end{array}$} \\
\hline Quality & Illumination & $\begin{array}{l}\text { Intensity } \\
\text { Photo- } \\
\text { metrically } \\
\text { Measured }\end{array}$ & $\begin{array}{l}\text { Opening of } \\
\text { the Disc }\end{array}$ & $\begin{array}{l}\text { Units of } \\
\text { Intensity }\end{array}$ & $\begin{array}{l}\text { Ratio of the } \\
\text { Light in the } \\
\text { Other Eye }\end{array}$ \\
\hline $\begin{array}{l}\text { Blue.... } \\
\text { Green... } \\
\text { Red.... } \\
\text { White.. }\end{array}$ & $\begin{array}{l}5 \circ \text { c.p. } 1 \mathrm{amp} \\
\text { 50 c.p. } 1 \mathrm{amp} \\
\text { roo c.p. } 1 \mathrm{amp} \\
\text { r } 6 \text { c.p. } 1 \mathrm{amp}\end{array}$ & $\begin{array}{l}\mathrm{r} \\
9.69 \\
10.00 \\
22.50\end{array}$ & $\begin{array}{r}90^{\circ} \\
253^{\circ} \\
235^{\circ} \\
267^{\circ}\end{array}$ & $\begin{array}{r}.25 \\
6.78 \\
6.50 \\
\times 6.65\end{array}$ & $\begin{array}{l}.25 \\
.70 \\
.65 \\
.74\end{array}$ \\
\hline
\end{tabular}

TABLE II.-ObSERVER J.

\begin{tabular}{|c|c|c|c|c|c|}
\hline \multicolumn{3}{|c|}{ Light Used } & \multicolumn{3}{|c|}{$\begin{array}{l}\text { Amount of Light in the Second Eye } \\
\text { which has no effect on Brightness of } \\
\text { Common Visual Field }\end{array}$} \\
\hline Quality & Illumination & $\begin{array}{l}\text { Intensity } \\
\text { Photo- } \\
\text { metrically } \\
\text { Measured }\end{array}$ & $\begin{array}{l}\text { Opening of } \\
\text { the Disc }\end{array}$ & $\begin{array}{c}\text { Units of } \\
\text { Intensity }\end{array}$ & $\begin{array}{l}\text { Ratio of the } \\
\text { Light in the } \\
\text { Other Eye }\end{array}$ \\
\hline $\begin{array}{l}\text { Blue..... } \\
\text { Green... } \\
\text { Red.... } \\
\text { White. . }\end{array}$ & $\begin{array}{l}\text { 50 c.p. lamp. } \\
\text { 50 c.p. lamp. } \\
\text { roo c.p. lamp. } \\
\text { r6 c.p. lamp. }\end{array}$ & $\begin{array}{r}r \\
9.69 \\
10.00 \\
22.50\end{array}$ & $\begin{array}{l}\operatorname{lr} 4^{\circ} \\
255^{\circ} \\
247 \\
267\end{array}$ & $\begin{array}{r}.3 r \\
6.86 \\
6.86 \\
\times 6.65\end{array}$ & $\begin{array}{l}.31 \\
.70 \\
.68 \\
.74\end{array}$ \\
\hline
\end{tabular}

II. BINOCULAR MIXTURE OF COLOURS

The experiments to be described in this section were conducted with the purpose of discovering the effects of various degrees of difference in quality between the two retinal impressions. There were four series of experiments : (I) the [190] 
first series was made with small coloured surfaces upon a dark field; (2) in the next series stereoscopic figures against a dark ground were observed, the impressions in the respective eyes being differently coloured; (3) in the third case, stereoscopic figures were employed, and one retinal image was coloured, the other uncoloured; (4) in the fourth series, an entirely different method was employed, and the colours occupied the whole vision field, instead of only a part of it.

(I) Plane coloured surfaces upon a dark field. The colours used were approximately spectrally pure, the surfaces observed being of Milton-Bradley coloured paper, illuminated by light which passed through combinations of coloured gelatines. A stereoscopic picture of the apparatus employed is shown in Fig. $I$, and a schematic representation of it, as seen from above, is given in Fig. 2. Across the back of a table, A, $66 \mathrm{~cm}$. long and $42 \mathrm{~cm}$. wide, is fixed a screen, B, of the same width as the table and $65 \mathrm{~cm}$. high; $18 \mathrm{~cm}$. before this screen is another, $\mathrm{C}$, of similar dimensions. Between these two screens, at the middle of the table there is a partition, D, to enable the right and left halves of the rear screen to be illuminated independently of each other. The top of the table and the surfaces of the screens and of the partition are a dead black. Upon the rear screen, two thin wooden discs, E, E, one on each side of the partition, are fastened by screws at the centre only, so that they may be turned at will. The surfaces of these discs are divided into seven sectors, covered with Milton-Bradley coloured papers. The discs are so placed that the inner edge of each comes close to the dividing partition. In the centre of the front screen, $25 \mathrm{~mm}$. apart, and one on each side of the partition, are two openings, a, a, $45 \mathrm{~mm}$. square, through each of which can be seen a portion of one sector only of the colour disc opposite it. Turning the discs thus brings each colour in succession before the openings. For illuminating the dises there are employed two sheet iron tubes, F, F, I $5 \mathrm{~cm}$. square, and 9I $\mathrm{cm}$. long. The front ends of these tubes are inserted through openings which they exactly fit in the front screen. The inner edges of the tubes 
are $16 \mathrm{~cm}$. apart, and they are on a level with the portions of the discs visible through the smaller openings before described. The latter are thus directly between the openings which admit the ends of the tubes. In order that the tubes may not interfere with the position of the observer before the apparatus, they are placed at an angle so that their outer ends are widely apart. In each tube is a moveable block, fitting the inside of the tube, to the front of which is attached a socket for an incandescent electric lamp. The upper side of each tube has a narrow slit, b, b, running nearly its whole length, through which projects an attachment to the block for affixing the wires which connect with the light socket, and a screw, c,c, for fixing the block at any desired distance from the ends of the tube. The front end of each tube is fitted with a groove, d,d, into which were slipped frames containing the combinations of gelatines through which the light passed before falling upon the sectors of the discs. During the experiments all other light was excluded from the room. By the use of varying combinations of papers and gelatines, the spectrum was divided into twelve approximately equal divisions. These colours are the same as were used by Miss Baker in her work upon the aesthetics of colour combinations. Their spectroscopical analysis is given below.

Spectroscopical Analysis of Colours.

\begin{tabular}{|c|c|c|c|c|}
\hline \multirow[b]{2}{*}{ Name of Colodr } & \multicolumn{2}{|c|}{ WITH NaRrow SiIT } & \multicolumn{2}{|c|}{ With Wide Sit } \\
\hline & $\begin{array}{l}\text { Visible part of } \\
\text { Spectrum in } \mu \mu\end{array}$ & $\begin{array}{l}\text { Region of great- } \\
\text { est intensity in } \\
\mu \mu\end{array}$ & $\begin{array}{l}\text { Visible part of } \\
\text { Spectrum in } \mu \mu\end{array}$ & $\begin{array}{c}\text { Region of great- } \\
\text { est intensity in } \\
\mu \mu\end{array}$ \\
\hline Red...... & $665(?)-592 \cdot 5$ & $635-6$ го & $67^{2} \cdot 5(?)-580$ & $657 \cdot 5^{-6}$ 工 5 \\
\hline Orange-Red & $622 \cdot 5-582 \cdot 5$ & 6 I2.5-592.5 & $635-580$ & $622 \cdot 5-59^{2} \cdot 5$ \\
\hline Orange........ & $607 \cdot 5-55^{2} \cdot 5$ & $585-562 \cdot 5$ & $622 \cdot 5-547 \cdot 5$ & $607 \cdot 5-562 \cdot 5$ \\
\hline Orange-Yellow. & $587 \cdot 5-547 \cdot 5$ & $562 \cdot 5-557 \cdot 5$ & $617 \cdot 5-537 \cdot 5$ & $602 \cdot 5-555$ \\
\hline Yellow........ & $580-5$ × $2 \cdot 5$ & $562 \cdot 5-535$ & 6 I $5-492 \cdot 5$ & $5^{87} \cdot 5^{-555}$ \\
\hline Yellow-Green... & $5^{6} 5-497 \cdot 5$ & $535-525$ & $580-480$ & $555-530$ \\
\hline Green......... & $54^{2} \cdot 5-49^{2} \cdot 5$ & $530-507 \cdot 5$ & $570-480$ & $537 \cdot 5^{-5} 77 \cdot 5$ \\
\hline Green-Blue. & $5^{2} 5^{-47^{2} \cdot 5}$ & $5 \div 2 \cdot 5-495$ & $55^{0}-447 \cdot 5$ & $5^{2} 5-502 \cdot 5$ \\
\hline Blue... . . & $570-460$ & $492 \cdot 5-475$ & $535-445$ & $57^{2} \cdot 5^{-49^{2} \cdot 5}$ \\
\hline Violet........ & $482 \cdot 5-432 \cdot 5$ & $470-462 \cdot 5$ & $497 \cdot 5-430$ & $475-455$ \\
\hline Violet-Purple \{ & $\begin{array}{l}687 \cdot 5-665 \\
485-440\end{array}$ & $462 \cdot 5-455$ & $\left\{\begin{array}{l}700-665 \\
487 \cdot 5-430\end{array}\right.$ & $470-45^{2} \cdot 5$ \\
\hline Purple. & $680-645$ & & $680-635$ & \\
\hline & $480-430$ & & $497 \cdot 5^{-430}$ & $475-460$ \\
\hline
\end{tabular}

[192] 
Their complementary relations are also stated very fully in Miss Baker's article. ${ }^{1}$ The purpose of the tubes containing the moveable lamps was to equalize the intensities of the two colours by adjusting the distances from them of the lamps. To facilitate this adjustment a certain intensity of the greenblue, a colour of medium intensity, was taken as the normal, and the positions of the lamps required for the various colours in order to give intensities equal to it were found and marked on the tubes. In a few cases, where one gelatine combination was very much more translucent than the other, the length of the tubes was found insufficient, and either a stronger light had to be used for the duller colour or a sheet of white tissue paper placed before the front of the other tube. The lamps commonly used throughout were 32 c.p. A moveable block was placed upon the front of the table in a groove which enabled it to slide backward and forward. To this block was attached an upright upon which was fixed, at the height of the openings in the screen, the hood of an ordinary stereoscope, G, in which the glasses had been replaced by others of a somewhat longer focal distance.

In the experiments the observer takes his seat in front of the apparatus. There are then before him in the darkened room two small square coloured surfaces, of different colours, but equally bright. Putting his head into the hood of the stereoscope, he adjusts the latter so that the two coloured surfaces completely coincide. All the facts regarding the colour of the surface seen are then noted, and the colour presented to one of the eyes remaining the same, that before the other is changed, and a new observation made. This is repeated till the constant colour has been combined with each of the other colours used. Then another colour is taken as the constant colour, and each of the others combined with it. To vary still further the conditions, with some observers each colour was presented to each of the eyes of the observer as the constant colour, so that it was twice combined with each

1 University of Toronto Studies, Psychological Series, Vol. ii, No.I, p. I6.

[193] 
of the other colours. Four combinations of each colour with each other colour were thus effected for each observer, each colour being presented to each eye once as the constant colour, and once as one of the changing series. With other observers the position of the constant colour was changed from right to left or vice versa after each series, but only one series was made for each colour. So that with these observers only two combinations of each colour with each other colour were obtained. Tables III to VIII give the combined results of six observers, with four of whom the former method was followed, with two the latter; so that in the experiments which these tables summarize each of the twelve colours has been combined with each of the others twenty times.

Table III.-Complete Rivalry.

i.e., BOTH COLOURS UNCHANGED.

\begin{tabular}{|c|c|c|c|c|c|c|c|c|c|c|c|c|c|}
\hline & $\mathrm{R}$ & OR & $\mathrm{O}$ & OY & $\mathrm{Y}$ & $Y G$ & G & GB & B & V & VP & $\mathrm{P}$ & \\
\hline R. & & 0 & 0 & 0 & ○ & 4 & 6 & IO & IO & 9 & 2 & I & 42 \\
\hline OR. & 0 & . & 0 & 0 & I & 2 & 4 & IO & 7 & 7 & 2 & 2 & 35 \\
\hline $\mathrm{O}_{i}$ & 0 & 0 & . & $\circ$ & ○ & I & 3 & 6 & 8 & 3 & 4 & 3 & 28 \\
\hline OY. & $\circ$ & 0 & 0 & $\circ$ & $\circ$ & 0 & 3 & 8 & 9 & 4 & 2 & 6 & $3^{2}$ \\
\hline Y. & $\circ$ & I & $\circ$ & 0 & . & 0 & 2 & 4 & 7 & 2 & I & 6 & 23 \\
\hline YG. & 4 & 2 & I & $\circ$ & $\circ$ & . & $\circ$ & I & 7 & I & 3 & 4 & 23 \\
\hline G.. & 6 & 4 & 3 & 3 & 2 & 0 & . & $\circ$ & I & 2 & 0 & 4 & 25 \\
\hline GB. & IO & IO & 6 & 8 & 4 & I & $\circ$ & . & 0 & 0 & $\circ$ & I & 40 \\
\hline B. & IO & 7 & 8 & 9 & 7 & 7 & I & $\circ$ & . & $\circ$ & 0 & 3 & $5^{2}$ \\
\hline $\begin{array}{l}\mathrm{V} \\
\mathrm{V}\end{array}$ & 9 & 7 & 3 & 4 & 2 & I & 2 & o & 0 & . & $\circ$ & 0 & 28 \\
\hline \multirow{3}{*}{$P \ldots \ldots \ldots$} & 2 & 2 & 4 & 2 & I & 3 & $\circ$ & 0 & 0 & $\circ$ & & 0 & I4 \\
\hline & I & 2 & 3 & 6 & 6 & 4 & 4 & I & 3 & ○ & ○ & . & 30 \\
\hline & $4^{2}$ & 35 & 28 & 32 & 23 & 23 & 25 & 40 & $5^{2}$ & $2 S$ & I 4 & 30 & 372 \\
\hline
\end{tabular}

Table IV.-Partial Rivalry,

i.e., RIVALRY OF THE VISION FIELDS, BUT WITH ONE OR BOTH COLOURS MODIFIED OR WEAKENED.

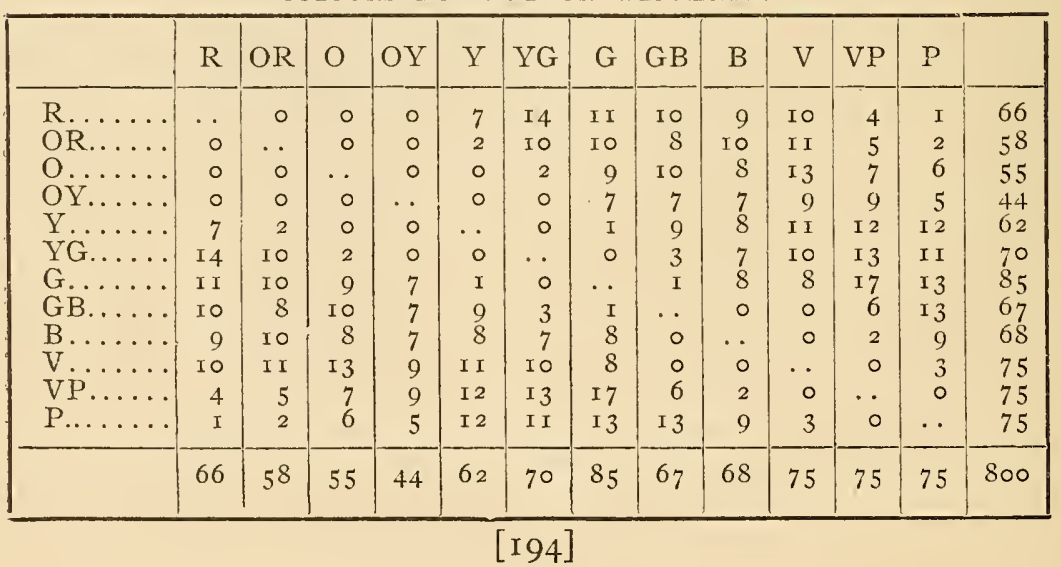




\section{ROBINSON : STEREOSCOPIC VISION}

Table V.-Inconstant Mrxture.

COMBINATIONS YIELDING A COLOUR WHICH IS A MIXTURE OF THE TwO MONOCULARLY SEEN, BUT INCONSTANT.

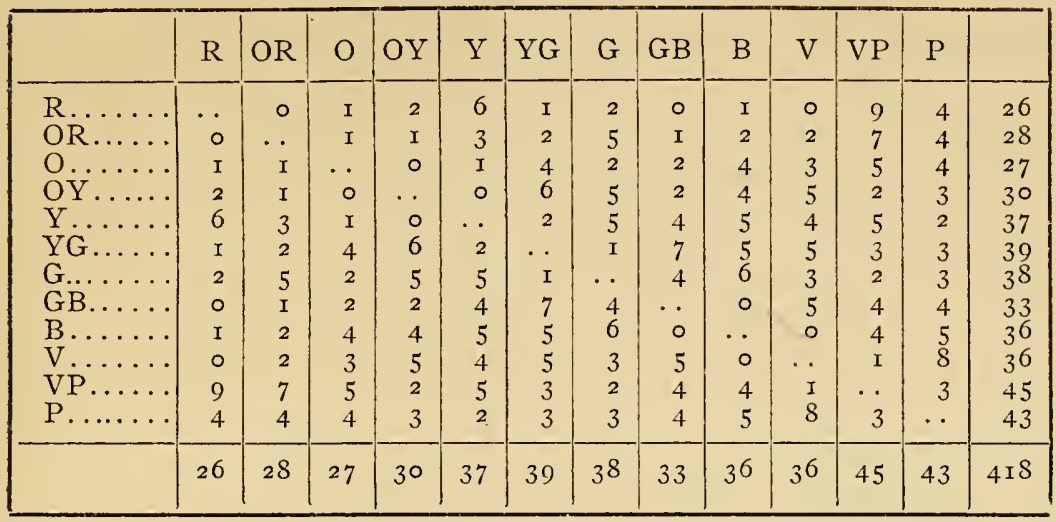

Table VI.-Complete Mixture.

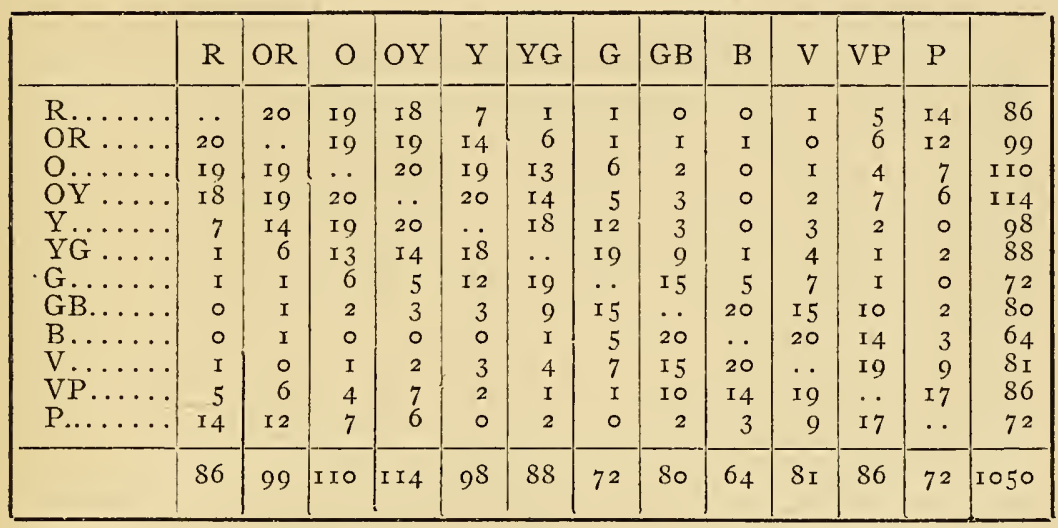

Table VII.-Summary of Number of Cases of the respective PHENOMENA FOR EACH COLOUR.

\begin{tabular}{|c|c|c|c|c|c|}
\hline & $\begin{array}{c}\text { Complete } \\
\text { Rivalry. }\end{array}$ & $\begin{array}{l}\text { Partial } \\
\text { Rivalry. }\end{array}$ & $\begin{array}{l}\text { Inconstant } \\
\text { Mixture. }\end{array}$ & $\begin{array}{l}\text { Complete } \\
\text { Mixture. }\end{array}$ & \\
\hline R.. & 42 & 66 & 26 & 86 & 220 \\
\hline OR.... & 35 & $5^{8}$ & 28 & 99 & 220 \\
\hline O..... & 28 & 55 & 27 & IIO & 220 \\
\hline OY.. & 32 & 44 & 30 & I I 4 & 220 \\
\hline$Y \ldots$ & 23 & 62 & 37 & 98 & 220 \\
\hline YG.. & 23 & 70 & 39 & 88 & 220 \\
\hline $\mathrm{G} \ldots \ldots$ & 25 & 85 & 38 & 72 & 220 \\
\hline GB... & 40 & 67 & 33 & 80 & 220 \\
\hline B..... & $5^{2}$ & 68 & 36 & 64 & 220 \\
\hline V... & $\cdot 28$ & 75 & 36 & $8 \mathrm{I}$ & 220 \\
\hline VP.... & $r_{4}$ & 75 & 45 & 86 & 220 \\
\hline \multirow[t]{2}{*}{ P.... } & 30 & 75 & 43 & 72 & 220 \\
\hline & 372 & 800 & 4I 8 & 1050 & 2640 \\
\hline
\end{tabular}


Table Vili.-Number of other Colours with which the VARIOUS PHENOMENA OCCUR FOR EACH COLOUR.

\begin{tabular}{|c|c|c|c|c|}
\hline & $\begin{array}{l}\text { Complete } \\
\text { Rivalry. }\end{array}$ & $\begin{array}{l}\text { Partial } \\
\text { Rivalry. }\end{array}$ & $\begin{array}{c}\text { Inconstant } \\
\text { Mixture. }\end{array}$ & $\begin{array}{l}\text { Complete } \\
\text { Mixture. }\end{array}$ \\
\hline 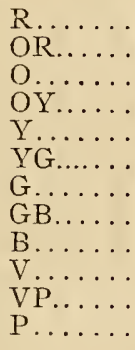 & $\begin{array}{l}7 \\
8 \\
7 \\
5 \\
7 \\
8 \\
8 \\
7 \\
8 \\
7 \\
6 \\
9\end{array}$ & $\begin{array}{r}8 \\
8 \\
7 \\
6 \\
8 \\
8 \\
10 \\
9 \\
9 \\
8 \\
9 \\
10\end{array}$ & $\begin{array}{r}8 \\
\text { IO } \\
\text { IO } \\
9 \\
\text { IO } \\
\text { I I } \\
\text { I I } \\
9 \\
9 \\
9 \\
\text { I I } \\
\text { I I }\end{array}$ & $\begin{array}{r}9 \\
10 \\
\text { 10 } \\
\text { I0 } \\
\text { I I } \\
10 \\
10 \\
7 \\
7 \\
10 \\
11 \\
9\end{array}$ \\
\hline & 87 & IOI & I I 8 & I I 4 \\
\hline
\end{tabular}

(2) Stereoscopic figures upon a dark field. In the experiments thus far recorded, the objects observed, though combined by means of the stereoscope, were simply plane surfaces differently coloured. The question naturally presented itself in connection with this method, whether the results would be different if three-dimensional figures were used instead of plane surfaces. There are, indeed, two questions of interest here, (I) whether the binocular mixture of colours is facilitated or impeded, the rivalry of the vision-fields intensified or lessened, by the effort of combining the outlines into a threedimensional figure, (2) the question of the effect which differences of colour have upon the stereoscopic combination of the figures. In investigating these points, it was, of course, desirable that the method foliowed should conform as nearly as possible to that of the former series of experiments. Accordingly the same apparatus and the same colours were used, but over the openings for observation in the front of the apparatus small squares of thin plate glass were placed, upon which the stereoscopic figures were etched. The glass surrounding the drawing was blackened to prevent the transmission or reflection of light. Three pairs of outline drawings were used, one forming a transparent octahedral crystal, another [196] 
on opaque hexagonal crystal, and the third a truncated pyramid, with the summit projecting toward the observer. The etchings were made in two ways, some being on clear glass with frosted lines, others on frosted glass with the lines clear. These figures are reproduced, as nearly as possible as they were used, in Figs. 3 to 5 . The experiments were conducted in the same manner as those with plane surfaces, the number of combinations of each colour with each other colour being in this case sixteen. The results as regards the mixture of colours are shown in Tables IX to XIV. Tables XV to XIX show the effect upon the stereoscopic combination of the differences in the colour of the objects.

Table IX.-Complete Rivalry-Stereoscopic Objects.

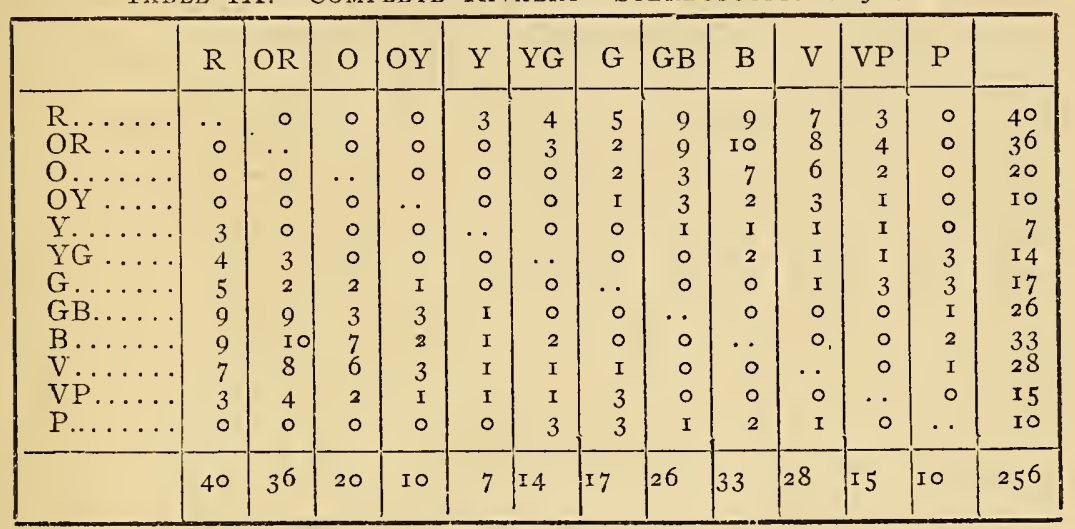

Table X.-Partial Rivalry-Stereoscopic Objects.

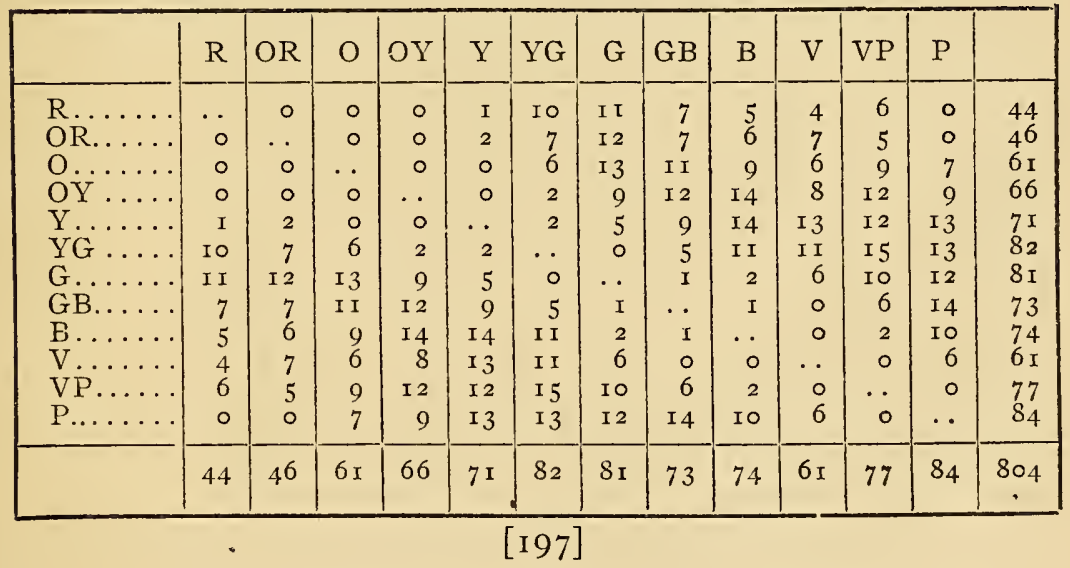


ROBINSON : STEREOSCOPIC VISION

Table XI.-Inconstant Mixture-Stereoscopic Objects

\begin{tabular}{|c|c|c|c|c|c|c|c|c|c|c|c|c|c|}
\hline & $\mathrm{R}$ & OR & $\mathrm{O}$ & OY & Y & YG & G & GB & B & $\mathrm{V}$ & VP & $\mathrm{P}$ & \\
\hline R...... & $\cdots$ & 0 & I & 3 & -5 & 2 & 0 & 0 & 2 & 4 & 5 & 0 & 22 \\
\hline OR .... & 0 & $\ldots$ & 0 & o & 2 & 5 & 2 & 0 & 0 & I & 6 & 2 & I 8 \\
\hline $\mathrm{O} \ldots \ldots$ & I & 0 & $\ldots$ & ० & 2 & 6 & I & 2 & 0 & 4 & 5 & 7 & 28 \\
\hline OY $\ldots$. & 3 & 0 & 0 & $\ldots$ & ० & 7 & 6 & 0 & 0 & 5 & 3 & 6 & 30 \\
\hline$Y \ldots \ldots$ & 5 & 2 & 2 & 0 & . . & I & 4 & 6 & I & 2 & 3 & 2 & 28 \\
\hline YG ... & 2 & 5 & 6 & 7 & I & $\ldots$ & 2 & 7 & 3 & 3 & 0 & 0 & 36 \\
\hline G. . & 0 & 2 & I & 6 & 4 & 2 & $\cdots$ & 2 & 7 & 7 & 3 & I & 35 \\
\hline GB..... & 0 & 0 & 2 & 0 & 6 & 7 & 2 & . & 3 & 9 & 8 & I & 38 \\
\hline B. & 2 & 0 & 0 & 0 & I & 3 & 7 & 3 & . & 2 & 8 & 4 & 30 \\
\hline & 4 & I & 4 & 5 & 2 & 3 & 7 & 9 & 2 & $\cdots$ & 4 & 7 & 48 \\
\hline VP...... & 5 & 6 & 5 & 3 & 3 & 0 & 3 & 8 & $\delta$ & 4 & . . & 5 & 50 \\
\hline \multirow[t]{2}{*}{ P....... } & 0 & 2 & 7 & 6 & 2 & $\circ$ & I & I & 4 & 7 & 5 & . & 35 \\
\hline & 22 & I 8 & 28 & 30 & 28 & 36 & 35 & $3^{8}$ & 30 & 48 & 50 & 35 & 398 \\
\hline
\end{tabular}

Table XII.-Complete Mixture-Stereoscopic Objects.

\begin{tabular}{|c|c|c|c|c|c|c|c|c|c|c|c|c|c|}
\hline & $\mathrm{R}$ & OR & $\mathrm{O}$ & OY & $\mathrm{Y}$ & $Y G$ & $\mathrm{G}$ & GB & B & V & VP & $\mathrm{P}$ & \\
\hline R. . & $\ldots$ & I 6 & I 5 & I 3 & $?$ & 0 & 0 & 0 & 0 & I & 2 & I6 & 70 \\
\hline OR .... & I 6 & . & I 6 & 16 & I 2 & I & $\circ$ & 0 & 0 & 0 & I & I 4 & 76 \\
\hline O...... & I 5 & I 6 & . & I 6 & I 4 & 4 & 0 & 0 & 0 & 0 & 0 & 2 & 67 \\
\hline OY..... & I 3 & I 6 & I 6 & . & I 6 & I 3 & 7 & 0 & o & 0 & 0 & I & 70 \\
\hline Y.. & 7 & I 2 & I 4 & I 6 & $\ldots$ & 7 & 0 & I & 0 & 0 & 0 & I & 70 \\
\hline YG & 0 & I & 4 & 7 & I 3 & $\therefore$ & I 4 & 4 & 0 & I & 0 & 0 & 44 \\
\hline G. . & 0 & o & 0 & 0 & 7 & I 4 & $\ldots$ & $\mathrm{I}_{3}$ & 7 & 2 & o & 0 & 43 \\
\hline GB.. & 0 & o & o & I & $\circ$ & 4 & I3 & $\ldots$ & I 2 & 7 & 2 & o & 39 \\
\hline B. & $\circ$ & o & $\circ$ & 0 & $\circ$ & 0 & 7 & I 2 & . & I 4 & 6 & $\circ$ & 39 \\
\hline & I & $\circ$ & $\circ$ & $\circ$ & $\circ$ & I & 2 & 7 & I 4 & $\ldots$ & I 2 & 2 & 39 \\
\hline VP..... & 2 & I & o & 0 & o & 0 & ० & 2 & 6 & I 2 & . & I I & 34 \\
\hline \multirow[t]{2}{*}{ P...... } & I 6 & I 4 & 2 & I & I & 0 & $\circ$ & ० & 0 & 2 & I I & . & 47 \\
\hline & 70 & $7^{6}$ & 67 & 70 & 70 & 44 & 43 & 39 & 39 & 39 & 34 & 47 & 638 \\
\hline
\end{tabular}

Table Xill.-Summary-No. of Cases-Stereoscopic Objects.

\begin{tabular}{|c|c|c|c|c|c|}
\hline & $\begin{array}{l}\text { Complete } \\
\text { Rivalry. }\end{array}$ & $\begin{array}{l}\text { Partial } \\
\text { Rivalry. }\end{array}$ & $\begin{array}{c}\text { Inconstant } \\
\text { Mixture. }\end{array}$ & $\begin{array}{l}\text { Complete } \\
\text { Mixture. }\end{array}$ & \\
\hline 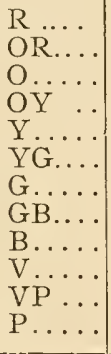 & $\begin{array}{r}40 \\
36 \\
20 \\
10 \\
7 \\
14 \\
17 \\
26 \\
33 \\
28 \\
15 \\
10\end{array}$ & $\begin{array}{l}44 \\
46 \\
61 \\
66 \\
71 \\
82 \\
81 \\
73 \\
74 \\
61 \\
77 \\
84\end{array}$ & $\begin{array}{l}22 \\
\text { IS } \\
28 \\
30 \\
2 S \\
36 \\
35 \\
38 \\
30 \\
48 \\
50 \\
35\end{array}$ & $\begin{array}{l}70 \\
76 \\
67 \\
70 \\
70 \\
44 \\
43 \\
39 \\
39 \\
39 \\
34 \\
47\end{array}$ & $\begin{array}{l}\text { I } 76 \\
\text { I } 76 \\
\text { I } 76 \\
\text { I } 76 \\
\text { I } 76 \\
\text { I } 76 \\
\text { I } 76 \\
\text { I } 76 \\
\text { I } 76 \\
\text { I } 76 \\
\text { I } 76 \\
\text { I } 76\end{array}$ \\
\hline & 276 & 800 & 398 & 638 & $2 \operatorname{II} 2$ \\
\hline
\end{tabular}

[198] 
Table XIV.-Summary-No. of Colours-Stereoscopic Objects.

\begin{tabular}{|c|c|c|c|c|}
\hline & $\begin{array}{l}\text { Complete } \\
\text { Rivalry }\end{array}$ & $\begin{array}{l}\text { Partial } \\
\text { Rivalry. }\end{array}$ & $\begin{array}{l}\text { Inconstant } \\
\text { Mixture. }\end{array}$ & $\begin{array}{l}\text { Complete } \\
\text { Mixture. }\end{array}$ \\
\hline 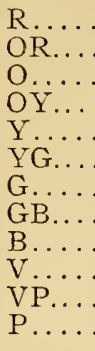 & $\begin{array}{l}7 \\
6 \\
5 \\
5 \\
5 \\
6 \\
7 \\
6 \\
7 \\
8 \\
7 \\
5\end{array}$ & $\begin{array}{r}7 \\
7 \\
7 \\
7 \\
9 \\
10 \\
10 \\
10 \\
10 \\
8 \\
9 \\
8\end{array}$ & $\begin{array}{r}7 \\
6 \\
8 \\
6 \\
\text { I0 } \\
9 \\
\text { I0 } \\
\text { S } \\
8 \\
\text { I I } \\
\text { I0 } \\
9\end{array}$ & $\begin{array}{l}7 \\
7 \\
6 \\
7 \\
7 \\
7 \\
5 \\
6 \\
4 \\
7 \\
6 \\
7\end{array}$ \\
\hline & 74 & 102 & 102 & 76 \\
\hline
\end{tabular}

Table XV.--Object, Transparent Crystal on Clear Glass.

\begin{tabular}{|c|c|c|c|c|}
\hline \multirow{2}{*}{$\begin{array}{c}\text { Result of Colour } \\
\text { Combination. }\end{array}$} & \multicolumn{4}{|c|}{ STEREOSCOPIC EFFECT. } \\
\cline { 2 - 5 } & Perfect. & Impaired. & Slight. & None. \\
\hline Complete Rivalry.... & 0 & 5 & 9 & 7 \\
\hline Partial Rivalry ...... & 24 & 46 & I4 & 5 \\
\hline Inconstant Mixture... & 25 & 2 I & 5 & 0 \\
\hline Complete Mixture.... & I02 & I & 0 & 0 \\
\hline & I5 & 73 & 28 & I 2 \\
\hline
\end{tabular}

Table XVI.-Object, Opaque Crystal on Ground Glass.

\begin{tabular}{|c|c|c|c|c|}
\hline \multirow{2}{*}{$\begin{array}{l}\text { Result of Colour } \\
\text { Combination. }\end{array}$} & \multicolumn{4}{|c|}{ Stereoscopic Effect. } \\
\hline & Perfect. & Impaired. & Slight. & None. \\
\hline Complete Rivalry... . & I & I & I & I 4 \\
\hline Partial Rivalry...... & 21 & 26 & 6 & $5^{2}$ \\
\hline Inconstant Mixture... & 35 & 2 I & 4 & 3 \\
\hline \multirow{2}{*}{ Complete Mixture.... } & 79 & $\circ$ & $\circ$ & $\circ$ \\
\hline & I 36 & 48 & II & 69 \\
\hline
\end{tabular}


Table XVil.-Object, Pyramid on Clear Glass.

\begin{tabular}{|c|c|c|c|c|}
\hline $\begin{array}{c}\text { Result of Colour } \\
\text { Combination. }\end{array}$ & \multicolumn{4}{|c|}{ Stereoscopic EfFECt. } \\
\cline { 2 - 5 } & Perfect. & Impaired. & Slight. & None. \\
\hline Complete Rivalry.... & 27 & 2 & 2 & I \\
\hline Partial Rivalry...... & 70 & 34 & 6 & I \\
\hline Inconstant Mixture... & 39 & 2 & 0 & 0 \\
\hline Complete Mixture... & 80 & 0 & $\circ$ & 0 \\
\hline & 2 I6 & 38 & 8 & 2 \\
\hline
\end{tabular}

Table XVIII.-Object, Pyramid on Ground Glass.

\begin{tabular}{|c|c|c|c|c|}
\hline $\begin{array}{c}\text { Result of Colour } \\
\text { Combination. }\end{array}$ & \multicolumn{3}{|c|}{ STEReoscopic Effect. } \\
\cline { 2 - 3 } & Perfect. & Impaired. & Slight. & None. \\
\hline Complete Rivalry.... & 2 & I5 & I 8 & I7 \\
\hline Partial Rivalry...... & II & 50 & I 8 & I9 \\
\hline Inconstant Mixture... & 20 & r7 & 3 & 0 \\
\hline Complete Mixture... & 74 & 0 & 0 & 0 \\
\hline & ro7 & 82 & 39 & 36 \\
\hline
\end{tabular}

Table XIX.-Summary of XV.-XVIII.

\begin{tabular}{|c|c|c|c|c|}
\hline \multirow{2}{*}{$\begin{array}{l}\text { Result of Colour } \\
\text { Combination. }\end{array}$} & \multicolumn{4}{|c|}{ Stereoscopic Effect. } \\
\hline & Perfect. & Impaired. & Slight. & None. \\
\hline Complete Rivalry.... & 30 & 23 & 30 & 39 \\
\hline Partial Rivalry... & I 26 & I 56 & 44 & 77 \\
\hline Inconstant Mixture... & x 19 & $6 \mathrm{I}$ & I 2 & 3 \\
\hline \multirow[t]{2}{*}{ Complete Mixture.... } & 335 & I & $\circ$ & $\circ$ \\
\hline & 610 & $24 \mathrm{r}$ & 86 & I I9 \\
\hline
\end{tabular}


Remarks on the tables in sections ( 1 ) and (2). The tables group the results in four divisions, according to the activity of the colours, i.e., the liveliness and persistency of the rivalry of the vision-fields, the two extremes being "complete rivalry," where the impressions in the respective eyes have qualitatively no influence upon each other, and "complete mixture," where there is an entire fusion of the two impressions.

The cases of complete rivalry for plane surfaces and stereoscopic figures respectively are shown in Tables III and IX. These are the only cases where there is absolutely no mixture effect, and their numbers are comparatively quite small. They are much less numerous than the cases of complete mixture, and are not a large proportion of the total. This phenomenon, as might be expected, was most frequent where the colours were nearly complementary (there was not any pair of exact complementaries), where also the cases of complete mixture were least frequent. The proportion of cases of complete rivalry was on the whole, slightly greater with stereoscopic objects than with surfaces.

The cases classified as "partial rivalry," and exhibited in Tables IV and $\mathrm{X}$ are very interesting. They show that even when there is most pronounced strife of the vision-fields, there is frequently at the same time a certain mixture effect. Either one or each of the competing colours is modified in the direction of the other, (e.g., red and green being the colours, the red appearing more orange-red and the green nearer to yallow) or else, especially where the colours are nearly complementary, one or both will appear paler than when seen alone, i.e., of less saturation. Comparison of these two tables shows a marked difference between the results with threedimensional objects and those with plane surfaces. The proportion of cases of partial rivalry is decidedly larger with the former than with the latter.

Tables V and XI, "inconstant mixture," represent a variety of cases, ranging from those where there was a single colour, which, when regarded for a time, changed slightly toward one or the other of the competing colours and back again, 
or toward each in turn, to those in which there was a decided strife of the vision-fields, but with a mixed colour appearing between the alternation of the competing colours. These phenomena, as will be seen from the numbers in these tables, are comparatively infrequent. There is a decided difference between the proportion of cases of partial mixture with threedimensional objects and that with plane surfaces, the proportion being greater with the former.

Tables VI and XII show the cases of complete mixture of the colours. These cases are more numerous than might have been expected, in fact they form a very much larger proportion of the total number of combinations than do any of the others. Complete mixture of colours is not nearly as common with stereoscopic objects as with plane surfaces, showing that the effort required for the stereoscopic combination interferes decidedly with the complete mixing of the colours, though it has been shown, on the other hand, to produce a partial mixture effect more frequently than that occurs with plane surfaces.

Four tables of summaries are added, giving the totals of the preceding tables in parallel columns for convenience of comparison. Tables VII and XIII give the total numbers of cases of the occurrence of the respective phenomena. They show that the phenomenon which occurred most frequently with surfaces was that of complete mixture, with stereoscopic objects that of partial rivalry. With surfaces rivalry of modified colours was the next in order of frequency, and rivalry of unmodified colours in both cases much the least frequent of all. The proportion of cases of complete mixture is larger in Table VII than in Table XIII, but the cases of complete rivalry are also more numerous here. These results have been noticed already in connection with the preceding tables. These combined tables, however, furnish in addition a basis for comparison of the various colours with respect to the facility or difficulty with which they mix with other colours. Tables VIII and XIV summarize the results from a slightly different view. They show, not the number of times each phenomenon [202] 
occurs with each of the colours, but the number of other colours the combination of which with each of the colours results in the production of the respective phenomena. These four tables of summaries are illustrated graphically in Curves $I$ to IV, in which the abscissa lines represent the twelve spectral intervals and the ordinates represent respectively the number of cases and the number of colours. The results as to numbers of colours and numbers of cases of occurrence correspond quite well. The spectral colours near the purple end are, on the whole, shown to be somewhat more active, i.e., to mix less readily, than those at the opposite end. The regions of greatest and of least mixture, however, are found between the middle and the ends. The colour which mixes most frequently and with the greatest number of other colours is the same in all the curves, namely, orange-yellow. From that point the curve goes somewhat regularly and sharply upward to blue, whence it abruptly declines.

Tables XV to XIX show the effect upon the stereoscopic combination of the differences in the colour of the impressions in the respective eyes. The results for each of the pairs of drawings used are given in a separate table, and the combined results in Table XIX. From these tables it appears that the combination is seldom much impaired where the colours are not too different to admit of even partial mixture. With rivalry of modified colours the stereoscopic effect was often completely preservad, and even in a number of cases with rivalry of pure colours. The cases in which there was no stereoscopic effect were comparatively few. (They occurred for the most part only where the competing colours succeeded each other very rapidly). They occurred also mainly, as the tables show, with the etchings upon ground glass, where also the complete mixture of colours was less common. This is no doubt to be explained by the fact that in these cases the colour contrast was stronger upon the lines than upon the surfaces.

A fact worthy of note is that with all the observers there appeared occasionally a lustre similar to that produced by [203] 
the combining of black and white objects or surfaces. With this there appeared also usually a "transparence" effect, one colour being reported as "seen through" the other. Careful examination of these cases showed them to be due to slight differences of brightness between the two colours. Re-adjustment of the lights always caused the lustre or transparence to disappear. These cases, however, suggest an interesting question regarding the problem of binocular lustre, as they seem to indicate that that phenomenon may be produced with much smaller differences of intensity between the two retinal impressions, where there is also a marked difference of quality.

(3) Mixture of coloured and uncoloured impressions. The apparatus and method employed in this series of experiments were the same as in the two preceding, and the objects were the same as in the last series, except that while one of the colours before described was behind the drawing presented to one eye, behind that presented to the other was one of a series of greys. Only one pair of the drawings described in section (2) were used, namely, those etched upon clear glass, and forming a transparent octahedral crystal (Fig. 3). Six greys of the Prang series were used, selected so as to be about equally graduated in brightness. In experimenting, the colour in use was made of equal intensity with the grey by adjusting the position of the lamps, in the same manner as before described for equalizing the intensity of the two colours in the experiments where different colours were presented to the respective eyes. The light illuminating the grey was passed through a gelatine which excluded any trace of yellow, leaving the light as nearly as possible absolutely colourless. Each of the six greys was combined with each of the twelve colours, the greys being kept on one side. Then the grey and the colour were interchanged, bringing the grey before the other eye, and the series repeated. Such a double series was made by one observer only, and by another a single series. There were thus in all three combinations of each of the six greys with each of the twelve colours. The total number of experi- 
ments was therefore not nearly so great as in the investigation regarding the mixture of coloured and uncoloured impressions. The results, however, are of decided interest. They are in some respects more regular than with combinations of two colours, and exhibit other marked differences from the former results. The results of one series are given in full in Tables $\mathrm{XX}$ to XXV. The results of all three series are summarized in Tables XXVI to XXVIII. They are also graphically represented in Curves V to VII. Curve V combines the results in Tables XXVI and XXVII-the results for one observer. Curve VI represents the results for the other observer, and Curve VII gives the combined results of the two observers.

Table XX.-Observer P. T. Grey No. I in Left Eye.

\begin{tabular}{|c|c|}
\hline Colour in Right Eye. & Effect of Combination. \\
\hline Red.. & $\begin{array}{l}\text { Rivalry at first of light grey and brilliant red, } \\
\text { then of grey and dull orange, finally mixing }\end{array}$ \\
\hline Orange-Red. . & $\begin{array}{l}\text { Slight rivalry, subsiding almost immediately } \\
\text { into light brown mixture. }\end{array}$ \\
\hline Orange...... & Less rivalry. Unsteady brown mixture. \\
\hline Orange-Yellow. & Same effect as with orange, only lighter brown. \\
\hline Yellow. & $\begin{array}{l}\text { Mixture, saturation growing less till yellow } \\
\text { becomes very faint. }\end{array}$ \\
\hline Yellow-Green. & Rivalry at first, then yellowish mixture. \\
\hline Green...... & $\begin{array}{l}\text { Mixture, green gradually fading. Final effect } \\
\text { good pea-green. }\end{array}$ \\
\hline Green-Blu & No rivalry. Grey-green, fading to greenish grey. \\
\hline Blue. & $\begin{array}{l}\text { At first rivalry of blue and grey, then mixture, } \\
\text { with blue predominating at centre and grey } \\
\text { at periphery. }\end{array}$ \\
\hline Violet. & Rivalry of bluish grey and pale violet in outer \\
\hline Violet-P & Strong rivalry of greyish yellow and purple. \\
\hline Purple.. & $\begin{array}{l}\text { At first rivalry between light grey and purple } \\
\text { of less saturation than when seen alone, finally } \\
\text { settling into a faint yellow, with at times a } \\
\text { suggestion of pink. }\end{array}$ \\
\hline
\end{tabular}


Table XXI.-Observer, P.T. Grey No. 2 in Left Eye.

\begin{tabular}{|c|c|}
\hline Colour in Right Eye. & EFFECT of Combination. \\
\hline Red & $\begin{array}{l}\text { Strong rivalry at first between red and grey, then } \\
\text { less pronounced rivalry between red and } \\
\text { orange-red. }\end{array}$ \\
\hline Orange-Red. & $\begin{array}{l}\text { Slight rivalry of grey and orange, then mixture, } \\
\text { orange with decided red spots. Finally settles } \\
\text { into a brown. }\end{array}$ \\
\hline Orange........ & Light brown. No rivalry. \\
\hline Orange-Yellow.. & $\begin{array}{l}\text { No rivalry. A light grey, with beautiful orange } \\
\text { tinge in parts. }\end{array}$ \\
\hline Yellow. & Pale, slightly inconstant yellow. \\
\hline Yellow-Green & Complete mixture, very slightly greenish grey. \\
\hline Green....... & Complete mixture, light pea-green. \\
\hline Green-Blue.. & $\begin{array}{l}\text { Rivalry of grey and blue, settling down to a } \\
\text { light grey with a tinge of blue. }\end{array}$ \\
\hline Blue. & Dark grey, with slight suggestion of blue at \\
\hline Violet. . & Rivalry of violet and yellowish grey. Always \\
\hline Violet-Purple & Rivalry of yellowish grey and purple. After a \\
\hline Purple. & $\begin{array}{l}\text { time grey lasts the longer. } \\
\text { Rivalry at first of light brown and purple, settling } \\
\text { into an unsteady purplish brown. }\end{array}$ \\
\hline
\end{tabular}

Table XXII.-Observer, P. T. Grey No. 3 in Left Eye.

\begin{tabular}{|c|c|}
\hline Colour in Right Eye. & EFfect of Combination. \\
\hline Red & No rivalry. A light grey with slight pinkish \\
\hline Orange-Red & $\begin{array}{l}\text { No rivalry. Surface bright, with faint tinge of } \\
\text { pink. }\end{array}$ \\
\hline Orange $\ldots . .$. & A faint pink, increasing in saturation. No rivalry ; \\
\hline $\begin{array}{l}\text { Orange-Yellow } \\
\text { Yellow ....... }\end{array}$ & $\begin{array}{l}\text { A pinkish white. No rivalry. } \\
\text { No rivalry. Mixture appears like a dirty white. }\end{array}$ \\
\hline Yellow-Green & Complete mixture, light green. \\
\hline 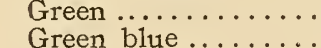 & $\begin{array}{l}\text { A very light grey, with a suggestion of green. } \\
\text { No rivalrv. An agreeable light blue. }\end{array}$ \\
\hline Blue. ..... & Light grey, with suggestion of blue. \\
\hline Violet. & $\begin{array}{l}\text { Rivalry of violet and yellowish grey, the grey } \\
\text { predominating. }\end{array}$ \\
\hline Violet-Purple & $\begin{array}{l}\text { Slight rivalry at first. Soon becomes a light } \\
\text { grey, with suggestion of yellow. A portion } \\
\text { of surface is covered with faint purple. Around } \\
\text { periphery is dark blue. }\end{array}$ \\
\hline Purple . & $\begin{array}{l}\text { Over a light brownish surface a slight and } \\
\text { indefinite purple moves. Around periphery } \\
\text { there is a bluish tinge. }\end{array}$ \\
\hline
\end{tabular}


Table XXili.-Observer P. T. Grey No. 4 in Left Eye.

\begin{tabular}{|c|c|}
\hline Colour in Right Eye. & EFfect of Combination. \\
\hline Red.. & Rivalry of white with red which gradually \\
\hline Orange-Red. & Faint orange. No rivalry. \\
\hline Orange....... & Rivalry of white and pale red. \\
\hline Orange-Yellow. & Complete mixture, pinkish white. \\
\hline Yellow....... & Mixture, very light b-wn. \\
\hline Yellow-Green. & Perfect mixture, light green. \\
\hline Green....... & Perfect mixture, pale pea-green. \\
\hline Green-Blue. & Complete mixture, very light blue \\
\hline Blue...... & Rivalry of white and very pale blue. \\
\hline $\begin{array}{l}\text { Violet......... } \\
\text { Violet-Purple. }\end{array}$ & $\begin{array}{l}\text { Continuous rivalry. } \\
\text { Rivalry. Grey appears white. Colour never }\end{array}$ \\
\hline & $\begin{array}{l}\text { covers whole surface, but is stronger around } \\
\text { edges. }\end{array}$ \\
\hline Purple.. & Continuous rivalry. The grey appears white. \\
\hline
\end{tabular}

Table XXIV.—Observer, P.T. Grey No. 5 in Left Eye.

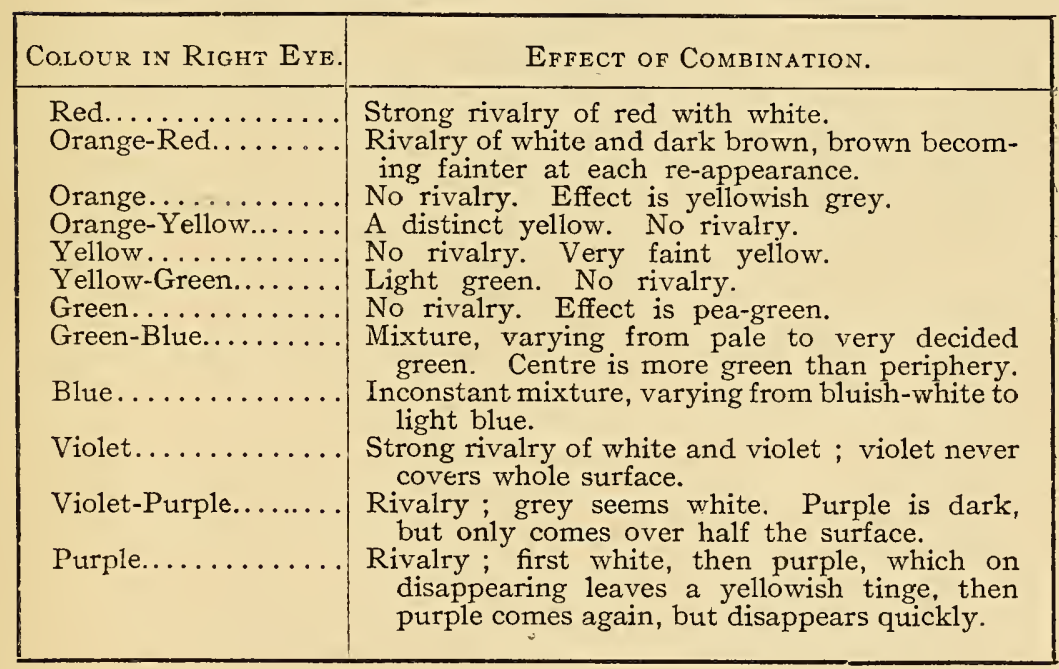


Table XXV.-Observer, P.T. Grey No. 6 in Left Eye.

\begin{tabular}{|c|c|}
\hline Colour in Right Eye. & EFFECT OF COMBINATION. \\
\hline 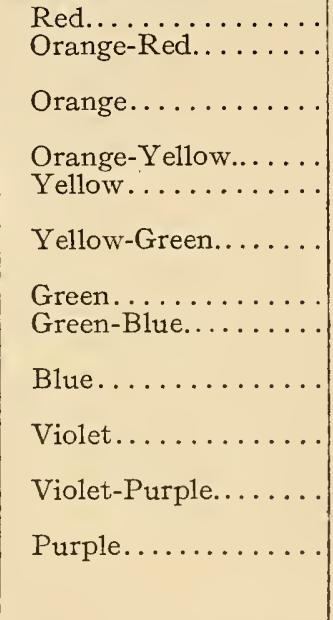 & $\begin{array}{l}\text { Rivalry of red and white. } \\
\text { Rivalry of white and brownish red, the white } \\
\text { predominating. } \\
\text { Rivalry, changes not very rapid. The appear- } \\
\text { ance is alternately white and dark brownish. } \\
\text { Rivalry of white and a brownish hue. } \\
\text { Rivalry of light grey and very light brown, } \\
\text { brown growing weaker. } \\
\text { Indefinite greyish effect, which passes into a } \\
\text { white. No rivalry. } \\
\text { No rivalry. A uniform pale pea-green. } \\
\text { First white, then green, which remains, but } \\
\text { grows less saturated. } \\
\text { Rivalry of white and blue, which settles into a } \\
\text { white, with a strong tinge of blue. } \\
\text { Rivalry of white and violet. Some colour } \\
\text { always remains around edges. } \\
\text { Strife between white and purple, white greatly } \\
\text { predominating. } \\
\text { Rivalry ; grey at first appears white, later } \\
\text { yellow. Purple appears first as a faint red, } \\
\text { later as a decided purple. }\end{array}$ \\
\hline
\end{tabular}




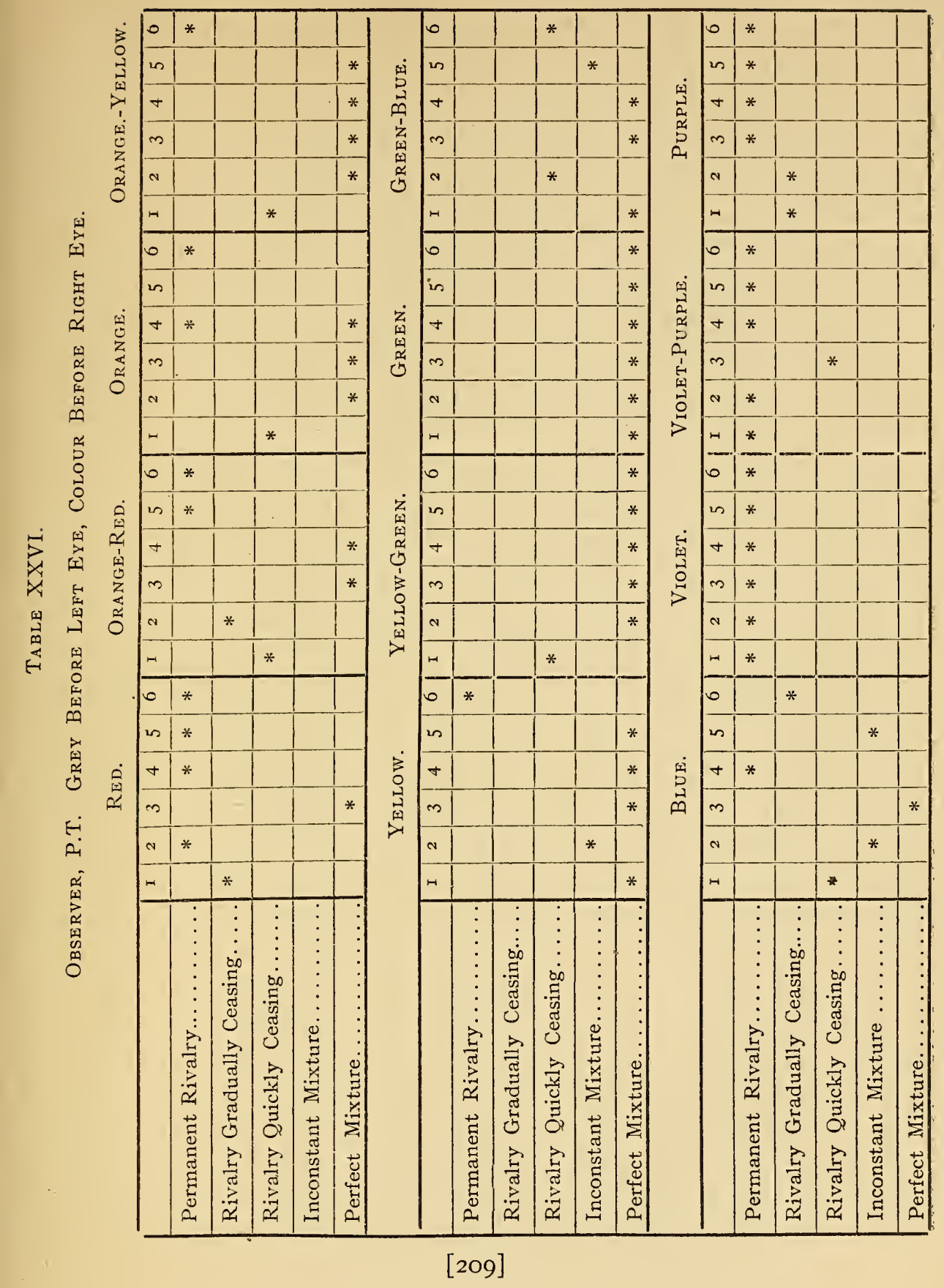




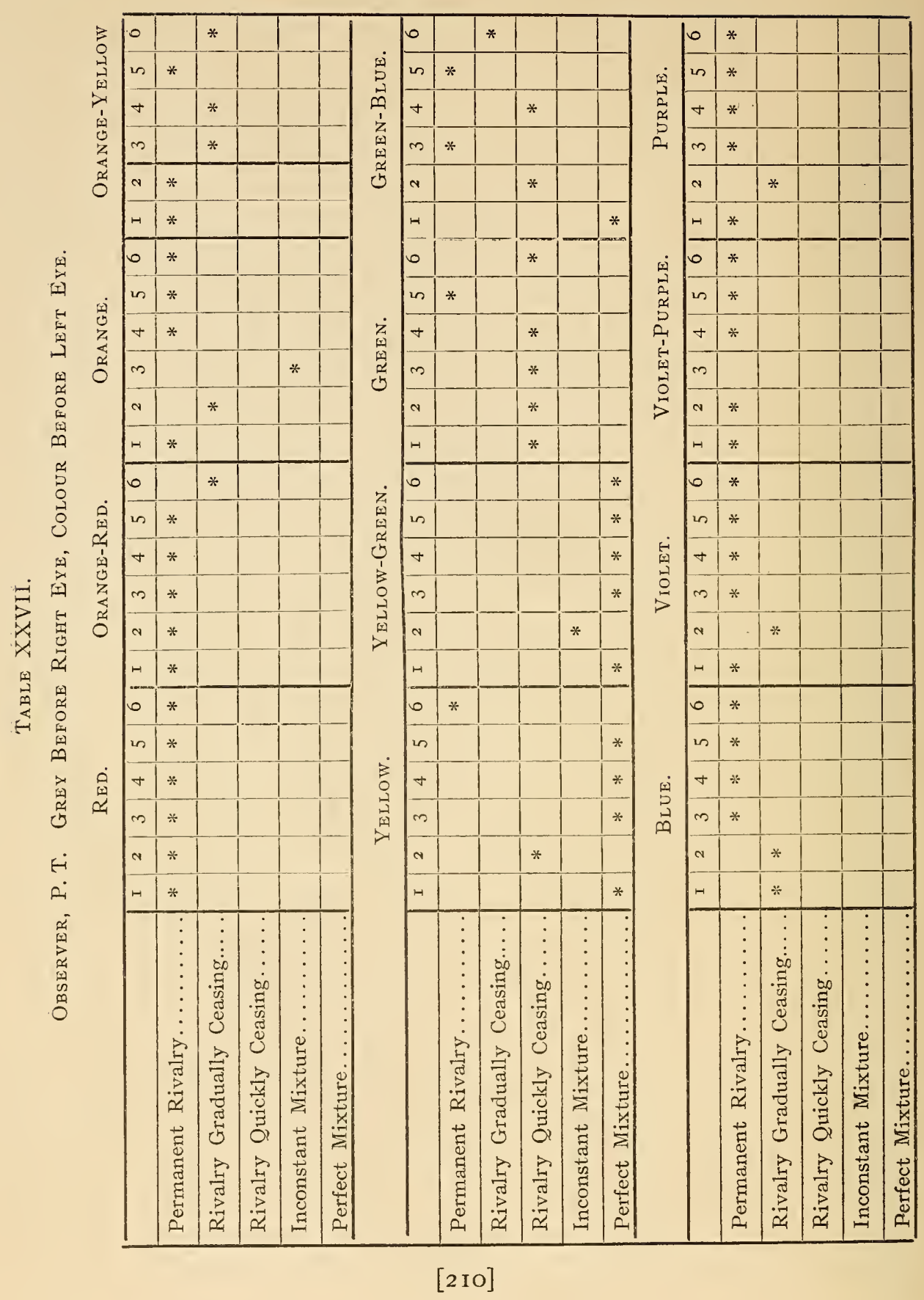



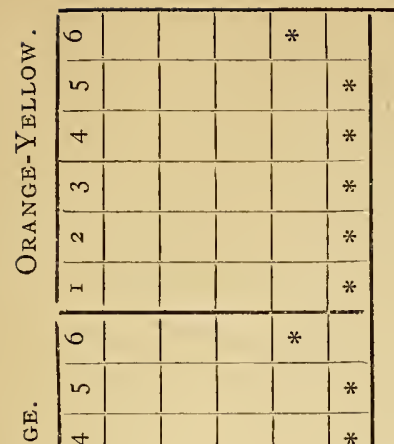

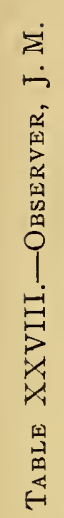


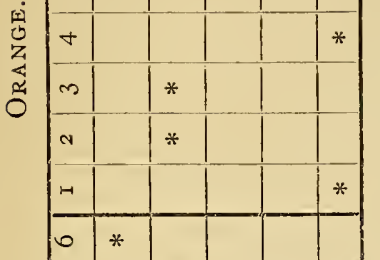

in

+

동

皮

\begin{tabular}{|l|l|}
$a$ & $*$ \\
\hline-1 &
\end{tabular}

$\frac{1}{0 \cdot *}$

in $\mid * \quad$ |

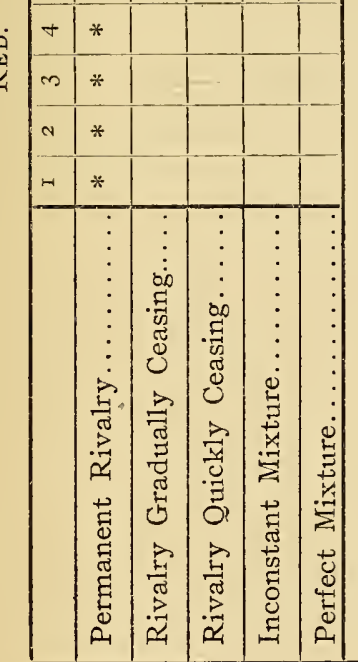

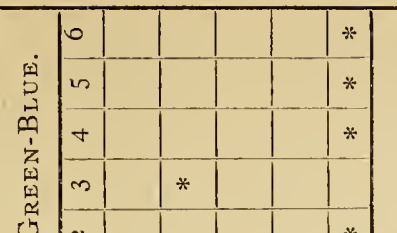

\begin{tabular}{|l|l|l|l|l|l|}
\hline$\rightarrow$ & & & & & $*$ \\
\hline- & & & & &
\end{tabular}

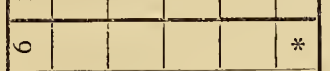

in

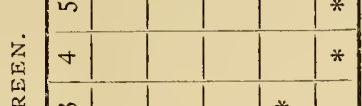

\begin{tabular}{l|l|l|l|}
\hline \multirow{2}{*}{$\infty$} & $m$ & & $*$
\end{tabular}

o

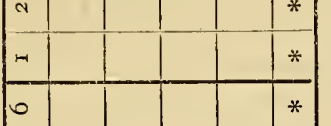

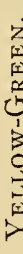

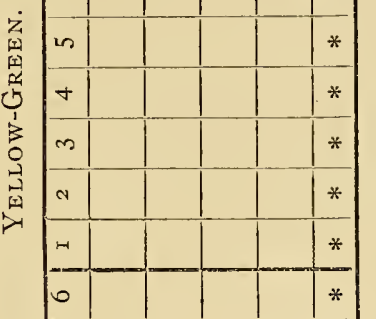

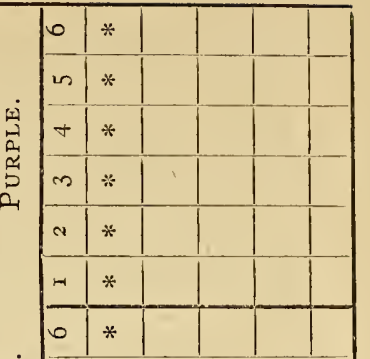

幽的| *

$+x^{\circ}+*$

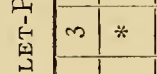

号

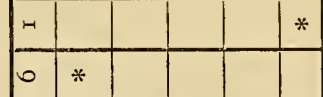

in $*$

$\dot{8}+1 *$

$\stackrel{5}{\circ}$

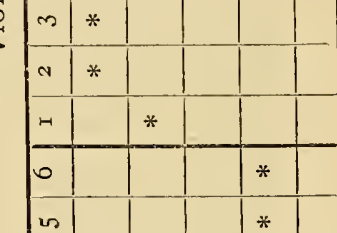

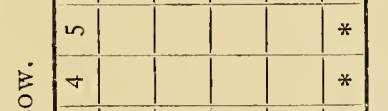

藏

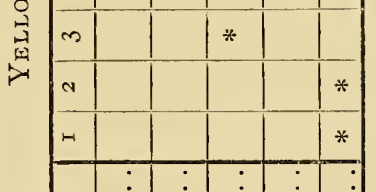

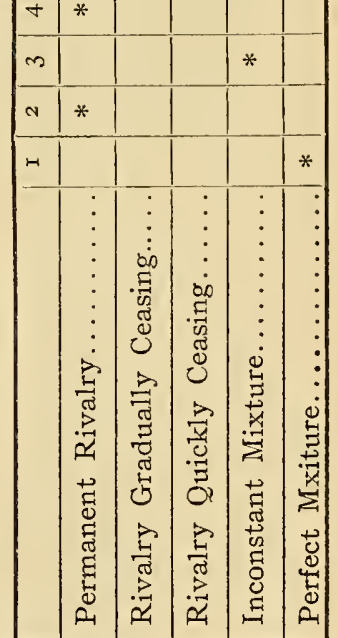

[2I I ] 
Results: $\mathrm{x}$. The character of the rivalry of the visionfields differed in some important respects from that which occurred with two colours. (a) There were no cases of "complete rivalry," i.e., of rivalry of sensations of quite the same character as those in monocular vision. Either the grey was brighter or had some tinge of colour, or the colour was of less saturation or changed in tone, or several or all of these modifications occurred together. (b) Orange-red, orange, and orange-yellow very frequently, and even yellow and purple in some cases, became brown or brownish. This never occurred with red, which when modified appeared less bright, or of lower saturation (i.e., pinkish) or changed to orange-red or orange. It was noticeable that the brown effect came not less frequently with the brighter than with the darker greys. (c) The rivalry, even when very pronounced at first, very frequently subsided more or less quickly into an inconstant, or even a perfect mixture. (d) The phenomena are accordingly classified in the tables in this section upon a different basis from that adopted in the two preceding sections. Instead of the completeness of the rivalry, i.e., the absence of any modification of the competing colours, the criterion is its permanence, or the rapidity with which it subsides. The term "inconstant mixture" has also a slightly different significance from that attached to it in the former tables. There it was extended to include the cases where there was rivalry, sometimes even quite pronounced, but with a mixed colour appearing between the alternating colours. In the present tables it is used only for cases where there was no rivalry, beyond an unsteadiness of the mixed colour.

2. Complete mixture of the impressions was less common than with two colours. This was, of course, to be expected, as in many cases the two colours were much more alike than a coloured and an uncoloured impression.

3. Comparison of the various colours as to the facility with which they mix binocularly with uncoloured light shows that their relative quiescence is not quite the same when they are combined with uncoloured light as when they are combined 
with one another. The regions of most strenuous rivalry, as will be seen by a glance at Curves V to VII, are at the very ends of the spectrum, and the region where most mixture: occurs is about at the middle, the gradation between these: extremes being on the whole quite regular. The colour with which most mixture occurred is in each of the curves shown to be yellow-green. Here the rivalry of the fields was scarcely ever very pronounced, and usually did not occur at all. With violet, violet-purple, and purple, which appear at or near the maximum, the rivalry was not, perhaps, so much more marked than with some other colours, but it was more persistent. The impression did not settle into any one colour so frequently as with other combinations.

4. The greys which mixed best were those of medium brightness. This was the case in spite of the fact that the intensities of the grey and the colour used in each experiment were always carefully equalized by the adjustment of the lamps.

5. The colours mostly tended to become fainter when regarded for a time. In some cases, however, they persisted, and in a few instances they even became more pronounced after a time than at first.

6. In a number of cases with violet, violet-purple and purple the competing grey had a yellow tinge. This occurred both with the deeper and the lighter greys. As, according to the results of Miss Baker, ${ }^{1}$ who used the same colours, violet and yellow-green are about complementary, these are probably to be regarded as cases of binocular contrast.

7. The stereoscopic effect was found to be practically completely preserved in almost every case. The exceptions occurred near the beginning of the experiments when the eyes of the observer, being unused to the conditions, were probably more easily fatigued. When these experiments were repeated later it was found that in every case the stereoscopic effect was complete.

(4) Mixture of colours covering the entire vision-field. The experiments so far reported were all made with surfaces or

1 University of Toronto Studies, Psychological Series, Vol. ii, No.r, p.I6. 
objects covering only a portion of the vision-field, the remainder being darkened. The following experiments were differently arranged, the colours covering the whole of the field of vision, so that not only were the colours more extended spacially, but also the possibility of comparison was lessened. The apparatus consisted simply of a large pair of goggles similar to those worn by automobilists, but with removable glasses. The frames of the goggles were fitted with grooves, closed at the bottom, but left open at the top, into which square glass slides could be easily inserted. The goggles were fitted closely to the face by means of some light fur attached to the back of the frames, so that they could be adjusted with comfort to the observer, and yet exclude all light. They were held snugly in place by an elastic band which went round the head. Two sets of coloured glass slides were used. One was of mineral-dyed glasses, five in number, the colours being red, yellow, green, blue and violet. The other set was composed of coloured gelatine combinations placed between thin sheets of plain glass. These were twelve in number, and divided the entire spectrum into approximately equal sections. Slides of uncoloured plate glass were also used. The spectroscopical analysis of the colours used is as follows :

Spectroscopical Analysis of the Colours Used.

I.-Gelatine Colours.

\begin{tabular}{|c|c|c|c|}
\hline Colour. & $\begin{array}{l}\text { Undiminished in } \\
\text { Intensity. }\end{array}$ & $\begin{array}{l}\text { Somewhat } \\
\text { Weaker. }\end{array}$ & Very Weak. \\
\hline $\operatorname{Red}(\mathrm{I}) \ldots \ldots$ & $720-5^{89}$ & $\ldots \ldots \ldots$ & $500-410$ \\
\hline Orange $(2) \ldots \ldots \ldots$ & $720-580$ & $5^{60}-530$ & $\left\{\begin{array}{l}580-560 \\
470-440\end{array}\right\}$ \\
\hline $\begin{array}{l}\text { Orange-Yellow (3).. } \\
\text { Yellow }(4) \ldots \ldots \ldots\end{array}$ & $\begin{array}{l}720-520 \\
720-500\end{array}$ & $\begin{array}{l}520-510 \\
510-480\end{array}$ & $480-455$ \\
\hline Yellow-Green (5)... & $5^{80}-490$ & $\left\{\begin{array}{l}650-580 \\
490-440\end{array}\right\}$ & \\
\hline Green (6). . & $580-465$ & $\left\{\begin{array}{c}730-680 \\
610-580 \\
465-450\end{array}\right\}$ & $\left\{\begin{array}{l}730-680 \\
450-435\end{array}\right\}$ \\
\hline Green-Blue $(7) \ldots$. & $570-440$ & $\left\{\begin{array}{l}440-425 \\
590-570\end{array}\right\}$ & $730-680$ \\
\hline Blue-Green (8).. & $540-440$ & $\left\{\begin{array}{l}570-540 \\
440-430\end{array}\right\}$ & $730-690$ \\
\hline Blue $(9) \ldots \ldots$ & $530-425$ & $560-530$ & $\left\{\begin{array}{l}425-410 \\
720-665\end{array}\right\}$ \\
\hline Violet (1о).... & $\left.\begin{array}{l}470-V \text {.end } \\
720-650\end{array}\right\}$ & $500-470$ & \\
\hline Violet-Purple (II). . & $\left.\begin{array}{l}510-V . e n d \\
710-620\end{array}\right\}$ & $\left\{\begin{array}{l}620-590 \\
530-510\end{array}\right\}$ & \\
\hline Purple (I2)........ & $720-590$ & $480-V$. end & $590-480$ \\
\hline
\end{tabular}


II.-Mineral Colours.

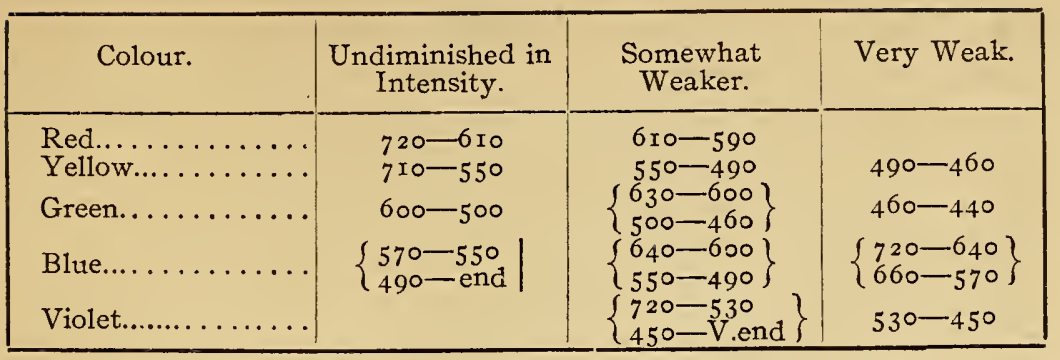

In experimenting, the goggles, without any glasses in, were first adjusted over the observer's eyes. He then closed his eyes, and a pair of differently coloured glasses were slipped into place by the experimenter. The observer was then told to open his eyes, being careful to open both at once, and not at any time to close one eye alone. Observations were then made regarding the colour of objects both within and without the room. In observing objects outside, care had to be exercised to seat the observer before the window so that there should be no interference from the bars of the window sash. If the vertical centre bar of the sash came in the middle of the field it was found that the colours on the two sides were more readily distinguished. The observer was seated at the window at the beginning of the experiments, and looking out reported the appearance of everything in the vision-field generally, i.e., whether darker or brighter than ordinary, or whether there was any definite prevailing colour tone. $\mathrm{He}$ then reported the appearance of prominent objects in the landscape, such as the sky, trees, a bright yellow house with dark green shutters, a red brick outhouse, snow and grass, grey brick and stonework of the University buildings, a slate roof just outside the window. After this some observation was made of objects within the room. Then the observer was handed two large cards, one black and one white, on each of which were arranged in a circle twenty small discs of coloured paper, mostly of the Milton-Bradley series, of approximately equal spectral differences, and he was asked to give his judgment of several of the colours. Then he was asked to raise 
his eyes and tell, as nearly as he was able, what colours were before his eyes. Finally the observer closed his eyes, the goggles were removed and he was then directed to open his eyes, to look with crossed eyes, and to report what after-effect,if any, he saw. Two complete series of experiments were made with the gelatine colours, each for a different observer. In each series one constant colour was employed, with which each of the others was in turn combined. The series, however, was not carried on uninterruptedly, but other combinations were interspersed, so that the observer was not only ignorant of the actual colours of the glasses at any time before his eyes, but was not even aware of any constant colour being used. A series was also made with combinations of mineral-dyed and plain glasses, which was not, however, arranged in any definite order. The results of the three series are given fully in Tables XXIX to XXXI.

Three other observers also made series of experiments, using the six mineral-dyed glasses only. The results of these are not given in extenso, as their general character is similar to the results obtained by the former observers. None of the results lend themselves very readily to tabulation in more condensed form, owing to the irregularity of the effects of the combinations of colours upon the colour of objects in the vision-field. The appended summary of results, however, is based upon the reports of the five observers.

Table XXIX.-Blue-Green (No. 8) Before Right Eye.

\begin{tabular}{|c|c|c|}
\hline $\begin{array}{c}\text { Colour } \\
\text { Before } \\
\text { Left Eye. }\end{array}$ & $\begin{array}{l}\text { Subject of } \\
\text { Report. }\end{array}$ & Results. \\
\hline \multirow{4}{*}{$\begin{array}{l}\text { Red } \\
(\text { No. I })\end{array}$} & $\begin{array}{l}\text { Colour of } \\
\text { Surrounding } \\
\text { Objects. }\end{array}$ & $\begin{array}{l}\text { Everything looked red and brighter than nor- } \\
\text { mally. Red brick wall appeared brighter red. } \\
\text { The hands had a suggestion of yellow over them } \\
\text { There was no rivalry of the vision fields. }\end{array}$ \\
\hline & $\begin{array}{l}\text { Colours on } \\
\text { Card. }\end{array}$ & $\begin{array}{l}\text { No good green seen at all. No. I } 5 \text { (a dark blue) is } \\
\text { the only good blue. }\end{array}$ \\
\hline & $\begin{array}{l}\text { Colour of } \\
\text { Glasses. }\end{array}$ & Cannot tell what colours. \\
\hline & $\begin{array}{l}\text { After-Effect } \\
\text { With Crossed } \\
\text { Eyes. }\end{array}$ & From right eye red, from left greenish. \\
\hline
\end{tabular}


Table XXIX-(Continued).

\begin{tabular}{|c|c|c|}
\hline $\begin{array}{c}\text { Colour } \\
\text { Before } \\
\text { Left Eye. }\end{array}$ & $\begin{array}{l}\text { Subject of } \\
\text { Report. }\end{array}$ & Results. \\
\hline \multirow{4}{*}{$\begin{array}{l}\text { Orange } \\
\text { (No. 2) }\end{array}$} & $\begin{array}{l}\text { Colour of } \\
\text { Surrounding } \\
\text { Objects. }\end{array}$ & Everything appeared a little darker. \\
\hline & $\begin{array}{l}\text { Colours on } \\
\text { Card. }\end{array}$ & $\begin{array}{l}\text { No good green or blue. Nos. } 2 \text { and } 3 \text { (dark and } \\
\text { light red) had lustre. }\end{array}$ \\
\hline & $\begin{array}{l}\text { Colour of } \\
\text { Glasses. }\end{array}$ & Yellow on right side and blue on left. \\
\hline & $\begin{array}{l}\text { After-Effect } \\
\text { With Crossed } \\
\text { Eyes. }\end{array}$ & From right eye bluish, from left eye no colour. \\
\hline \multirow{4}{*}{$\begin{array}{l}\text { Orange- } \\
\text { Yellow } \\
\text { (No 3) }\end{array}$} & $\begin{array}{l}\text { Colour of } \\
\text { Surrounding } \\
\text { Objects. }\end{array}$ & $\begin{array}{l}\text { (This experiment was performed on a dark day.) } \\
\text { Everything much darker. Yellow painted } \\
\text { house had lost its yellow colour. Slight rivalry } \\
\text { between yellow-green and violet. Snow had } \\
\text { a yellow-green tinge. Trees and stone sills of } \\
\text { buildings were tinged with violet, dingy white } \\
\text { brick appeared purplish. }\end{array}$ \\
\hline & $\begin{array}{l}\text { Colours on } \\
\text { Card. }\end{array}$ & $\begin{array}{l}\text { No good blue. Nos. } x, 2,3,4 \text { and } 5 \text { had lustre. } \\
\text { r } 8 \text { and } 19 \text { (violet and violet-purple) were } \\
\text { brown with slight suggestion of violet. }\end{array}$ \\
\hline & $\begin{array}{l}\text { Colour of } \\
\text { Glasses. }\end{array}$ & $\begin{array}{l}\text { Could not tell at end of experiment, but from } \\
\text { memory of first impressions judged violet on } \\
\text { left and yellow-green on right. }\end{array}$ \\
\hline & $\begin{array}{l}\text { After-Effect } \\
\text { With Crossed } \\
\text { Eyes. }\end{array}$ & From right eye blue, from left no colour. \\
\hline \multirow{4}{*}{$\begin{array}{l}\text { Yellow } \\
\text { (No. 4) }\end{array}$} & $\begin{array}{l}\text { Colour of } \\
\text { Surrounding } \\
\text { Objects. }\end{array}$ & $\begin{array}{l}\text { Red brick building looked redder than it was } \\
\text { remembered. Sky was blue-green. Yellow } \\
\text { house was a mixture of yellow and pink. } \\
\text { Hands and face of experimenter looked ghastly, } \\
\text { with violet tinge around edges. Everything } \\
\text { a little darker. }\end{array}$ \\
\hline & $\begin{array}{l}\text { Colours on } \\
\text { Card. }\end{array}$ & $\begin{array}{l}\text { No red. Red and orange discs appeared choco- } \\
\text { late. } 6 \text { and } 7 \text { (orange-yellow and yellow- } \\
\text { orange) were good browns. I } 7 \text {, ind and (blue- } 8 \text { and } \\
\text { violet, violet, and violet-purple) were dark } \\
\text { grey with a tinge of violet. }\end{array}$ \\
\hline & $\begin{array}{l}\text { Colour of } \\
\text { Glasses. }\end{array}$ & Blue on right, green on left. \\
\hline & $\begin{array}{l}\text { After-Effect } \\
\text { With Crossed } \\
\text { Eyes. }\end{array}$ & From right eye blue, from left no colour. \\
\hline
\end{tabular}


RobINSON : STEREOSCOPIC VISION

Table XXIX-(Continued).

\begin{tabular}{|c|c|c|}
\hline $\begin{array}{l}\text { Colour } \\
\text { Before } \\
\text { Left Eye. }\end{array}$ & $\begin{array}{l}\text { Subject of } \\
\text { Report. }\end{array}$ & Results. \\
\hline \multirow{4}{*}{$\begin{array}{l}\text { Yellow- } \\
\text { Green } \\
\text { (No. 5) }\end{array}$} & $\begin{array}{l}\text { Colour of } \\
\text { Surrounding } \\
\text { Objects. }\end{array}$ & $\begin{array}{l}\text { Everything a little darker. Yellow house ap- } \\
\text { peared dirty yellow with a little green. Sky } \\
\text { bluish-green. Face pallid, lips almost colour- } \\
\text { less. Not the least rivalry. }\end{array}$ \\
\hline & $\begin{array}{l}\text { Colours on } \\
\text { Card. }\end{array}$ & $\begin{array}{l}\text { No red. Red and orange appeared dark brown } \\
\text { or chocolate. No. I } 4 \text { (blue-green) appeared } \\
\text { bluish-grey. }\end{array}$ \\
\hline & $\begin{array}{l}\text { Colour of } \\
\text { Glasses. }\end{array}$ & Bluish on right, green on left. \\
\hline & $\begin{array}{l}\text { After-Effect } \\
\text { With Crossed } \\
\text { Eyes. }\end{array}$ & From right eye purplish, from left eye brownish. \\
\hline \multirow{4}{*}{$\begin{array}{c}\text { Green } \\
(\text { No. 6) }\end{array}$} & $\begin{array}{l}\text { Colour of } \\
\text { Surrounding } \\
\text { Objects. }\end{array}$ & $\begin{array}{l}\text { (No sun shining). Everything dark. Snow } \\
\text { greenish. Yellow house appeared dirty yellow } \\
\text { with a little green. Sky bluish-green. Face } \\
\text { pallid, lips almost colourless. Not the least } \\
\text { rivalry. }\end{array}$ \\
\hline & $\begin{array}{l}\text { Colours on } \\
\text { Card. }\end{array}$ & No red. Reds were brown or chocolate. \\
\hline & $\begin{array}{l}\text { Colour of } \\
\text { Glasses. }\end{array}$ & Could not tell at all.. \\
\hline & $\begin{array}{l}\text { After-Fffect } \\
\text { With Crossed } \\
\text { Eyes. }\end{array}$ & From right eye purple, from left no colour. \\
\hline \multirow{3}{*}{$\begin{array}{l}\text { Green- } \\
\text { Blue } \\
\text { (No. 7) }\end{array}$} & $\begin{array}{l}\text { Colour of } \\
\text { Surrounding } \\
\text { Ojects. }\end{array}$ & $\begin{array}{l}\text { Everything darker. Red brick wall greyish. } \\
\text { Snow darker than usual. Sky had leaden } \\
\text { appearance. Hand looked darker than usual } \\
\text { with greenish lustre around edge. }\end{array}$ \\
\hline & $\begin{array}{l}\text { Colours on } \\
\text { Card. }\end{array}$ & $\begin{array}{l}\text { No red. Reds were dark brown. No. I } 3 \text { (very } \\
\text { greenish-blue) almost colourless. }\end{array}$ \\
\hline & $\begin{array}{l}\text { Colour of } \\
\text { Glasses. }\end{array}$ & Blue, but could not distinguish sides. \\
\hline \multirow{4}{*}{$\begin{array}{c}\text { Blue } \\
\text { (No. 9) }\end{array}$} & $\begin{array}{l}\text { Colour of } \\
\text { Surrounding } \\
\text { Objects. }\end{array}$ & $\begin{array}{l}\text { Yellow house looked pink. White and red brick } \\
\text { both appeared red. Snow and sky looked } \\
\text { blue. Face pallid, and no colour in lips at all. }\end{array}$ \\
\hline & $\begin{array}{l}\text { Colours on } \\
\text { Card. }\end{array}$ & $\begin{array}{l}\text { Nos. } 2-5 \text { dark reddish-brown. No yellow on } \\
\text { card. } 6 \text { and } 7 \text { (orange-yellow and yellow- } \\
\text { orange) were dark brown. No. } 9 \text { (green- } \\
\text { yellow) was pink. } 8 \text { and Io (yellow and yel- } \\
\text { low-green) were dark brown. I I and I2 } \\
\text { (green) were dark grey. }\end{array}$ \\
\hline & $\begin{array}{l}\text { Colour of } \\
\text { Glasses. }\end{array}$ & Blue on right. Could not tell what colour on left. \\
\hline & $\begin{array}{l}\text { After-Effect } \\
\text { With Crossed } \\
\text { Eyes. }\end{array}$ & From right eye green, from left no colour. \\
\hline
\end{tabular}


Table XXIX-(Continued).

\begin{tabular}{|c|c|c|}
\hline $\begin{array}{l}\text { Colour } \\
\text { B } \in \text { fore } \\
\text { Left Eye. }\end{array}$ & $\begin{array}{l}\text { Subject of } \\
\text { Report. }\end{array}$ & Results. \\
\hline \multirow{4}{*}{$\begin{array}{l}\text { Violet } \\
\text { (No. I0) }\end{array}$} & $\begin{array}{l}\text { Colour of } \\
\text { Surrounding } \\
\text { Objects. }\end{array}$ & $\begin{array}{l}\text { Everything very dark. Red brick wall fiery red. } \\
\text { Sky dark blue. Yellow wall had pinkish tinge. } \\
\text { Hands were purplish. }\end{array}$ \\
\hline & $\begin{array}{l}\text { Colours on } \\
\text { Card. }\end{array}$ & $\begin{array}{l}6,7 \text { and } 8 \text { (orange-yellow and yellow) varied } \\
\text { between red and yellow. } 2,3 \text { and } 5 \text { (red and } \\
\text { orange) were very brilliant reds. } 4 \text { (orange- } \\
\text { red) was a beautiful pink. }\end{array}$ \\
\hline & $\begin{array}{l}\text { Colour of } \\
\text { Glasses. }\end{array}$ & Blue on left, on right could not tell. \\
\hline & $\begin{array}{l}\text { After-Effect } \\
\text { With Crossed } \\
\text { Eyes. }\end{array}$ & From right eye greenish, from left eye red. \\
\hline \multirow{4}{*}{$\begin{array}{l}\text { Violet- } \\
\text { Purple } \\
\text { (No. I I) }\end{array}$} & $\begin{array}{l}\text { Colour of } \\
\text { Surrounding } \\
\text { Objects. }\end{array}$ & $\begin{array}{l}\text { Everything had purple tinge, and was much } \\
\text { darker. Snow was bluish, hands reddish. }\end{array}$ \\
\hline & $\begin{array}{l}\text { Colours on } \\
\text { Card. }\end{array}$ & No good red, yellow or blue. \\
\hline & $\begin{array}{l}\text { Colour of } \\
\text { Glasses. }\end{array}$ & Left, blue or violet ; right, could not tell. \\
\hline & $\begin{array}{c}\text { After-Effect } \\
\text { With Crossed } \\
\text { Eyes. }\end{array}$ & From right eye faint red, from left eye green. \\
\hline \multirow{4}{*}{$\begin{array}{l}\text { Purple } \\
\text { (No. 1 2) }\end{array}$} & $\begin{array}{l}\text { Colour of } \\
\text { Surrounding } \\
\text { Objects. }\end{array}$ & $\begin{array}{l}\text { Shadows from trees and buildings were purple- } \\
\text { violet. Everything darker. Sky pink and } \\
\text { blue. Yellow house appeared as without } \\
\text { glasses. Red brick wall had some yellow in it. }\end{array}$ \\
\hline & $\begin{array}{l}\text { Colours on } \\
\text { Card. }\end{array}$ & $\begin{array}{l}\text { Green entirely absent. Nos. } 2 \text { and } 4 \text { had slight } \\
\text { lustre. No. 9 (green-yellow) appeared white. } \\
\text { No. I3 (green-blue) appeared grey with a sug- } \\
\text { gestion of blue. }\end{array}$ \\
\hline & $\begin{array}{l}\text { Colour of } \\
\text { Glasses. }\end{array}$ & Blue on right, purple on left. \\
\hline & $\begin{array}{c}\text { After-Effect } \\
\text { With Crossed } \\
\text { Eyes. }\end{array}$ & From right eye green, from left eye brown. \\
\hline
\end{tabular}


Table XXX.-Yellow-Green (No. 5) Before Left Eye.

\begin{tabular}{|c|c|c|}
\hline $\begin{array}{c}\text { Colour } \\
\text { Before } \\
\text { Right Eye }\end{array}$ & $\begin{array}{c}\text { Subject } \\
\text { of Report. }\end{array}$ & Results. \\
\hline \multirow{4}{*}{$\begin{array}{l}\text { Red } \\
\text { (No. I) }\end{array}$} & $\begin{array}{l}\text { Colour of } \\
\text { Surrounding } \\
\text { Objects. }\end{array}$ & $\begin{array}{l}\text { Whole vision field darker. Slight rivalry of green } \\
\text { and pink, but green soon entirely disappeared. } \\
\text { Dark yellow or brown leaves appeared bright } \\
\text { yellow. Yellow house brighter. Green lines } \\
\text { of note-book were purple. Sky had a purplish } \\
\text { tinge, and darker than usual. }\end{array}$ \\
\hline & $\begin{array}{l}\text { Colours on } \\
\text { Card. }\end{array}$ & $\begin{array}{l}\text { Yellows less saturated. Most of the colours } \\
\text { purplish. }\end{array}$ \\
\hline & $\begin{array}{l}\text { Colour of } \\
\text { Glasses. }\end{array}$ & $\begin{array}{l}\text { On right, purple, on left, could not tell, but } \\
\text { thought yellow. }\end{array}$ \\
\hline & $\begin{array}{c}\text { After Effect } \\
\text { With Crossed } \\
\text { Eyes. }\end{array}$ & From right eye faint red, from left, green. \\
\hline \multirow{4}{*}{$\begin{array}{l}\text { Orange } \\
(\text { No. 2) }\end{array}$} & $\begin{array}{l}\text { Colour of } \\
\text { Surrounding } \\
\text { Objects. }\end{array}$ & $\begin{array}{l}\text { Everything darker. Some rivalry at first. Later, } \\
\text { colours blended, and appeared something } \\
\text { between red and purple. Yellow house was } \\
\text { lighter yellow. }\end{array}$ \\
\hline & $\begin{array}{l}\text { Colours on } \\
\text { Card. }\end{array}$ & $\begin{array}{l}\text { I8, I9, and } 20 \text { (violet, violet-purple and purple) } \\
\text { had nearly lost their violet or purple tone, and } \\
\text { were of a dingy hue. No. } 6 \text { (orange-yellow) } \\
\text { was between brown and dark yellow. }\end{array}$ \\
\hline & $\begin{array}{l}\text { Colour of } \\
\text { Glasses. }\end{array}$ & On right violet, on left could not say. \\
\hline & $\begin{array}{c}\text { After-Effect } \\
\text { With Crossed } \\
\text { Eyes. }\end{array}$ & From right eye violet, from left no colour. \\
\hline \multirow{4}{*}{$\begin{array}{l}\text { Orange } \\
\text { Yellow } \\
\text { (No. 3) }\end{array}$} & $\begin{array}{l}\text { Colour of } \\
\text { Surrounding } \\
\text { Objects. }\end{array}$ & $\begin{array}{l}\text { (Sun shining brightly). Everything has a yellow } \\
\text { tint. Slight rivalry at first, but soon ceased. } \\
\text { Green fir-tree dark green, but more yellow- } \\
\text { green where sun shines on it. Red brick wall } \\
\text { appeared dull reddish-brown. }\end{array}$ \\
\hline & $\begin{array}{l}\text { Colours on } \\
\text { Card. }\end{array}$ & Greens nearer yellow. Blues more purplish. \\
\hline & $\begin{array}{l}\text { Colour of } \\
\text { Glasses. }\end{array}$ & $\begin{array}{l}\text { Slight yellow tinge. Could not distinguish } \\
\text { between the two sides. }\end{array}$ \\
\hline & After-Effect. & None from either eye. \\
\hline \multirow{3}{*}{$\begin{array}{l}\text { Yellow } \\
\text { (No. 4) }\end{array}$} & $\begin{array}{l}\text { Colour of } \\
\text { Surrounding } \\
\text { Objects. }\end{array}$ & $\begin{array}{l}\text { Everything had bright yellow tint. Yellow } \\
\text { house as usual. No rivalry. }\end{array}$ \\
\hline & $\begin{array}{l}\text { Colours on } \\
\text { Card. }\end{array}$ & $\begin{array}{l}\text { Greens more bluish. Nos. } 2 \text { and } 3 \text { had slight } \\
\text { lustre. }\end{array}$ \\
\hline & $\begin{array}{l}\text { Colour of } \\
\text { Glasses. }\end{array}$ & Both eyes had yellow glasses. \\
\hline
\end{tabular}


RoBINSON : STEREOSCOPIC VISION

TAble XXX-(Continued)

\begin{tabular}{|c|c|c|}
\hline $\begin{array}{l}\text { Colour } \\
\text { Before } \\
\text { Right Eye }\end{array}$ & $\begin{array}{l}\text { Subject of } \\
\text { Report. }\end{array}$ & Results, \\
\hline \multirow{4}{*}{$\begin{array}{l}\text { Green } \\
\text { (No. 6) }\end{array}$} & $\begin{array}{l}\text { Colour of } \\
\text { Surrounding } \\
\text { Objects. }\end{array}$ & Sky dark blue. Hand pallid. \\
\hline & $\begin{array}{l}\text { Colours on } \\
\text { Cards. }\end{array}$ & $\begin{array}{l}\text { Red and orange appeared brownish. Two cards, } \\
\text { one black, the other white, with the same colours } \\
\text { on, being shown, the colours were observed to } \\
\text { show up better on the dark card. }\end{array}$ \\
\hline & $\begin{array}{l}\text { Colour of } \\
\text { Glasses. }\end{array}$ & On the right side light blue, on left, yellow. \\
\hline & After-Effect & From right side a slight pink, from left side yellow. \\
\hline \multirow{4}{*}{$\begin{array}{l}\text { Green- } \\
\text { Blue } \\
\text { (No. 7) }\end{array}$} & $\begin{array}{l}\text { Colour of } \\
\text { Surrounding } \\
\text { Objects. }\end{array}$ & $\begin{array}{l}\text { (Experiment performed in bright sunshine.) } \\
\text { Everything tinged with yellow-green, and } \\
\text { seems dull. Yellow house appears as usual. } \\
\text { Cannot distinguish red bricks of the barn as red. }\end{array}$ \\
\hline & $\begin{array}{l}\text { Colours on } \\
\text { Card. }\end{array}$ & Discrimination much the same as without glasses. \\
\hline & $\begin{array}{l}\text { Colour of } \\
\text { Glasses. }\end{array}$ & $\begin{array}{l}\text { Could not say decidedly, but had a vague impres- } \\
\text { sion of green. }\end{array}$ \\
\hline & After-Effect. & No after-effect. \\
\hline \multirow{4}{*}{$\begin{array}{l}\text { Blue } \\
\text { Green } \\
\text { (No. 8) }\end{array}$} & $\begin{array}{l}\text { Colour of } \\
\text { Surrounding } \\
\text { Objects. }\end{array}$ & $\begin{array}{l}\text { Everything much darker, and had a slight yellow } \\
\text { tinge. Yellow house was quite yellow. Snow } \\
\text { where sun shining on it was bluish. }\end{array}$ \\
\hline & $\begin{array}{l}\text { Colours on } \\
\text { Card. }\end{array}$ & $\begin{array}{l}\text { Reds appeared dark brown, so dark as to be almost } \\
\text { without colour. }\end{array}$ \\
\hline & $\begin{array}{l}\text { Colour of } \\
\text { Glasses. }\end{array}$ & Blue on right, yellow on left. \\
\hline & After-Effect. & $\begin{array}{l}\text { From left eye violet. No after-effect from right } \\
\text { eye. }\end{array}$ \\
\hline \multirow{4}{*}{$\begin{array}{l}\text { Blue } \\
(\text { No. 9) }\end{array}$} & $\begin{array}{l}\text { Colour of } \\
\text { Surrounding } \\
\text { Objects. }\end{array}$ & $\begin{array}{l}\text { At first slight rivalry between blue and green, } \\
\text { which soon ceased. Snow and yellow building } \\
\text { had normal appearance. Sky appeared dark } \\
\text { blue. (It was really light blue-grey.) Hand } \\
\text { had a pallid appearance. }\end{array}$ \\
\hline & $\begin{array}{l}\text { Colours on } \\
\text { Card. }\end{array}$ & $\begin{array}{l}\text { No. } 2 \text { appeared dark brown. No. I dark dirty } \\
\text { brown. No good red. I I and I } 2 \text { (green) were } \\
\text { blue-green. }\end{array}$ \\
\hline & $\begin{array}{l}\text { Colour of } \\
\text { Glasses. }\end{array}$ & $\begin{array}{l}\text { Could not tell what colours he had on his eyes, but } \\
\text { there seemed a tinge of blue over the vision- } \\
\text { field. }\end{array}$ \\
\hline & After-Effect. & No after-effect. \\
\hline
\end{tabular}


ROBINSON : STEREOSCOPIC VISION

Table XXX-(Continued).

\begin{tabular}{|c|c|c|}
\hline $\begin{array}{l}\text { Colour } \\
\text { Bafore } \\
\text { Right Eye }\end{array}$ & $\begin{array}{l}\text { Subject of } \\
\text { Report. }\end{array}$ & Results. \\
\hline \multirow[t]{4}{*}{$\begin{array}{c}\text { Violet } \\
\text { (No. Io) }\end{array}$} & $\begin{array}{l}\text { Colour of } \\
\text { Surrounding } \\
\text { Objects. }\end{array}$ & $\begin{array}{l}\text { Everything had a hazy appearance with a little } \\
\text { violet tinge. Yellow leaves seemed very bright } \\
\text { yellow. Yellow house had a slight tinge of } \\
\text { green. Hands looked a little darker than } \\
\text { usual. Occasionally, looking past the edge of } \\
\text { any object, e.g., chimney, there appeared a } \\
\text { purplish tinge approaching red. The violet } \\
\text { tinge to everything disappeared and again re-ap- } \\
\text { peared. On its reappearance, the hands had a } \\
\text { distinct purple tinge, and experimenter's lips } \\
\text { were slightly blue. }\end{array}$ \\
\hline & $\begin{array}{l}\text { Colours on } \\
\text { Card. }\end{array}$ & $\begin{array}{l}\text { No. I2 (green) was yellow with slight greenish } \\
\text { tendency. No. I7 (blue-violet) was "dark } \\
\text { blue." }\end{array}$ \\
\hline & $\begin{array}{l}\text { Colour of } \\
\text { Glasses. }\end{array}$ & On right, light blue, on left could not tell. \\
\hline & After-Effect. & Violet from left eye, no effect from right eye. \\
\hline \multirow{4}{*}{$\begin{array}{l}\text { Purple. } \\
\text { (No. I 2) }\end{array}$} & $\begin{array}{l}\text { Colour of } \\
\text { Surrounding } \\
\text { Objects. }\end{array}$ & $\begin{array}{l}\text { (Experiment performed on a dull day.) A } \\
\text { purplish tinge over everything, gradually grow- } \\
\text { ing lighter ; right side a little darker than left. } \\
\text { Dark yellow leaves appeared bright yellow. } \\
\text { Face looked death-like, lips as though almost } \\
\text { bloodless. }\end{array}$ \\
\hline & $\begin{array}{l}\text { Colours on } \\
\text { Card. }\end{array}$ & $\begin{array}{l}\text { No. I appeared bronze or brownish-orange. No. } \\
\text { Io (yellow-green) was a pale yellow. No. } 12 \\
\text { (green) was yellowish-blue. Slight lustre from } \\
\text { Nos. } 2 \text { and } 3 \text {. }\end{array}$ \\
\hline & $\begin{array}{l}\text { Colour of } \\
\text { Glasses. }\end{array}$ & On right, light pink, on left, very light pink. \\
\hline & After-Effect. & No after-effect. \\
\hline
\end{tabular}


TABLE XXXI.

\begin{tabular}{|c|c|c|c|}
\hline \multicolumn{2}{|c|}{ Colour. } & \multirow{2}{*}{$\begin{array}{l}\text { Subject of } \\
\text { Report. }\end{array}$} & \multirow{2}{*}{ Results. } \\
\hline $\begin{array}{l}\text { Right } \\
\text { Eye. }\end{array}$ & $\begin{array}{l}\text { Left } \\
\text { Eye. }\end{array}$ & & \\
\hline \multirow[t]{3}{*}{ 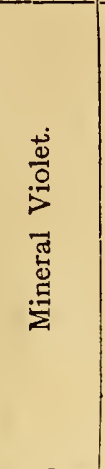 } & \multirow[t]{3}{*}{ 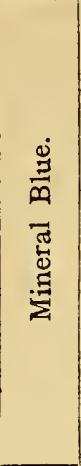 } & $\begin{array}{l}\text { Colour of } \\
\text { Surrounding } \\
\text { Objects. }\end{array}$ & $\begin{array}{l}\text { The whole vision-field had a purplish tinge, } \\
\text { and the light was dimmer. Grass where } \\
\text { sun shone on it was more yellowish than } \\
\text { usual. The evergreen tree was almost } \\
\text { black. The relation of white and yellow in } \\
\text { the yellow house (cornice, etc., white) was } \\
\text { about normal, the colour being darker than } \\
\text { remembered. Sky appeared purplish, the } \\
\text { colour being more prominent on suddenly } \\
\text { turning to look up at it. Hands had an } \\
\text { unnatural appearance, hardly describable. }\end{array}$ \\
\hline & & $\begin{array}{l}\text { Colour of } \\
\text { Glasses. }\end{array}$ & Cannot tell anything about colour of glasses. \\
\hline & & After-Effect. & Very bright, but no after-image. \\
\hline \multirow{4}{*}{ 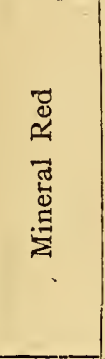 } & \multirow{4}{*}{ 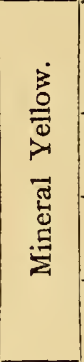 } & $\begin{array}{c}\text { Colour of } \\
\text { Surrounding } \\
\text { Objects. }\end{array}$ & $\begin{array}{l}\text { Sky seemed a brownish-red, getting darker. } \\
\text { Yellow leaves seemed dark brown in centre. }\end{array}$ \\
\hline & & $\begin{array}{l}\text { Colours on . } \\
\text { Card. }\end{array}$ & $\begin{array}{l}\text { No. } 20 \text { (purple) was purplish-red. II (green) } \\
\text { was normal. }\end{array}$ \\
\hline & & $\begin{array}{l}\text { Colour of } \\
\text { Glasses. }\end{array}$ & On right a shade of red, on left, green. \\
\hline & & After-Effect. & $\begin{array}{l}\text { Indefinite impression of colour, quickly dis- } \\
\text { appearing. No distinction between the sides. }\end{array}$ \\
\hline \multirow{4}{*}{ 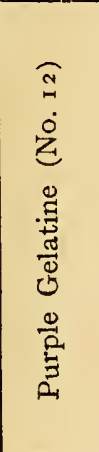 } & \multirow{4}{*}{ 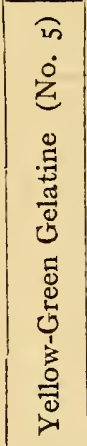 } & $\begin{array}{l}\text { Colour of } \\
\text { Surrounding } \\
\text { Objects. }\end{array}$ & $\begin{array}{l}\text { This experiment was performed on a dark day. } \\
\text { There was a pinkish tinge gradually growing } \\
\text { lighter, the right eye being a little darker } \\
\text { than the other. The dark yellow leaves } \\
\text { appear light yellow. The experimenter's } \\
\text { face appeared corpse-like, the lips bloodless. }\end{array}$ \\
\hline & & $\begin{array}{l}\text { Colours on } \\
\text { Card. }\end{array}$ & Nos. 2 and 3 had lustre. \\
\hline & & $\begin{array}{l}\text { Colour of } \\
\text { Glasses. }\end{array}$ & $\begin{array}{l}\text { On right eye light pink, on left, very light } \\
\text { pink. }\end{array}$ \\
\hline & & After-Effect. & $\begin{array}{l}\text { Only effect is that on removing glasses every- } \\
\text { thing is brighter. }\end{array}$ \\
\hline 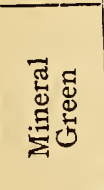 & 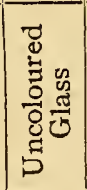 & $\begin{array}{c}\text { Colour of } \\
\text { Surrounding } \\
\text { Objects. }\end{array}$ & $\begin{array}{l}\text { This experiment was performed on a dull day. } \\
\text { On opening the eyes the right eye seemed to } \\
\text { have a shade of yellow, the left having a very } \\
\text { slight tinge of the same colour. The effect } \\
\text { on the right eye seemed to be growing } \\
\text { weaker. }\end{array}$ \\
\hline
\end{tabular}


TABLE XXXI.-ContinUed.

\begin{tabular}{|c|c|c|c|}
\hline \multicolumn{2}{|c|}{ Colour. } & \multirow{2}{*}{$\begin{array}{l}\text { Subject of } \\
\text { Report. }\end{array}$} & \multirow{2}{*}{ Results. } \\
\hline $\begin{array}{l}\text { Right } \\
\text { Eye. }\end{array}$ & $\begin{array}{l}\text { Left } \\
\text { Eye. }\end{array}$ & & \\
\hline \multirow{2}{*}{ 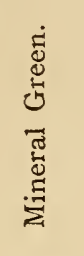 } & \multirow{2}{*}{ 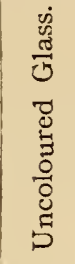 } & $\begin{array}{l}\text { Colour of } \\
\text { Glasses. }\end{array}$ & $\begin{array}{l}\text { In right eye light yellow, in left very indefinite, } \\
\text { and could not tell what colour, if any. }\end{array}$ \\
\hline & & After-Effect. & $\begin{array}{l}\text { After removing glasses and blinking, very } \\
\text { faint tinge of purple (negative after-image). }\end{array}$ \\
\hline \multirow{3}{*}{ 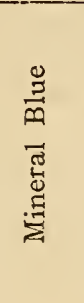 } & \multirow{3}{*}{ 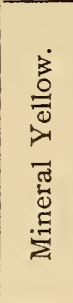 } & $\begin{array}{l}\text { Colour of } \\
\text { Surrounding } \\
\text { Objects. }\end{array}$ & $\begin{array}{l}\text { On opening the eyes the vision-field seemed } \\
\text { somewhat darkened. Rivalry of yellow } \\
\text { and blue followed. }\end{array}$ \\
\hline & & $\begin{array}{l}\text { Colours on } \\
\text { Card. }\end{array}$ & $\begin{array}{l}\text { No. I } 3 \text { (green-blue) was a pale blue, but with } \\
\text { no green in it. No. I } 3 \text { (a green near to } \\
\text { yellow) was quite yellow. }\end{array}$ \\
\hline & & $\begin{array}{l}\text { Colour of } \\
\text { Glasses. }\end{array}$ & On right violet or blue, on left, cannot tell. \\
\hline \multirow{3}{*}{ 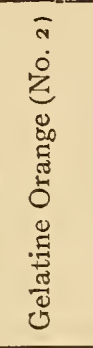 } & \multirow{3}{*}{ 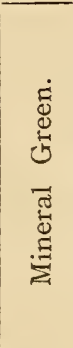 } & $\begin{array}{l}\text { Colour of } \\
\text { Surrounding } \\
\text { Objects. }\end{array}$ & $\begin{array}{l}\text { Everything appeared brighter, with pink } \\
\text { shade. The yellow house is rather a dark } \\
\text { yellow. The colour of the (green) shutters } \\
\text { could not be determined. The experi- } \\
\text { menter's face had a bluish tinge, as if cold. }\end{array}$ \\
\hline & & $\begin{array}{l}\text { Colours on } \\
\text { Card. }\end{array}$ & $\begin{array}{l}\text { Reds had lustre effect. No. Io (yellow-green) } \\
\text { was "light green." No. I } 3 \text { (green-blue) } \\
\text { was a greyish blue. }\end{array}$ \\
\hline & & $\begin{array}{l}\text { Colour of } \\
\text { Glasses. }\end{array}$ & On right eye blue, on left, green. \\
\hline
\end{tabular}

Summary of Results. I. Competition or rivalry of the vision-fields is never prominent. In some cases, on first opening the eyes there was a slight struggle of the impressions, but this soon ceased, and after a few moments the competition was no longer observable. The observer was frequently unable to distinguish between the colours of the two glasses, even when attending exclusively to this point.

2. The result of the mixture of the two impressions was not usually, as with the former method of binocular mixture, to produce a colour midway between the two that were combined. Sometimes the total impression would be quite near [224] 
to the quality of one or other of the monocular colours, but even when it was quite unlike either of them the result was not always that produced by other methods of mixing.

3. The colour quality of the impression was usually very vague. Coloured objects in the field of vision were noticed to have a different appearance from that remembered, but the attempt to tell what was the colour of the glasses before the eyes was seldom successful. Often it was only concerning one side that the observer could give a decided opinion. Seldom did his judgment correspond to the objective facts. Sometimes he would be right as to one of the colours, but wrong as to the other. And even when approximately correct as to the colours of both glasses, he would often be mistaken regarding the eyes before which the respective colours were presented.

4. The rather frequent appearance of a lustre effect is noteworthy. This phenomenon appeared only upon red or orange-coloured surfaces (except once or twice with purple) of small area. It was mostly upon the small coloured discs on the card that it was noticed. It was, however, quite plainly seen upon the very small, bright red leaves of ivy, growing round a stone chimney just outside the window.

III. STEREOSCOPIC LUSTRE FROM DIFFERENCE OF INTENSITY AND OF COLOUR BETWEEN THE RETINAL IMAGES.

In the previous article, dealing with the intensity relations of stereoscopic vision ${ }^{1}$ there were described some experiments upon the production of lustre by differences of brightness between the images in the two eyes. A further problem in that connection was suggested by the results of the experiments in binocular mixture of colours, reported in a preceding section of the present article. As mentioned there, there occurred quite frequently a lustre effect, which, upon closer examination, appeared to be due to differences of intensity so slight as to have otherwise passed unnoticed. In the

1 University of Toronto Studies, Psych. Series, Vol, ii, No. 2.

[225] 
experiments upon stereoscopic lustre with uncoloured light, such very slight differences of brightness had not been found to produce the phenomenon, so that it seemed probable that the effect would appear with smaller differences of brightness where there is also a decided difference of colour. This question was investigated by a method similar to that employed in the experiments with white light, the only difference being that on the rear wall of the apparatus, in place of the squares of white paper and black velvet respectively, there were placed squares of differently coloured paper. The objects were, as before, etchings on plate glass (Fig. 4). The two pairs used both formed truncated pyramids with the apices toward the observer. Seven colours were used, chiefly of the Milton-Bradley series, viz., red, orange, yellow, green, blue, violet, and purple. These were illuminated by an 8 c.p. incandescent electric lamp on eachside of the apparatus. The colours obtained by this arrange-ment were of course by no means spectrally pure, but thay possessed the additional interest of being more like the colours commonly seen. The spectra reflected by the papers under the prevailing conditions of illumination, and their comparative intensities, were as follows :-

\begin{tabular}{|c|c|c|}
\hline Name of Colour. & $\begin{array}{l}\text { Comparative } \\
\text { Intensity. }\end{array}$ & Portion of Spectrum Visible in $\mu \mu$ \\
\hline Red....... & 360 & $680-480 \quad(640)$ \\
\hline Orange...... & 360 & $670-550(590-600)$ \\
\hline Yellow...... & 310 & $670-500(570)$ \\
\hline Green....... & 320 & $650-500(530-540)$ \\
\hline Blue........ & I 25 & Whole spectrum dimly visible $(500)$ \\
\hline Violet. . . . . . & I 80 & $\begin{array}{l}\text { Whole spectrum visible-yellow and yel- } \\
\text { low-green very weak. }\end{array}$ \\
\hline Purple....... & I8o & $\begin{array}{l}\text { Whole spectrum visible-yellow and } \\
\text { green weak. }\end{array}$ \\
\hline
\end{tabular}

One colour being placed opposite the inner lens of the stereoscope, i.e., the one before which the episkotister disc revolved, and a different one opposite the other lens, the disc was then adjusted to admit only a single degree of light, and the amount gradually increased to the largest amount that 
the disc was capable of admitting, viz. $320^{\circ}$, at which point no difference could be noticed between the effect and that of the full light. Then the colour on the unobscured side was replaced by another, and so on until all of the other six colours had been combined with the partially obscured one. Then another colour was placed behind the disc, and each of the others combined with it, as before. By this means each of the seven colours, in all degrees of brightness, was combined with each of the others. The results are summarized in Tables XXXII to XLV, which show also the amounts of light which had to be admitted through the disc for the production of any, and of complete stereoscopic combination. With regard to lustre also, the figures indicate the smallest opening of the disc with which it appears at all, and the least opening with which it is complete. Wherever the lustre was reported as "decided" or "perfect" it continued so, as the opening of the disc widened, even up to $360^{\circ}$. The colour named in the heading of the table is in each case the colour before which the episkotister was rotated; the colours indicated in the first column of the tables are those combined with it.

Two series were also made in the same way, combining white with coloured light. In one of these the white was behind the episkotister, and the colour remained constant in intensity, in the other the white was constant and the colours behind the disc. The results are shown in Tables XIVI-XLVII. 
Table XXXII.-Red. Observer, W.A.M.

\begin{tabular}{|c|c|c|c|c|}
\hline $\begin{array}{l}\text { Compared } \\
\text { Colour. }\end{array}$ & $\begin{array}{l}\text { Opening of the } \\
\text { Episkotister } \\
\text { Disc. }\end{array}$ & $\begin{array}{c}\text { Ratio of the in- } \\
\text { tensities of the } \\
\text { objects presented } \\
\text { to the respective } \\
\text { Eyes. }\end{array}$ & Lustre. & Stereoscopic Effect. \\
\hline Orange. & $\begin{array}{l}10^{\circ} \\
20^{\circ} \\
40^{\circ} \\
60^{\circ}\end{array}$ & $\begin{array}{r}36.00 \\
18.00 \\
9.00 \\
6.00\end{array}$ & $\begin{array}{l}\text { None. } \\
\text { Slight. } \\
\text { Brighter. } \\
\text { Good. }\end{array}$ & $\begin{array}{l}\text { Partial. } \\
\text { Do. } \\
\text { Good. } \\
\text { Do. }\end{array}$ \\
\hline Yellow. & $\begin{array}{r}30^{\circ} \\
60^{\circ} \\
100^{\circ}\end{array}$ & $\begin{array}{r}10.33 \\
5.16 \\
3.10\end{array}$ & $\begin{array}{l}\text { None. } \\
\text { Slight. } \\
\text { Decided. }\end{array}$ & $\begin{array}{l}\text { Imperfect. } \\
\text { Good. } \\
\text { Do. }\end{array}$ \\
\hline Green. & $\begin{array}{r}8^{\circ} \\
10^{\circ} \\
60^{\circ} \\
100^{\circ}\end{array}$ & $\begin{array}{r}40.00 \\
32.00 \\
5.33 \\
3.20\end{array}$ & $\begin{array}{l}\text { None. } \\
\text { None. } \\
\text { Slight. } \\
\text { Perfect }\end{array}$ & $\begin{array}{l}\text { Partial. } \\
\text { Complete. } \\
\text { Do. } \\
\text { Do. }\end{array}$ \\
\hline Blue. & $\begin{array}{l}10^{\circ} \\
20^{\circ}\end{array}$ & $\begin{array}{r}12.50 \\
6.25\end{array}$ & $\left\{\begin{array}{l}\text { None } \\
\text { occurs. }\end{array}\right.$ & $\begin{array}{l}\text { Partial. } \\
\text { Good. }\end{array}$ \\
\hline Violet & $\begin{array}{l}10^{\circ} \\
30^{\circ}\end{array}$ & $\begin{array}{r}18.00 \\
6.00\end{array}$ & \} $\begin{array}{l}\text { None } \\
\text { occurs. }\end{array}$ & $\begin{array}{l}\text { Partial } \\
\text { Good. }\end{array}$ \\
\hline Purple & $\begin{array}{l}10^{\circ} \\
40^{\circ}\end{array}$ & $\begin{array}{r}18.00 \\
4.50\end{array}$ & \} $\begin{array}{l}\text { None. } \\
\text { occurs. }\end{array}$ & $\begin{array}{l}\text { Partial. } \\
\text { Good. }\end{array}$ \\
\hline
\end{tabular}


Table XXXili.-Orange. Observer, W.A.M.

\begin{tabular}{|c|c|c|c|c|}
\hline $\begin{array}{c}\text { Compared } \\
\text { Colour. }\end{array}$ & $\begin{array}{l}\text { Opening of the } \\
\text { Episkotister } \\
\text { Disc. }\end{array}$ & $\begin{array}{c}\text { Ratio of the in- } \\
\text { tensities of the } \\
\text { objects presented } \\
\text { to the respective } \\
\text { Eyes. }\end{array}$ & Lustre. & Stereoscopic Effect. \\
\hline Red. & $\begin{array}{r}6^{\circ} \\
12^{\circ} \\
40^{\circ} \\
160^{\circ}\end{array}$ & $\begin{array}{r}60.00 \\
30.00 \\
9.00 \\
2.25\end{array}$ & $\begin{array}{l}\text { None. } \\
\text { Do. } \\
\text { Slight. } \\
\text { Distinct. }\end{array}$ & $\begin{array}{l}\text { Poor. } \\
\text { Distinct. } \\
\text { Do. } \\
\text { Do. }\end{array}$ \\
\hline Yellow. & $\begin{array}{r}8^{\circ} \\
20^{\circ}\end{array}$ & $\begin{array}{l}38.75 \\
\text { I } 5 \cdot 50 \\
\end{array}$ & $\left\{\begin{array}{l}\text { None } \\
\text { occurs. }\end{array}\right.$ & $\begin{array}{l}\text { With effort. } \\
\text { Good. }\end{array}$ \\
\hline Green. & $\begin{array}{l}10^{\circ} \\
20^{\circ}\end{array}$ & $\begin{array}{l}32.00 \\
16.00\end{array}$ & $\left\{\begin{array}{l}\text { None } \\
\text { occurs. }\end{array}\right.$ & $\begin{array}{l}\text { With effort. } \\
\text { With ease. }\end{array}$ \\
\hline Blue. & $\begin{array}{l}8^{\circ} \\
50^{\circ} \\
60^{\circ} \\
90^{\circ}\end{array}$ & $\begin{array}{r}\text { I } 5.62 \\
2.50 \\
2.08 \\
I .38\end{array}$ & $\begin{array}{l}\text { None. } \\
\text { Do. } \\
\text { Slight. } \\
\text { Decided. }\end{array}$ & $\begin{array}{l}\text { Partial. } \\
\text { Good. } \\
\text { Do. } \\
\text { Do. }\end{array}$ \\
\hline Violet & $\begin{array}{r}10^{\circ} \\
30^{\circ} \\
70^{\circ} \\
120^{\circ}\end{array}$ & $\begin{array}{r}\text { I } 8.00 \\
6.00 \\
2.57 \\
1.50\end{array}$ & $\begin{array}{l}\text { None. } \\
\text { Do. } \\
\text { Faint. } \\
\text { Uncertain. }\end{array}$ & $\begin{array}{l}\text { Poor. } \\
\text { Good. } \\
\text { Do. } \\
\text { Do. }\end{array}$ \\
\hline Purple. & $\begin{array}{r}10^{\circ} \\
30^{\circ} \\
70^{\circ} \\
100^{\circ}\end{array}$ & $\begin{array}{r}\text { I } 8.00 \\
6.00 \\
2.57 \\
1.80\end{array}$ & $\begin{array}{l}\text { None. } \\
\text { Do. } \\
\text { Slight. } \\
\text { Decided. }\end{array}$ & $\begin{array}{l}\text { Partial. } \\
\text { Complete } \\
\text { Do. } \\
\text { Do. }\end{array}$ \\
\hline
\end{tabular}


Table XXXIV.-Yellow. Observer, W.A.M.

\begin{tabular}{|c|c|c|c|c|}
\hline $\begin{array}{l}\text { Compared } \\
\text { Colour. }\end{array}$ & $\begin{array}{l}\text { Opening of the } \\
\text { Episkotister } \\
\text { Disc. }\end{array}$ & $\begin{array}{l}\text { Ratio of the in- } \\
\text { tensities of the } \\
\text { objects presented } \\
\text { to the respective } \\
\text { Eyes. }\end{array}$ & Lustre. & Stereoscopic Effect. \\
\hline Red. & $\begin{array}{l}10^{\circ} \\
15^{\circ} \\
30^{\circ} \\
40^{\circ}\end{array}$ & $\begin{array}{l}41.80 \\
24.64 \\
\text { r } 3.93 \\
\text { ro.45 }\end{array}$ & $\begin{array}{l}\text { None. } \\
\text { Slight. } \\
\text { Better. } \\
\text { Good. }\end{array}$ & $\begin{array}{l}\text { Partial. } \\
\text { Do. } \\
\text { Good. } \\
\text { Do. }\end{array}$ \\
\hline Orange. & $\begin{array}{l}10^{\circ} \\
30^{\circ}\end{array}$ & $\begin{array}{l}41.80 \\
13.93\end{array}$ & $\left\{\begin{array}{l}\text { None } \\
\text { occurs. }\end{array}\right.$ & $\begin{array}{l}\text { Partial. } \\
\text { Good. }\end{array}$ \\
\hline Green. & $\begin{array}{l}10^{\circ} \\
30^{\circ}\end{array}$ & $\begin{array}{l}37 \cdot 16 \\
\times 2 \cdot 38\end{array}$ & $\begin{array}{l}\text { Slight. } \\
\text { Good. }\end{array}$ & $\begin{array}{l}\text { None. } \\
\text { Partial. } \\
\text { (Never becomes } \\
\quad \text { perfect) }\end{array}$ \\
\hline Blue. & $\begin{array}{r}6^{\circ} \\
15^{\circ} \\
60^{\circ} \\
90^{\circ}\end{array}$ & $\begin{array}{r}24.19 \\
9.67 \\
2.41 \\
1.61\end{array}$ & $\begin{array}{l}\text { None. } \\
\text { Do. } \\
\text { Slight. } \\
\text { Decided. }\end{array}$ & $\begin{array}{l}\text { Poor. } \\
\text { Good. } \\
\text { Do. } \\
\text { Do. }\end{array}$ \\
\hline Violet & $\begin{array}{r}8^{\circ} \\
\mathrm{I} 5^{\circ}\end{array}$ & $\begin{array}{l}25.80 \\
13.93\end{array}$ & $\left\{\begin{array}{l}\text { None } \\
\text { occurs. }\end{array}\right.$ & $\begin{array}{l}\text { Partial. } \\
\text { Good. }\end{array}$ \\
\hline Purple & $\begin{array}{r}6^{\circ} \\
15^{\circ} \\
70^{\circ} \\
90^{\circ}\end{array}$ & $\begin{array}{r}34.83 \\
\times 3.93 \\
3.15 \\
2.03\end{array}$ & $\begin{array}{l}\text { None. } \\
\text { Do. } \\
\text { Slight. } \\
\text { Good. }\end{array}$ & $\begin{array}{l}\text { Partial. } \\
\text { Do. } \\
\text { Perfect. } \\
\text { Do. }\end{array}$ \\
\hline
\end{tabular}


Table XXXV.-Green. Observer, W.A.M.

\begin{tabular}{|c|c|c|c|c|}
\hline $\begin{array}{l}\text { Compared } \\
\text { Colour. }\end{array}$ & $\begin{array}{l}\text { Opening of the } \\
\text { Episkotister } \\
\text { Dise. }\end{array}$ & $\begin{array}{c}\text { Ratio of the in- } \\
\text { tensities of the } \\
\text { objects presented } \\
\text { to the respective } \\
\text { Eyes. }\end{array}$ & Lustre. & Stereoseopic Effect. \\
\hline Red. & $\begin{array}{r}10^{\circ} \\
20^{\circ} \\
60^{\circ} \\
100^{\circ}\end{array}$ & $\begin{array}{r}39.75 \\
19.87 \\
6.65 \\
3.97\end{array}$ & $\begin{array}{l}\text { None. } \\
\text { Do. } \\
\text { Slight. } \\
\text { Perfect. }\end{array}$ & $\begin{array}{l}\text { Partial. } \\
\text { Complete. } \\
\text { Do. } \\
\text { Do. }\end{array}$ \\
\hline Orange. & $\begin{array}{r}10^{\circ} \\
40^{\circ} \\
60^{\circ} \\
160^{\circ}\end{array}$ & $\begin{array}{r}39.75 \\
9.95 \\
6.65 \\
2.49\end{array}$ & $\begin{array}{l}\text { None. } \\
\text { Do. } \\
\text { Little. } \\
\text { None. }\end{array}$ & $\begin{array}{l}\text { Inconstant. } \\
\text { Perfect. } \\
\text { Do. } \\
\text { Do. }\end{array}$ \\
\hline Yellow. & $\begin{array}{r}8^{\circ} \\
15^{\circ}\end{array}$ & $\begin{array}{l}43.60 \\
23.25\end{array}$ & \} $\begin{array}{l}\text { No decided } \\
\text { lustreappears }\end{array}$ & $\begin{array}{l}\text { Partial. } \\
\text { Good. }\end{array}$ \\
\hline Blue. & $8^{\circ}$ & $17 \cdot 57$ & $\left\{\begin{array}{l}\text { None } \\
\text { appears. }\end{array}\right.$ & $\begin{array}{l}\text { Complete effect } \\
\text { appears at once }\end{array}$ \\
\hline Violet. & $\begin{array}{r}8^{\circ} \\
20^{\circ}\end{array}$ & $\begin{array}{l}25.31 \\
10.12\end{array}$ & $\begin{array}{l}\text { No appear- } \\
\text { ance of lustre } \\
\text { at all. }\end{array}$ & $\begin{array}{l}\text { Imperfect. } \\
\text { Complete. }\end{array}$ \\
\hline Purple. & $\begin{array}{l}15^{\circ} \\
40^{\circ}\end{array}$ & $\begin{array}{r}13.50 \\
5.06\end{array}$ & \} $\begin{array}{l}\text { None } \\
\text { appears. }\end{array}$ & $\begin{array}{l}\text { With effort. } \\
\text { With ease. }\end{array}$ \\
\hline
\end{tabular}


Table XXXVi.-Blue. Observer, W.A.M.

\begin{tabular}{|c|c|c|c|c|}
\hline $\begin{array}{l}\text { Compared } \\
\text { Colour. }\end{array}$ & $\begin{array}{l}\text { Opening of the } \\
\text { Episkotister } \\
\text { Disc. }\end{array}$ & $\begin{array}{c}\text { Ratio of the in- } \\
\text { tensities of the } \\
\text { objects presented } \\
\text { to the respective } \\
\text { Eyes. }\end{array}$ & Lustre & Stereoscopic Effect \\
\hline Red. & $\begin{array}{l}15^{\circ} \\
50^{\circ} \\
80^{\circ} \\
90^{\circ}\end{array}$ & $\begin{array}{l}70.72 \\
20.73 \\
12.96 \\
11.5^{2}\end{array}$ & $\begin{array}{l}\text { None. } \\
\text { Do. } \\
\text { Little. } \\
\text { None. }\end{array}$ & $\begin{array}{l}\text { Poor. } \\
\text { Partial. } \\
\text { With effort. } \\
\text { Perfect. }\end{array}$ \\
\hline Orange. & $\begin{array}{r}20^{\circ} \\
60^{\circ} \\
90^{\circ} \\
220^{\circ}\end{array}$ & $\begin{array}{r}51.84 \\
17.28 \\
\text { II. } 52 \\
4.79\end{array}$ & $\begin{array}{l}\text { None. } \\
\text { Little. } \\
\text { Better. } \\
\text { Very good. }\end{array}$ & $\begin{array}{l}\text { Partial. } \\
\text { Complete. } \\
\text { Do. } \\
\text { Do. }\end{array}$ \\
\hline Yellow & $\begin{array}{r}6^{\circ} \\
10^{\circ} \\
40^{\circ}\end{array}$ & $\begin{array}{r}\mathrm{I} 48.80 \\
89.28 \\
22.32\end{array}$ & $\begin{array}{l}\text { None. } \\
\text { Do. } \\
\text { Slight. } \\
\text { (Never be- } \\
\text { comes good.) }\end{array}$ & $\begin{array}{l}\text { Partial. } \\
\text { Complete } \\
\text { Do. }\end{array}$ \\
\hline Green. & $\begin{array}{r}15^{\circ} \\
60^{\circ} \\
\mathrm{r} 40^{\circ}\end{array}$ & $\begin{array}{r}6 \mathrm{I} .48 \\
\text { I } 5.36 \\
6.58\end{array}$ & $\begin{array}{l}\text { None. } \\
\text { Little. } \\
\text { None. }\end{array}$ & $\begin{array}{l}\text { With effort. } \\
\text { (Never com- } \\
\text { bine perfectly.) }\end{array}$ \\
\hline Violet. & $\begin{array}{r}6^{\circ} \\
15^{\circ}\end{array}$ & $\begin{array}{l}86.40 \\
34 \cdot 5^{6} \\
\end{array}$ & $\left\{\begin{array}{l}\text { None } \\
\text { appears. }\end{array}\right.$ & $\begin{array}{l}\text { Difficult. } \\
\text { Perfect. }\end{array}$ \\
\hline Purple. & $60^{\circ}$ & 8.64 & None. & $\begin{array}{l}\text { With effort, and } \\
\text { so throughout. }\end{array}$ \\
\hline
\end{tabular}


Table XXXViI.-Violet. Observer, W.A.M.

\begin{tabular}{|c|c|c|c|c|}
\hline $\begin{array}{l}\text { Compared } \\
\text { Colour. }\end{array}$ & $\begin{array}{l}\text { Opening of the } \\
\text { Episkotister } \\
\text { Disc. }\end{array}$ & $\begin{array}{l}\text { Ratio of the in- } \\
\text { tensities of the } \\
\text { objects presented } \\
\text { to the respective } \\
\text { Eyes. }\end{array}$ & Lustre. & Stercoscopic Effect. \\
\hline Red. & $\begin{array}{r}70^{\circ} \\
140^{\circ}\end{array}$ & $\begin{array}{r}10.28 \\
5.14\end{array}$ & \} None. & $\begin{array}{l}\text { Partial. } \\
\text { Complete. }\end{array}$ \\
\hline Orange. & $\begin{array}{l}20^{\circ} \\
70^{\circ}\end{array}$ & $\begin{array}{l}36.00 \\
10.28\end{array}$ & \} None. & $\begin{array}{l}\text { Partial. } \\
\text { Complete. }\end{array}$ \\
\hline Yellow. & $\begin{array}{l}40^{\circ} \\
60^{\circ}\end{array}$ & $\begin{array}{l}\text { I5. } 50 \\
10.36\end{array}$ & \} None. & $\begin{array}{l}\text { Partial. } \\
\text { Complete. }\end{array}$ \\
\hline Green. & $\begin{array}{l}20^{\circ} \\
30^{\circ}\end{array}$ & $\begin{array}{l}32.00 \\
2 \mathrm{I} .33\end{array}$ & \} None. & $\begin{array}{l}\text { Partial. } \\
\text { Complete. }\end{array}$ \\
\hline Blue. & $\begin{array}{l}30^{\circ} \\
80^{\circ}\end{array}$ & $\begin{array}{l}8.33 \\
3.12\end{array}$ & \} None. & $\begin{array}{l}\text { Partial. } \\
\text { Complete. }\end{array}$ \\
\hline Purple. & $\begin{array}{l}15^{\circ} \\
40^{\circ} \\
90^{\circ}\end{array}$ & $\begin{array}{r}24.00 \\
9.00 \\
4.00\end{array}$ & $\begin{array}{l}\text { None. } \\
\text { Slight. } \\
\text { Very fair. }\end{array}$ & $\begin{array}{l}\text { Partial. } \\
\text { Better. } \\
\text { Complete. }\end{array}$ \\
\hline
\end{tabular}

Table XXXVIII.-PUrple. Observer, W.A.M.

\begin{tabular}{|c|c|c|c|c|}
\hline Compared & $\begin{array}{l}\text { Opening of the } \\
\text { Episkotister } \\
\text { Disc. }\end{array}$ & \begin{tabular}{|l|} 
Ratio of the in- \\
tensities of the \\
objects presented \\
to the respective \\
Eyes.
\end{tabular} & Lustre. & Stereoscopic Effect. \\
\hline Red. & $\begin{array}{l}20^{\circ} \\
90^{\circ}\end{array}$ & $\begin{array}{r}36.00 \\
8.00\end{array}$ & None. & $\begin{array}{l}\text { Partial. } \\
\text { Good. }\end{array}$ \\
\hline Orange. & $\begin{array}{l}20^{\circ} \\
60^{\circ} \\
90^{\circ}\end{array}$ & $\begin{array}{r}36.00 \\
12.00 \\
8.00\end{array}$ & $\begin{array}{l}\text { None. } \\
\text { Slight. } \\
\text { Decided. }\end{array}$ & $\begin{array}{l}\text { Imperfect. } \\
\text { Complete. } \\
\text { Do. }\end{array}$ \\
\hline Yellow. & $\begin{array}{r}30^{\circ} \\
70^{\circ} \\
100^{\circ}\end{array}$ & $\begin{array}{r}20.66 \\
8.85 \\
6.20\end{array}$ & $\begin{array}{l}\text { None. } \\
\text { None. } \\
\text { Slight. (Never } \\
\text { becomes good. }\end{array}$ & $\begin{array}{l}\text { Partial. } \\
\text { Good. } \\
\text { Do. }\end{array}$ \\
\hline Green. & $\begin{array}{r}80^{\circ} \\
120^{\circ}\end{array}$ & $\begin{array}{l}8.00 \\
5.33\end{array}$ & None. & $\begin{array}{l}\text { Partial. } \\
\text { Perfect. }\end{array}$ \\
\hline Blue. & $60^{\circ}$ & $4 \cdot 16$ & None. & $\begin{array}{l}\text { At once } \\
\text { complete. }\end{array}$ \\
\hline Violet. & $\begin{array}{l}10^{\circ} \\
20^{\circ} \\
30^{\circ} \\
60^{\circ}\end{array}$ & $\begin{array}{r}36.00 \\
18.00 \\
\text { I } 2.00 \\
6.00\end{array}$ & $\begin{array}{l}\text { None. } \\
\text { Slight. } \\
\text { Do. } \\
\text { Good. }\end{array}$ & $\begin{array}{l}\text { Partial. } \\
\text { Do. } \\
\text { Good. } \\
\text { Do. }\end{array}$ \\
\hline
\end{tabular}


TAble XXXIX.-Red. Observbr, P.B.T.

\begin{tabular}{|c|c|c|c|c|}
\hline $\begin{array}{l}\text { Compared } \\
\text { Colour. }\end{array}$ & $\begin{array}{l}\text { Opening of the } \\
\text { Episkotister } \\
\text { Disc. }\end{array}$ & $\begin{array}{c}\text { Ratio of the in- } \\
\text { tensities of the } \\
\text { objects presented } \\
\text { to the respective } \\
\text { Eyes. }\end{array}$ & Lustre. & Stereoscopic Effect. \\
\hline Orange. & $\begin{array}{r}10^{\circ} \\
12 \frac{1}{2}^{\circ} \\
30^{\circ}\end{array}$ & $\begin{array}{l}36.00 \\
29.60 \\
12.00\end{array}$ & $\begin{array}{l}\text { None. } \\
\text { Slight. } \\
\text { Good. }\end{array}$ & $\begin{array}{l}\text { Partial. } \\
\text { Do. } \\
\text { Complete. }\end{array}$ \\
\hline Yellow. & $\begin{array}{l}10^{\circ} \\
20^{\circ} \\
50^{\circ}\end{array}$ & $\begin{array}{r}31.00 \\
15.50 \\
6.20\end{array}$ & $\begin{array}{l}\text { None. } \\
\text { Slight. } \\
\text { Good. }\end{array}$ & $\begin{array}{l}\text { Complete. } \\
\text { Do. } \\
\text { Do. }\end{array}$ \\
\hline Green. & $\begin{array}{l}12^{\circ} \\
20^{\circ} \\
80^{\circ}\end{array}$ & $\begin{array}{r}26.66 \\
16.00 \\
4.00\end{array}$ & $\begin{array}{l}\text { None. } \\
\text { Do. } \\
\text { Partial. }\end{array}$ & $\begin{array}{l}\text { Slight. } \\
\text { Good. } \\
\text { Do. }\end{array}$ \\
\hline Blue. & $\begin{array}{l}10^{\circ} \\
23^{\circ}\end{array}$ & $\begin{array}{r}\text { I } 2.50 \\
5.43\end{array}$ & $\begin{array}{c}\text { None. } \\
\text { Do. }\end{array}$ & $\begin{array}{l}\text { Partial. } \\
\text { Complete. }\end{array}$ \\
\hline $\begin{array}{l}\text { Violet. } \\
\text { : }\end{array}$ & $\begin{array}{r}6^{\circ} \\
17 \frac{1}{2}^{\circ} \\
30^{\circ}\end{array}$ & $\begin{array}{r}30.00 \\
10.28 \\
6.00\end{array}$ & $\begin{array}{l}\text { None. } \\
\text { Do. } \\
\text { Good. }\end{array}$ & $\begin{array}{c}\text { Partial. } \\
\text { Complete. } \\
\text { Do. }\end{array}$ \\
\hline Purple. & $\begin{array}{r}15^{\circ} \\
-30^{\circ}\end{array}$ & $\begin{array}{r}\text { I } 2.00 \\
6.00\end{array}$ & $\begin{array}{l}\text { None. } \\
\text { Do.: }\end{array}$ & $\begin{array}{l}\text { Partial. } \\
\text { Complete. }\end{array}$ \\
\hline
\end{tabular}


Table Xl.-Orange, Observer, P.B.T.

\begin{tabular}{|c|c|c|c|c|}
\hline $\begin{array}{l}\text { Compared } \\
\text { Calour. }\end{array}$ & $\begin{array}{c}\text { Opening of the } \\
\text { Episkotister } \\
\text { Disc. }\end{array}$ & \begin{tabular}{|c|} 
Ratio of the in- \\
tensities of the \\
objects presented \\
to the respective \\
Eyes.
\end{tabular} & Lustre. & Stereoscopic Effect. \\
\hline Red. & $\begin{array}{r}6^{\circ} \\
150^{\circ}\end{array}$ & $\begin{array}{r}60.00 \\
2.40\end{array}$ & $\begin{array}{l}\text { None. } \\
\text { *Traces. }\end{array}$ & $\begin{array}{c}\text { Complete. } \\
\text { Dc. }\end{array}$ \\
\hline Yellow. & $\begin{array}{l}10^{\circ} \\
20^{\circ}\end{array}$ & $\begin{array}{l}31.00 \\
16.50\end{array}$ & $\begin{array}{c}\text { None. } \\
\text { Do. }\end{array}$ & $\begin{array}{l}\text { Partial. } \\
\text { Complete. }\end{array}$ \\
\hline Green. & $\begin{array}{l}10^{\circ} \\
60^{\circ}\end{array}$ & $\begin{array}{r}32.00 \\
5.33\end{array}$ & $\begin{array}{l}\text { None. } \\
\text { Same, never } \\
\text { becomes good. }\end{array}$ & $\begin{array}{l}\text { Complete. } \\
\text { Do. }\end{array}$ \\
\hline Blue. & $\begin{array}{l}6^{\circ} \\
12^{\circ} \\
20^{\circ}\end{array}$ & $\begin{array}{r}20.83 \\
10.41 \\
6.25\end{array}$ & $\begin{array}{l}\text { None. } \\
\text { Fair. } \\
\text { Good. }\end{array}$ & $\begin{array}{c}\text { Complete. } \\
\text { Do. } \\
\text { Do. }\end{array}$ \\
\hline Violet. & $\begin{array}{r}12^{\circ} \\
200^{\circ}\end{array}$ & $\begin{array}{r}\text { I } 5.00 \\
\text { I. I I }\end{array}$ & $\begin{array}{l}\text { None. } \\
\text { *Slight traces. }\end{array}$ & $\begin{array}{l}\text { Complete. } \\
\text { Do }\end{array}$ \\
\hline Purple. & $\begin{array}{l}6^{\circ} \\
15^{\circ} \\
50^{\circ} \\
60^{\circ}\end{array}$ & $\begin{array}{r}30.00 \\
12.00 \\
3.60 \\
3.00\end{array}$ & $\begin{array}{l}\text { None. } \\
\text { Do. } \\
\text { Do. } \\
\text { Slight. }\end{array}$ & $\begin{array}{l}\text { Slight. } \\
\text { Fair. } \\
\text { Good. }\end{array}$ \\
\hline
\end{tabular}

* Hard to distinguish lustre from brightness of the object.

** Increases with greater intensity of Orange, but never becomes very decided. 
ROBINSON : STEREOSCOPIC VISION

Table Xli.-Yellow. Observer, P.B.T.

\begin{tabular}{|c|c|c|c|c|}
\hline $\begin{array}{l}\text { Compared } \\
\text { Colour. }\end{array}$ & $\begin{array}{l}\text { Opening of the } \\
\text { Episkotister } \\
\text { Disc. }\end{array}$ & $\begin{array}{c}\text { Ratio of the in- } \\
\text { tensities of the } \\
\text { objects presented } \\
\text { to the respective } \\
\text { Eyes. }\end{array}$ & Lustre. & Stereoscopic Effect. \\
\hline Red. & $\begin{array}{r}8^{\circ} \\
40^{\circ} \\
100^{\circ}\end{array}$ & $\begin{array}{r}52.25 \\
10.45 \\
4.18\end{array}$ & $\begin{array}{l}\text { Slight. } \\
\text { Good. } \\
\text { Very good. }\end{array}$ & $\begin{array}{l}\text { Slight. } \\
\text { Complete. } \\
\text { Do. }\end{array}$ \\
\hline Orange. & $\begin{array}{r}6^{\circ} \\
15^{\circ}\end{array}$ & $\begin{array}{l}69.67 \\
27.87\end{array}$ & $\begin{array}{l}\text { None. } \\
\text { Do. }\end{array}$ & $\begin{array}{l}\text { Partial. } \\
\text { Complete. }\end{array}$ \\
\hline Green. & I $2 \frac{1}{2}^{\circ}$ & $29 \cdot 72$ & None. & Complete. \\
\hline Blue. & $\begin{array}{r}6^{\circ} \\
10^{\circ}\end{array}$ & $\begin{array}{l}24.19 \\
14 \cdot 5 \text { I }\end{array}$ & $\begin{array}{l}\text { None. } \\
\text { *Slight. }\end{array}$ & $\begin{array}{l}\text { Imperfect. } \\
\text { Complete. }\end{array}$ \\
\hline Violet. & $\begin{array}{r}6^{\circ} \\
10^{\circ} \\
130^{\circ}\end{array}$ & $\begin{array}{r}34.83 \\
20.25 \\
\mathrm{I} .55\end{array}$ & $\begin{array}{l}\text { None. } \\
\text { Do. } \\
\text { Extremely } \\
\text { Slight. }\end{array}$ & $\begin{array}{l}\text { Partial. } \\
\text { Complete. } \\
\text { Do. }\end{array}$ \\
\hline Purple. & $\begin{array}{r}8^{\circ} \\
30^{\circ} \\
50^{\circ}\end{array}$ & $\begin{array}{r}25.48 \\
6.96 \\
4.18\end{array}$ & $\begin{array}{l}\text { None. } \\
\text { Do. } \\
\text { Slight. }\end{array}$ & $\begin{array}{l}\text { Partial. } \\
\text { Good. } \\
\text { Do. }\end{array}$ \\
\hline
\end{tabular}

* Above $10^{\circ}$ there was lustre-sometimes more, sometimes less decided-but never perfect.

Table XliI.-Green. Observer, P.B.T.

\begin{tabular}{|c|c|c|c|c|}
\hline $\begin{array}{l}\text { Compared } \\
\text { Colour. }\end{array}$ & $\begin{array}{l}\text { Opening of the } \\
\text { Episkotister } \\
\text { Disc. }\end{array}$ & $\mid \begin{array}{c}\text { Ratio of the in- } \\
\text { tensities of the } \\
\text { objects presented } \\
\text { to the respective } \\
\text { Eyes. }\end{array}$ & Lustre. & Stereoscopic Effect. \\
\hline Red. & $\begin{array}{r}8^{\circ} \\
\mathrm{I} 2^{\circ} \\
\mathrm{I} 60^{\circ}\end{array}$ & $\begin{array}{r}50.62 \\
33.74 \\
2.53\end{array}$ & $\begin{array}{l}\text { None. } \\
\text { Do. } \\
\text { Very slight. }\end{array}$ & $\begin{array}{l}\text { Partial. } \\
\text { Complete. } \\
\text { Do. }\end{array}$ \\
\hline Orange. & $\begin{array}{l}12^{\circ} \\
40^{\circ}\end{array}$ & $\begin{array}{l}33.75 \\
10.12\end{array}$ & $\begin{array}{l}\text { None. } \\
\text { Do. }\end{array}$ & $\begin{array}{l}\text { Partial. } \\
\text { Complete. }\end{array}$ \\
\hline Yellow. & $\begin{array}{l}15^{\circ} \\
40^{\circ}\end{array}$ & $\begin{array}{r}23.25 \\
8.72\end{array}$ & $\begin{array}{l}\text { None. } \\
\text { Do. }\end{array}$ & $\begin{array}{l}\text { Partial. } \\
\text { Complete. }\end{array}$ \\
\hline Blue. & $10^{\circ}$ & I 4.06 & None. & Complete. \\
\hline Violet. & $\begin{array}{l}10^{\circ} \\
15^{\circ}\end{array}$ & $\begin{array}{l}20.25 \\
13.50\end{array}$ & $\begin{array}{l}\text { None. } \\
\text { Do. }\end{array}$ & $\begin{array}{l}\text { Imperfect. } \\
\text { Complete. }\end{array}$ \\
\hline Purple. & $\begin{array}{l}\text { I } 2^{\circ} \\
20^{\circ} \\
60^{\circ}\end{array}$ & $\begin{array}{l}\text { I6.89 } \\
\text { I0.1 I } \\
3 \cdot 37\end{array}$ & $\begin{array}{l}\text { None. } \\
\text { Do. } \\
\text { Faint. }\end{array}$ & $\begin{array}{l}\text { Partial. } \\
\text { Complete. } \\
\text { Do. }\end{array}$ \\
\hline
\end{tabular}


Robinson : STEREOSCOPIC VISION

Table Xliti.-Blue. Observer, P.B.T.

\begin{tabular}{|c|c|c|c|c|}
\hline $\begin{array}{l}\text { Compared } \\
\text { Colour. }\end{array}$ & $\begin{array}{l}\text { Opening of the } \\
\text { Episkotister } \\
\text { Disc. }\end{array}$ & \begin{tabular}{|c|} 
Ratio of the in- \\
tensities of the \\
objects presented \\
to the respective \\
Eyes.
\end{tabular} & Lustre. & Stereoscopic Effect. \\
\hline Red. & $\begin{array}{r}8^{\circ} \\
30^{\circ}\end{array}$ & $\begin{array}{r}\times 29.60 \\
34.56\end{array}$ & $\begin{array}{l}\text { None. } \\
\text { Do. }\end{array}$ & $\begin{array}{l}\text { Partial. } \\
\text { Complete. }\end{array}$ \\
\hline Orange. & $\begin{array}{l}20^{\circ} \\
40^{\circ} \\
70^{\circ}\end{array}$ & $\begin{array}{l}51.84 \\
25.92 \\
\times 4.83\end{array}$ & $\begin{array}{l}\text { None. } \\
\text { Slight. } \\
\text { Good. }\end{array}$ & $\begin{array}{l}\text { Partial. } \\
\text { Complete. }\end{array}$ \\
\hline Yellow. & $\begin{array}{r}8^{\circ} \\
10^{\circ}\end{array}$ & $\begin{array}{r}\text { XII.60 } \\
89.28\end{array}$ & $\begin{array}{l}\text { None. } \\
\text { Slight, never } \\
\text { becomes good }\end{array}$ & $\begin{array}{l}\text { Partial. } \\
\text { Complete. }\end{array}$ \\
\hline Green. & $25^{\circ}$ & 36.80 & None. & *Complete. \\
\hline Violet. & $20^{\circ}$ & $\begin{array}{l}25.92 \\
10.36\end{array}$ & $\begin{array}{l}\text { None. } \\
\text { Do. }\end{array}$ & $\begin{array}{l}\text { *Partial. } \\
\text { Complete. }\end{array}$ \\
\hline Purple. & $\begin{array}{l}50^{\circ} \\
90^{\circ}\end{array}$ & $\begin{array}{r}\text { xo.36 } \\
5.76\end{array}$ & $\begin{array}{c}\text { None. } \\
\text { Do. }\end{array}$ & $\begin{array}{l}\text { *Slight. } \\
\text { Fair. }\end{array}$ \\
\hline
\end{tabular}

\#Blue very dark, lines not clearly visible with smaller openings.

Table XlilV.-Violet . Observer, P.B.T.

\begin{tabular}{|c|c|c|c|c|}
\hline $\begin{array}{l}\text { Compared } \\
\text { Colour. }\end{array}$ & $\begin{array}{l}\text { Opening of the } \\
\text { Episkotister } \\
\text { Disc. }\end{array}$ & $\begin{array}{c}\text { Ratio of the in- } \\
\text { tensities of the } \\
\text { objects presented } \\
\text { to the respective } \\
\text { Eyes. }\end{array}$ & Lustre. & Stereoscopic Effect. \\
\hline Red. & $\begin{array}{r}8^{\circ} \\
20^{\circ} \\
60^{\circ}\end{array}$ & $\begin{array}{l}90.00 \\
36.00 \\
\times 2.00\end{array}$ & $\begin{array}{l}\text { None. } \\
\text { Slight. }\end{array}$ & $\begin{array}{c}\text { Imperfect. } \\
\text { Complete. } \\
\text { Do. }\end{array}$ \\
\hline Orange. & $\begin{array}{c}20^{\circ} \\
60^{\circ} \\
100^{\circ}-160^{\circ}\end{array}$ & $\begin{array}{c}36.00 \\
12.00 \\
7.20-4.50\end{array}$ & $\begin{array}{l}\text { None. } \\
\text { Do. } \\
\text { *Faint. }\end{array}$ & $\begin{array}{l}\text { Imperfect. } \\
\text { Complete. } \\
\text { Do. }\end{array}$ \\
\hline Yellow. & $\begin{array}{r}8^{\circ} \\
20^{\circ} \\
60^{\circ} \\
190^{\circ}\end{array}$ & $\begin{array}{r}77.50 \\
31.00 \\
10.33 \\
3.55 \\
\end{array}$ & $\begin{array}{l}\text { None. } \\
\text { Do. } \\
\text { Faint. } \\
\text { Disappears. }\end{array}$ & $\begin{array}{l}\text { Partial. } \\
\text { Complete. } \\
\text { Do. } \\
\text { Do. }\end{array}$ \\
\hline Green. & $\begin{array}{l}10^{\circ} \\
20^{\circ}\end{array}$ & $\begin{array}{l}64.00 \\
3^{2} .00\end{array}$ & $\begin{array}{l}\text { None. } \\
\text { Do. }\end{array}$ & $\begin{array}{l}\text { Partial. } \\
\text { Complete. }\end{array}$ \\
\hline Blue. & $\begin{array}{l}15^{\circ} \\
80^{\circ}\end{array}$ & $\begin{array}{r}16.66 \\
3.12\end{array}$ & $\begin{array}{l}\text { None. } \\
\text { Very faint. }\end{array}$ & $\begin{array}{c}\text { Complete. } \\
\text { Do. }\end{array}$ \\
\hline Purple. & $\begin{array}{l}15^{\circ} \\
70^{\circ}\end{array}$ & $\begin{array}{r}24.00 \\
5.14\end{array}$ & $\begin{array}{l}\text { None. } \\
\text { Do. }\end{array}$ & $\begin{array}{l}\text { Fair. } \\
\text { Perfect. }\end{array}$ \\
\hline
\end{tabular}

${ }^{*}$ Gradually fades as opening increases beyond 160 degrees. 
Table XlV.-Purple. Observer, P.B.T.

\begin{tabular}{|c|c|c|c|c|}
\hline $\begin{array}{l}\text { Compared } \\
\text { Colour. }\end{array}$ & $\begin{array}{l}\text { Opening of the } \\
\text { Episkotister } \\
\text { Dise. }\end{array}$ & \begin{tabular}{|c|} 
Ratio of the in- \\
tensities of the \\
objects presented \\
to the respective \\
Eyes.
\end{tabular} & Lustre. & Stereoscopic Effect. \\
\hline Red. & $\begin{array}{l}12^{\circ} \\
70^{\circ}\end{array}$ & $\begin{array}{l}60.00 \\
10.28\end{array}$ & $\begin{array}{l}\text { None. } \\
\text { Do. }\end{array}$ & $\begin{array}{l}\text { Partial. } \\
\text { Complete. }\end{array}$ \\
\hline Orange. & $\begin{array}{l}15^{\circ} \\
20^{\circ} \\
60^{\circ}\end{array}$ & $\begin{array}{l}48.00 \\
36.00 \\
12.00\end{array}$ & $\begin{array}{l}\text { None. } \\
\text { Fair. } \\
\text { Do. }\end{array}$ & $\begin{array}{l}\text { Partial. } \\
\text { Do. } \\
\text { Complete. }\end{array}$ \\
\hline Yellow. & $\begin{array}{r}12^{\circ} \\
17 \frac{10}{2} \\
20^{\circ}\end{array}$ & $\begin{array}{l}52.00 \\
36.51 \\
31.00\end{array}$ & $\begin{array}{l}\text { None. } \\
\text { Slight. } \\
\text { Do. }\end{array}$ & $\begin{array}{l}\text { Imperfect. } \\
\text { Do. } \\
\text { Complete. }\end{array}$ \\
\hline Green. & $\begin{array}{l}12^{\circ} \\
20^{\circ} \\
50^{\circ}\end{array}$ & $\begin{array}{l}53.33 \\
32.00 \\
12.80\end{array}$ & $\begin{array}{l}\text { None. } \\
\text { Do. } \\
\text { Slight. }\end{array}$ & $\begin{array}{l}\text { Partial. } \\
\text { Complete. } \\
\text { Do. }\end{array}$ \\
\hline Blue. & $\begin{array}{r}20^{\circ} \\
120^{\circ}\end{array}$ & $\begin{array}{r}12.50 \\
2.08\end{array}$ & $\begin{array}{l}\text { None. } \\
\text { Do. }\end{array}$ & $\begin{array}{c}\text { Complete. } \\
\text { Do. }\end{array}$ \\
\hline Violet. & $\begin{array}{r}20^{\circ} \\
240^{\circ}\end{array}$ & $\begin{array}{r}18.00 \\
1.12\end{array}$ & $\begin{array}{l}\text { Faint. } \\
\text { Increases, } \\
\text { but still weak. }\end{array}$ & $\begin{array}{c}\text { Complete. } \\
\text { Do. }\end{array}$ \\
\hline
\end{tabular}


Table XlVI.-White. Observer, W.

(White changing in intensity, Colour constant.)

\begin{tabular}{|c|c|c|c|c|}
\hline $\begin{array}{l}\text { Compared } \\
\text { Colour. }\end{array}$ & $\begin{array}{l}\text { Opening of the } \\
\text { Episkotister } \\
\text { Disc. }\end{array}$ & \begin{tabular}{|c|} 
Ratio of the in- \\
tensities of the \\
objects presented \\
to the respective \\
Eyes.
\end{tabular} & Lustre. & Stereoscopic Effect. \\
\hline Red. & $\begin{array}{c}1^{\circ} \\
4^{\circ} \\
28^{\circ} \\
210^{\circ}-270^{\circ}\end{array}$ & $\begin{array}{c}360.00 \\
90.00 \\
12.85 \\
1.71-1.33\end{array}$ & $\begin{array}{l}\text { None. } \\
\text { Do. } \\
\text { Faint. } \\
\text { Good. }\end{array}$ & $\begin{array}{l}\text { Partial. } \\
\text { Complete. } \\
\text { Do. } \\
\text { Do. }\end{array}$ \\
\hline Orange. & $\begin{array}{l}2^{\circ} \\
9^{\circ}\end{array}$ & $\begin{array}{r}180.00 \\
40.00\end{array}$ & $\begin{array}{l}\text { None. } \\
\text { Faint (never } \\
\text { becomes good) }\end{array}$ & $\begin{array}{l}\text { Complete. } \\
\text { Do. } \\
\text { Do. }\end{array}$ \\
\hline Yellow. & $\begin{array}{r}2^{\circ} \\
10^{\circ}\end{array}$ & $\begin{array}{r}\mathrm{r} 55.00 \\
31.00\end{array}$ & $\begin{array}{l}\text { None. } \\
\text { Slight. }\end{array}$ & $\begin{array}{c}\text { Complete. } \\
\text { Do. }\end{array}$ \\
\hline Green. & $\begin{array}{r}4^{\circ} \\
10^{\circ} \\
260^{\circ}\end{array}$ & $\begin{array}{r}80.00 \\
32.00 \\
1.23\end{array}$ & $\begin{array}{l}\text { None. } \\
\text { Faint. } \\
\text { Very good. }\end{array}$ & $\begin{array}{l}\text { Complete. } \\
\text { Do. } \\
\text { Do. }\end{array}$ \\
\hline Blue. & $\begin{array}{r}2^{\circ} \\
6^{\circ} \\
15^{\circ}\end{array}$ & $\begin{array}{r}62.50 \\
20.83 \\
8.33\end{array}$ & $\begin{array}{l}\text { None. } \\
\text { Slight. } \\
\text { Very fair. }\end{array}$ & $\begin{array}{l}\text { Complete. } \\
\text { Do. } \\
\text { Do. }\end{array}$ \\
\hline Violet. & $\begin{array}{r}2^{\circ} \\
4^{\circ} \\
110^{\circ} \\
250^{\circ} \\
\end{array}$ & $\begin{array}{r}90.00 \\
45.00 \\
25.71 \\
1.63 \\
.72 \\
\end{array}$ & $\begin{array}{l}\text { None. } \\
\text { Do. } \\
\text { Slight. } \\
\text { Brighter } \\
\text { Good. }\end{array}$ & $\begin{array}{l}\text { Partial. } \\
\text { Complete. } \\
\text { Do. } \\
\text { Do. } \\
\text { Do. }\end{array}$ \\
\hline Purple. & $\begin{array}{r}1^{\circ} \\
4^{\circ} \\
8^{\circ} \\
30^{\circ} \\
80^{\circ}\end{array}$ & $\begin{array}{r}180.00 \\
45.00 \\
22.50 \\
6.00 \\
2.22\end{array}$ & $\begin{array}{l}\text { None. } \\
\text { Do. } \\
\text { Slight. } \\
\text { Better. } \\
\text { Very good. }\end{array}$ & $\begin{array}{l}\text { Partial. } \\
\text { Complete. } \\
\text { Do. } \\
\text { Do. } \\
\text { Do. }\end{array}$ \\
\hline
\end{tabular}


Table Xlvil.-White. Observer, W.

(White constant in intensity, Colour changing).

\begin{tabular}{|c|c|c|c|c|}
\hline $\begin{array}{l}\text { Compared } \\
\text { Colour. }\end{array}$ & $\begin{array}{l}\text { Opening of the } \\
\text { Episkotister } \\
\text { Disc. }\end{array}$ & $\begin{array}{c}\text { Ratio of the in- } \\
\text { tensities of the } \\
\text { objects presented } \\
\text { to the respective } \\
\text { Eyes. }\end{array}$ & Lustre. & Stereoscopic Effect. \\
\hline Red. & $\begin{array}{r}2^{\circ} \\
4^{\circ} \\
8^{\circ} \\
95^{\circ}\end{array}$ & $\begin{array}{r}\text { I } 80.00 \\
90.00 \\
45.00 \\
3.78\end{array}$ & $\begin{array}{l}\text { None. } \\
\text { Do. } \\
\text { Slight. } \\
\text { Very good. }\end{array}$ & $\begin{array}{c}\text { Imperfect. } \\
\text { Complete. } \\
\text { Do. } \\
\text { Do. }\end{array}$ \\
\hline Orange. & $\begin{array}{r}2^{\circ} \\
8^{\circ} \\
24^{\circ}\end{array}$ & $\begin{array}{r}180.00 \\
45.00 \\
\text { I } 5.00\end{array}$ & $\begin{array}{l}\text { None. } \\
\text { Slight. } \\
\text { Fair. }\end{array}$ & $\begin{array}{c}\text { Coinplete. } \\
\text { Do. } \\
\text { Do. }\end{array}$ \\
\hline Yellow. & $\begin{array}{r}2^{\circ} \\
10^{\circ} \\
130^{\circ}\end{array}$ & $\begin{array}{r}209.03 \\
41.80 \\
3.21\end{array}$ & $\begin{array}{l}\text { None. } \\
\text { Slight. } \\
\text { Fair. }\end{array}$ & $\begin{array}{c}\text { Complete. } \\
\text { Do. } \\
\text { Do. }\end{array}$ \\
\hline Green. & $\begin{array}{r}2^{\circ} \\
4^{\circ} \\
16^{\circ} \\
65^{\circ}\end{array}$ & $\begin{array}{r}202.50 \\
101.25 \\
25.31 \\
6.23\end{array}$ & $\begin{array}{l}\text { None. } \\
\text { Do. } \\
\text { Slight. } \\
\text { Fair. }\end{array}$ & $\begin{array}{l}\text { Partial. } \\
\text { Complete. } \\
\text { Do. } \\
\text { Do. }\end{array}$ \\
\hline Blue. & $\begin{array}{r}1^{\circ} \\
3^{\circ} \\
6^{\circ} \\
100^{\circ}\end{array}$ & $\begin{array}{r}\text { I036.80 } \\
345.60 \\
\text { I } 72.80 \\
10.36\end{array}$ & $\begin{array}{l}\text { None. } \\
\text { Do. } \\
\text { Slight. } \\
\text { Fair. }\end{array}$ & $\begin{array}{c}\text { Imperfect. } \\
\text { Complete. } \\
\text { Do. } \\
\text { Do. }\end{array}$ \\
\hline Violet. & $2^{\circ}$ & $\begin{array}{r}360.00 \\
51.42\end{array}$ & $\begin{array}{l}\text { None. } \\
\text { Slight. }\end{array}$ & $\begin{array}{c}\text { Complete. } \\
\text { Do. }\end{array}$ \\
\hline Purple. & $\begin{array}{r}4^{\circ} \\
12^{\circ} \\
100^{\circ}\end{array}$ & $\begin{array}{r}720.00 \\
180.00 \\
60.00 \\
7.20\end{array}$ & $\begin{array}{l}\text { None. } \\
\text { Extremely } \\
\text { faint. } \\
\text { Slight. } \\
\text { Good. }\end{array}$ & $\begin{array}{c}\text { Imperfect. } \\
\text { Complete. } \\
\text { Do. } \\
\text { Do. }\end{array}$ \\
\hline
\end{tabular}


Results : Comparison of the results of these experiments with those of the similar experiments in white light shows some very interesting points of difference.

(I) With a considerable number of combinations no lustre appeared, no matter what the difference of intensity. (The limits were from equality to a ratio of $\mathrm{I}$ to 720 ). This seems difficult to account for, the more so as there is not very much regularity as to the colour combinations with which the lustre appears or fails. On the whole, it may perhaps be said that in most of the cases where no lustre appears the colours are either somewhat near each other in quality, so as to mix readily, or else are nearly complementary, so as to produce the strongest rivalry. The number of experiments, however, was not great enough, nor the regularity of the results sufficient, to make this induction conclusive.

2. Lustre does occur in many cases with smaller differences of brightness between the two retinal impressions than were required with uncoloured light to produce it. As before observed, when "good" lustre was once seen it continued till the disc was opened to its fullest extent. And in some cases, as when, for example, red was behind the disc and green on the other side, this meant that the intensities were practically equal. The lustre was frequently reported as "good" or "decided" when the intensities of the images were about as 3 or 4 to I. With uncoloured light, on the contrary, no lustre at all appeared unless one retinal image was from $1 \mathrm{I} / 2$ to 3 times as bright as the other; and "good" lustre required a ratio of at least 9 or io to $\mathrm{I}$.

3. Lustre does not occur with as great differences of intensity in coloured as in uncoloured light. That is to say, the upper limit is much lower with coloured light. The lustre was scarcely ever good when one impression was more than Io or I 2 times as bright as the other, and a ratio of about 50 to $\mathrm{I}$ is the extreme upper limit for the appearance of any lustre at all. With uncoloured light, on the other hand, the upper limit for good lustre varied from 375 to 920 to I and for any lustre at all the upper limit was about igoo to I. 
4. The opening of the disc required for the production of the stereoscopic effect is greater when the images differ in both colour and brightness than when they differ in brightness only. The complete combination often required an opening of $30^{\circ}$ or $40^{\circ}$, or even more, while not even a partial or inconstant combination in many cases appeared with an opening less than $15^{\circ}$ or $20^{\circ}$; whereas reference to the corresponding tables regarding uncoloured light shows that a partial stereoscopic effect appeared with an opening of $21^{\mathrm{o}} 2^{\circ}$ to $9^{\circ}$, and the complete effect did not require an opening greater than $14^{\circ}$ to $18^{\circ}$. From Tables XLVI and XLVII it will be seen that this phenomenon re-appears even in the combination of white and coloured light. A partial stereoscopic effect was frequently seen with an opening of only $\mathrm{I}^{\circ}$, and complete stereoscopic combination commonly did not require more than $4^{\circ}$. 



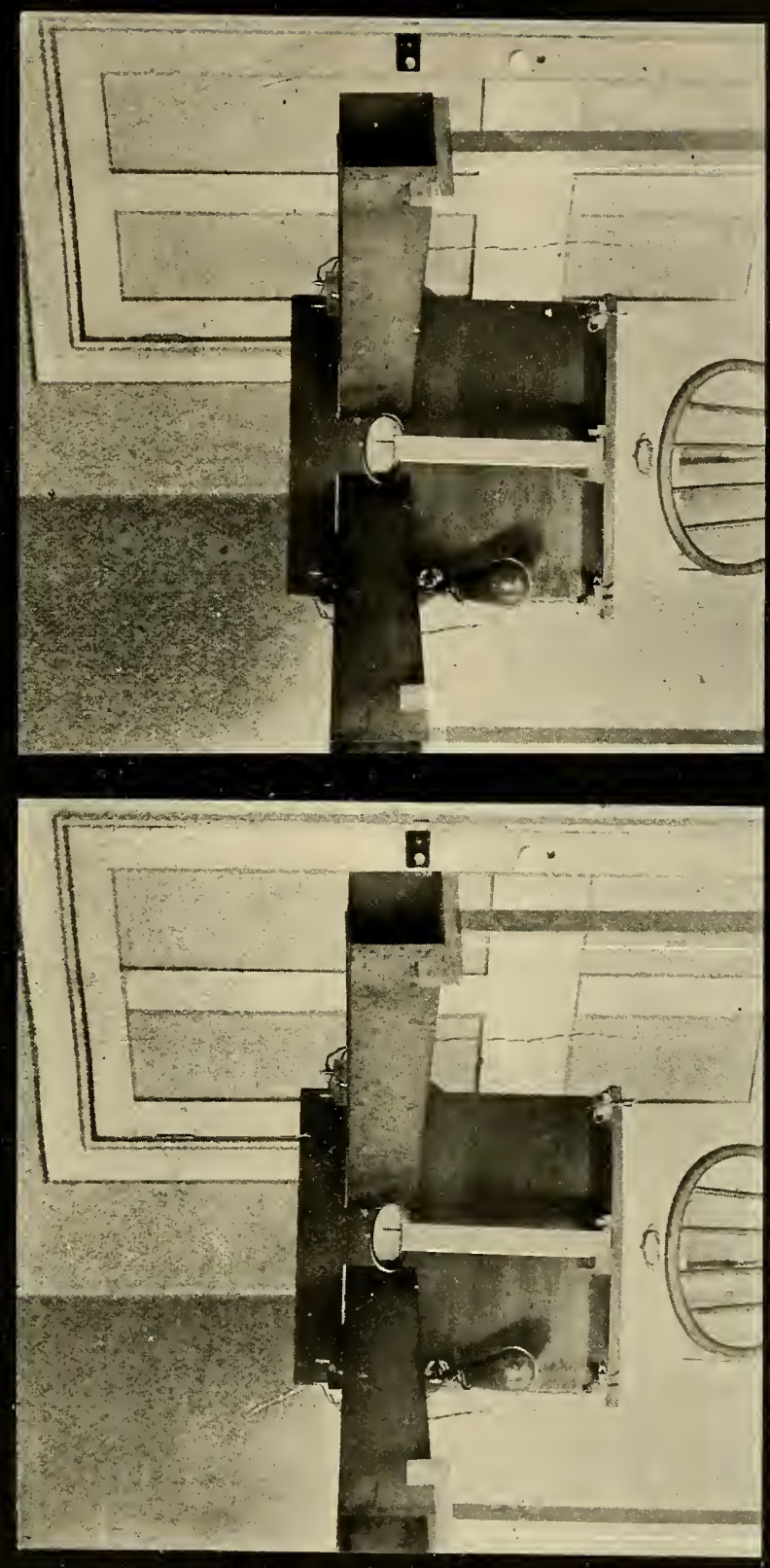

点 



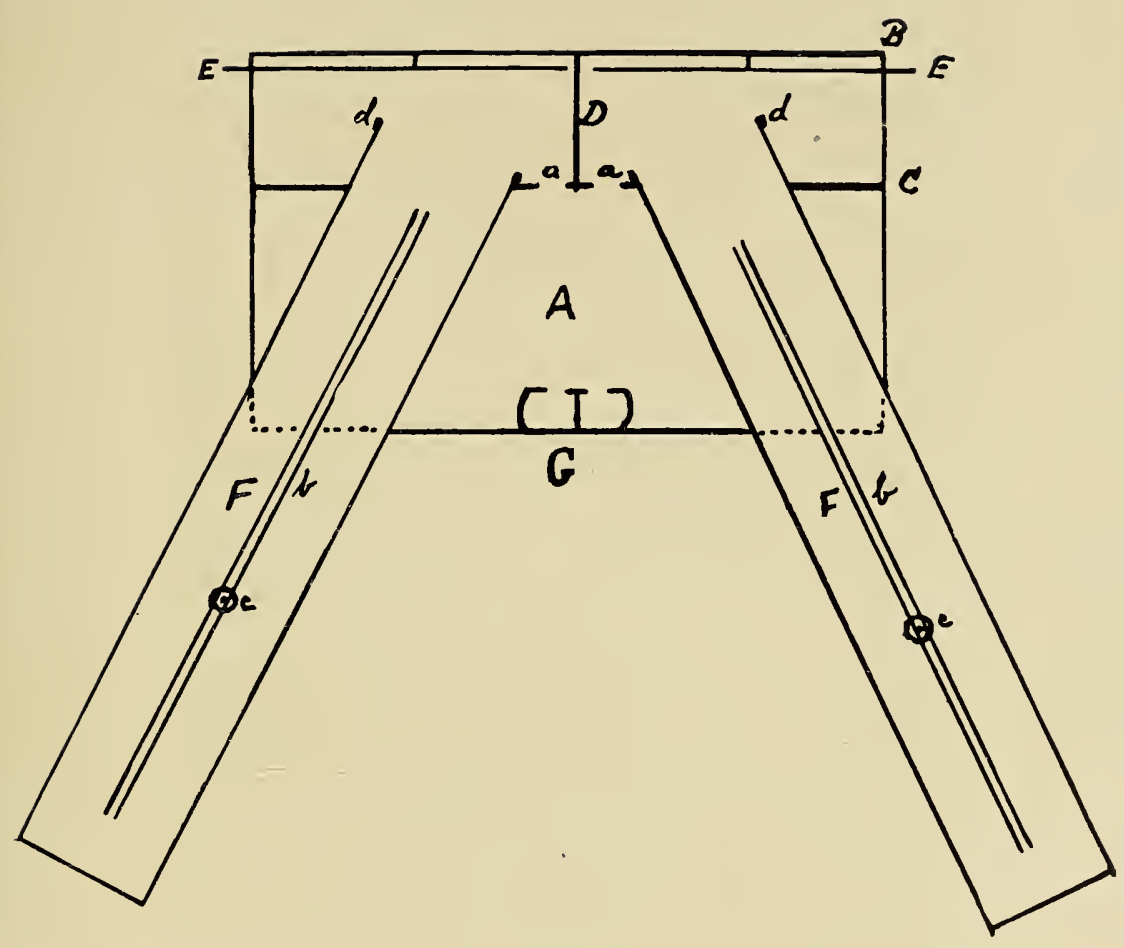

II․ II 



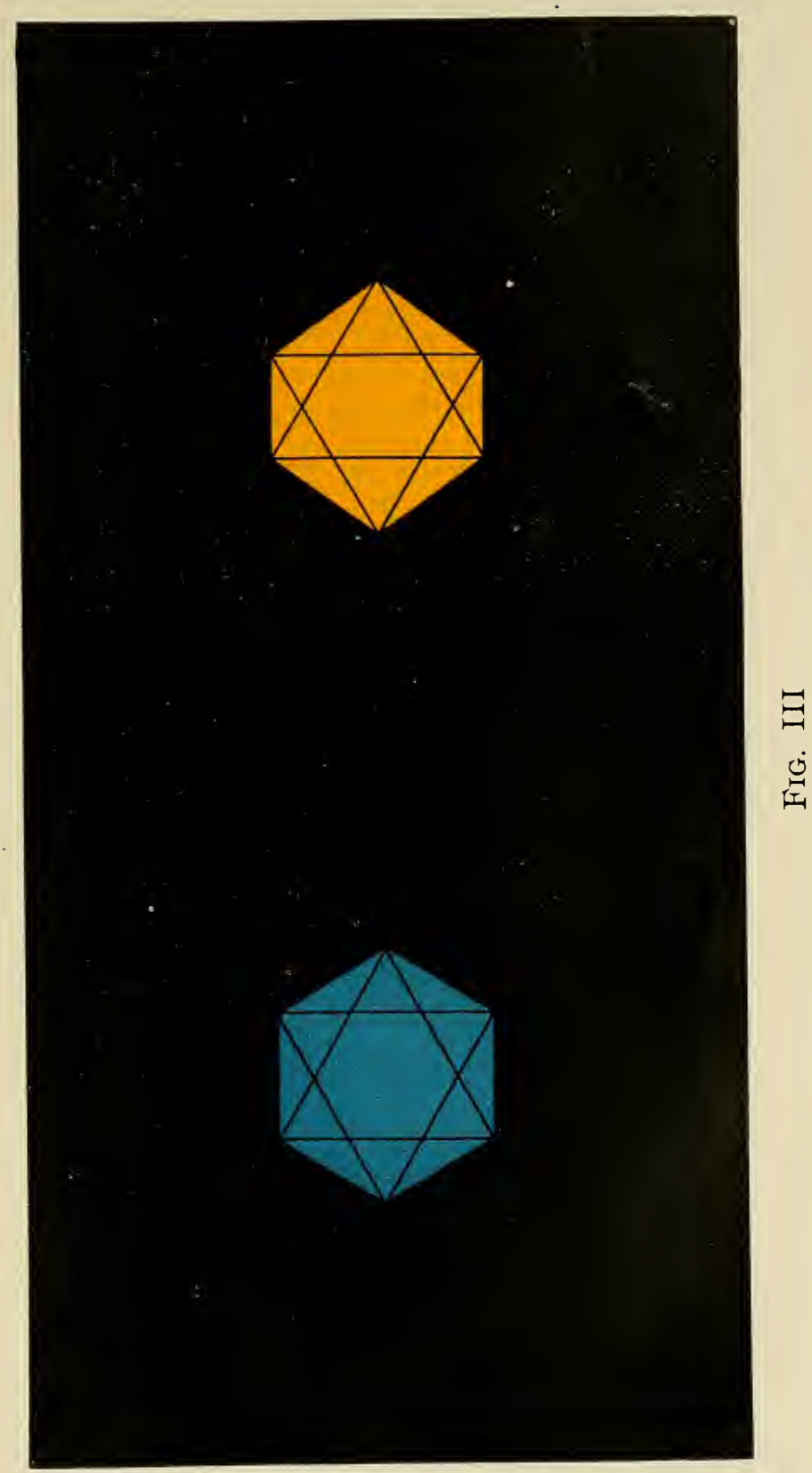




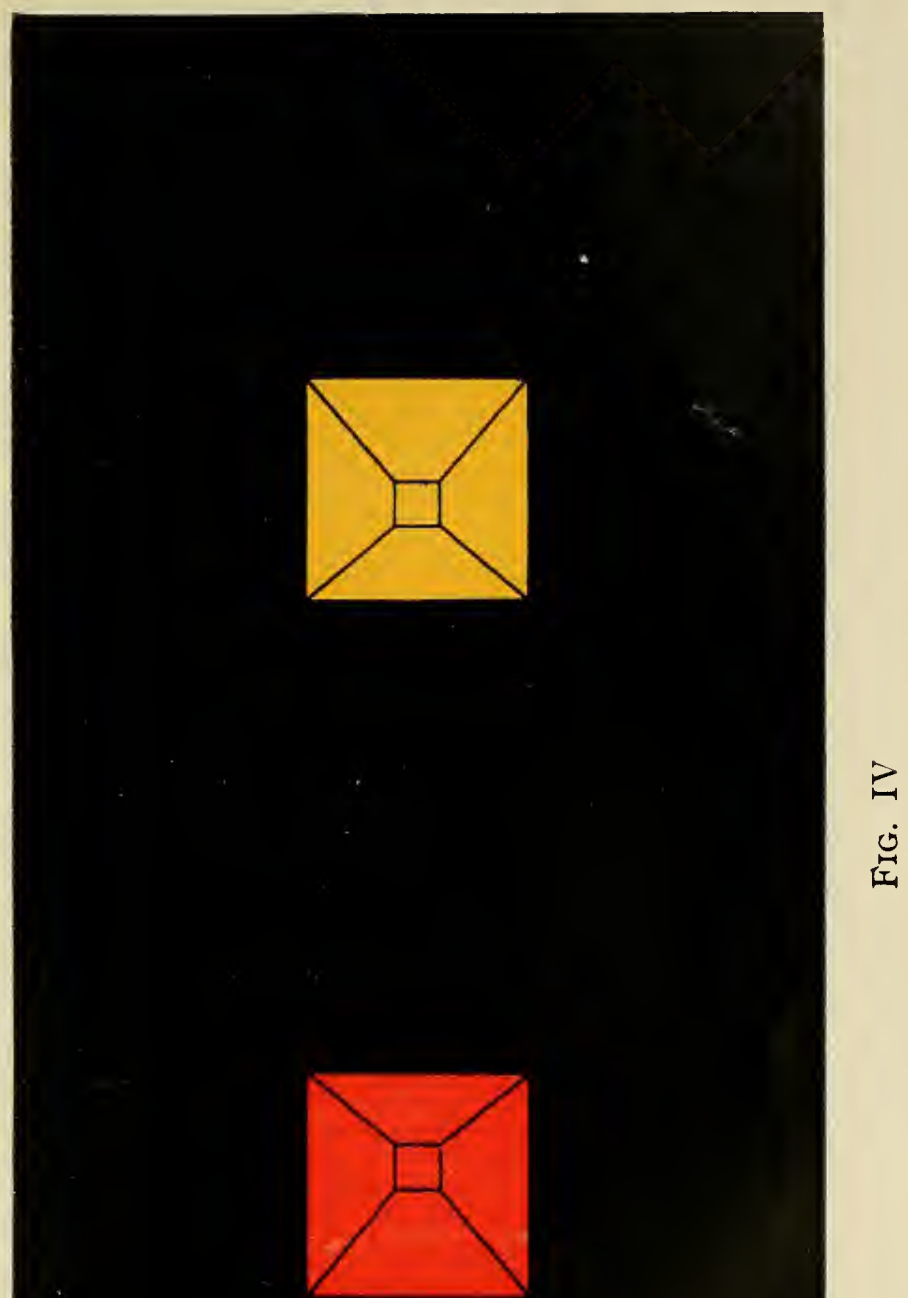



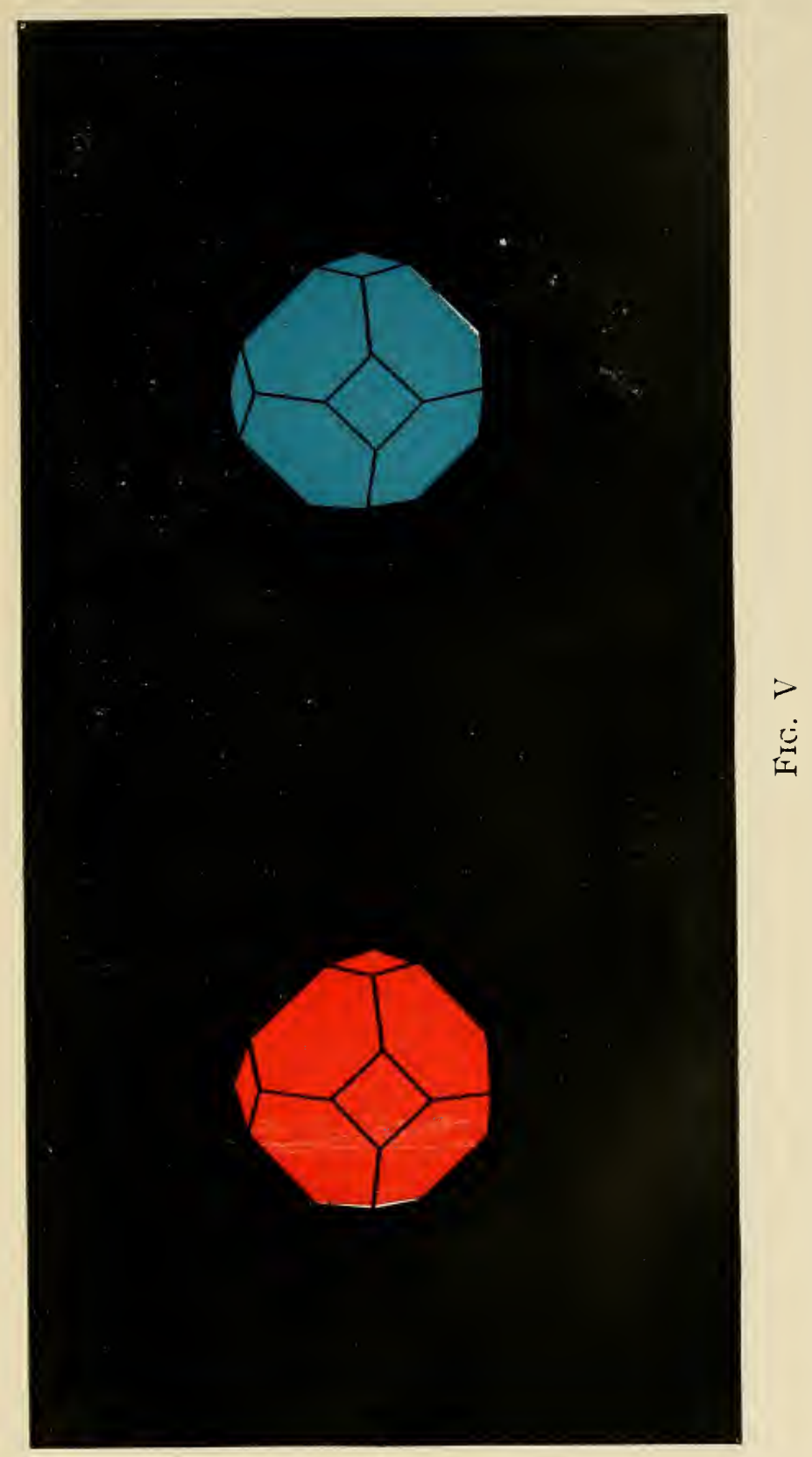





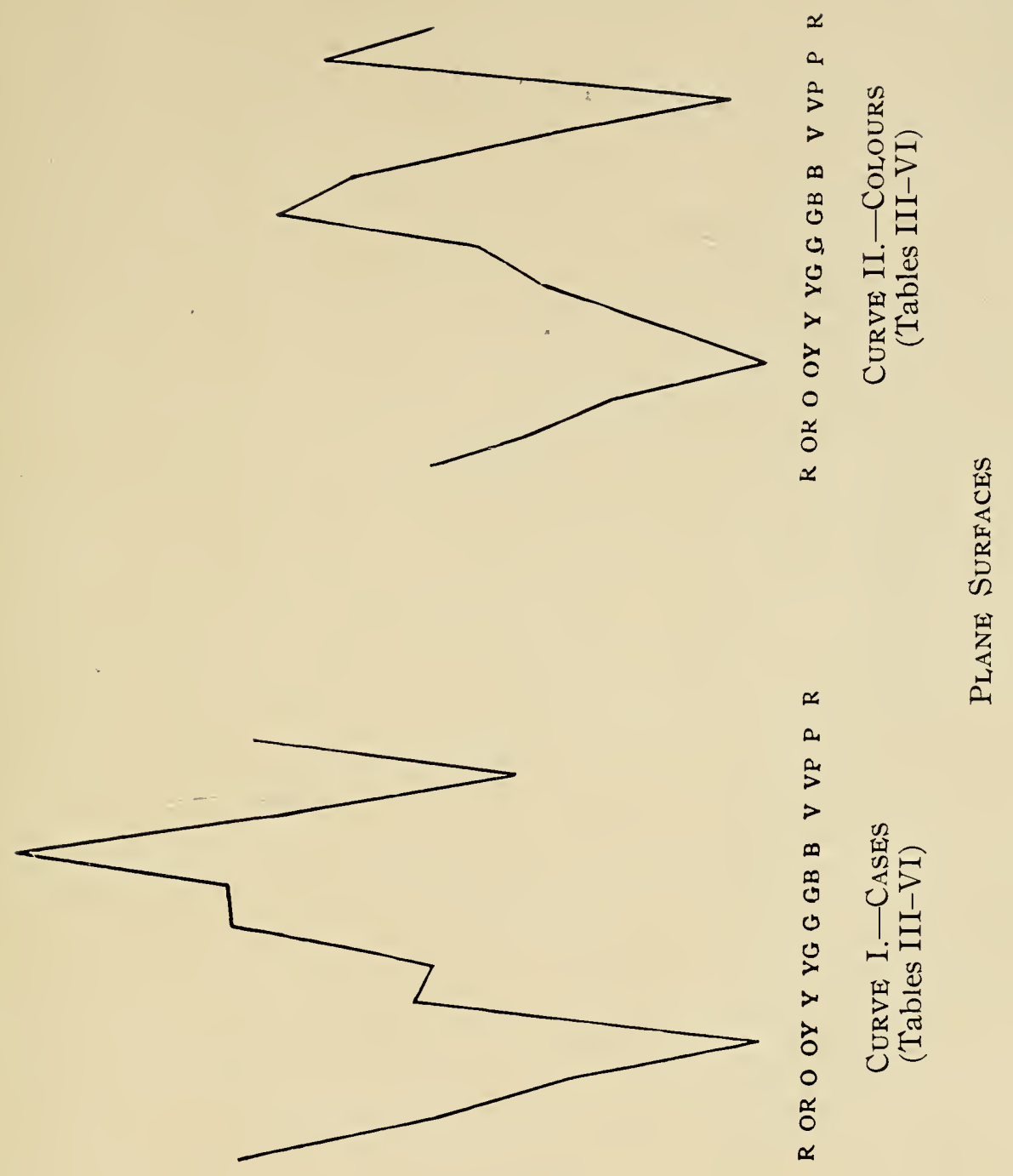





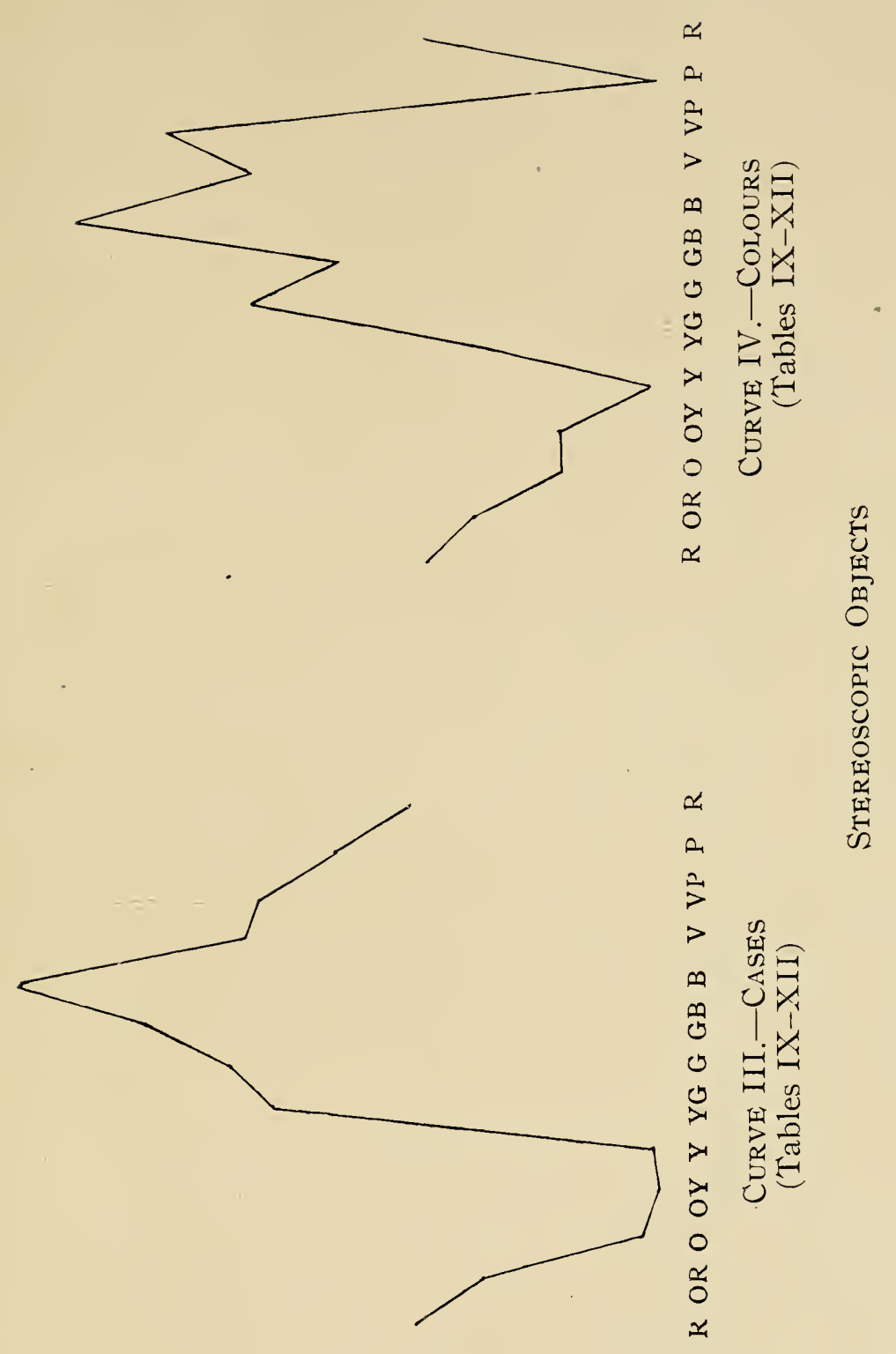




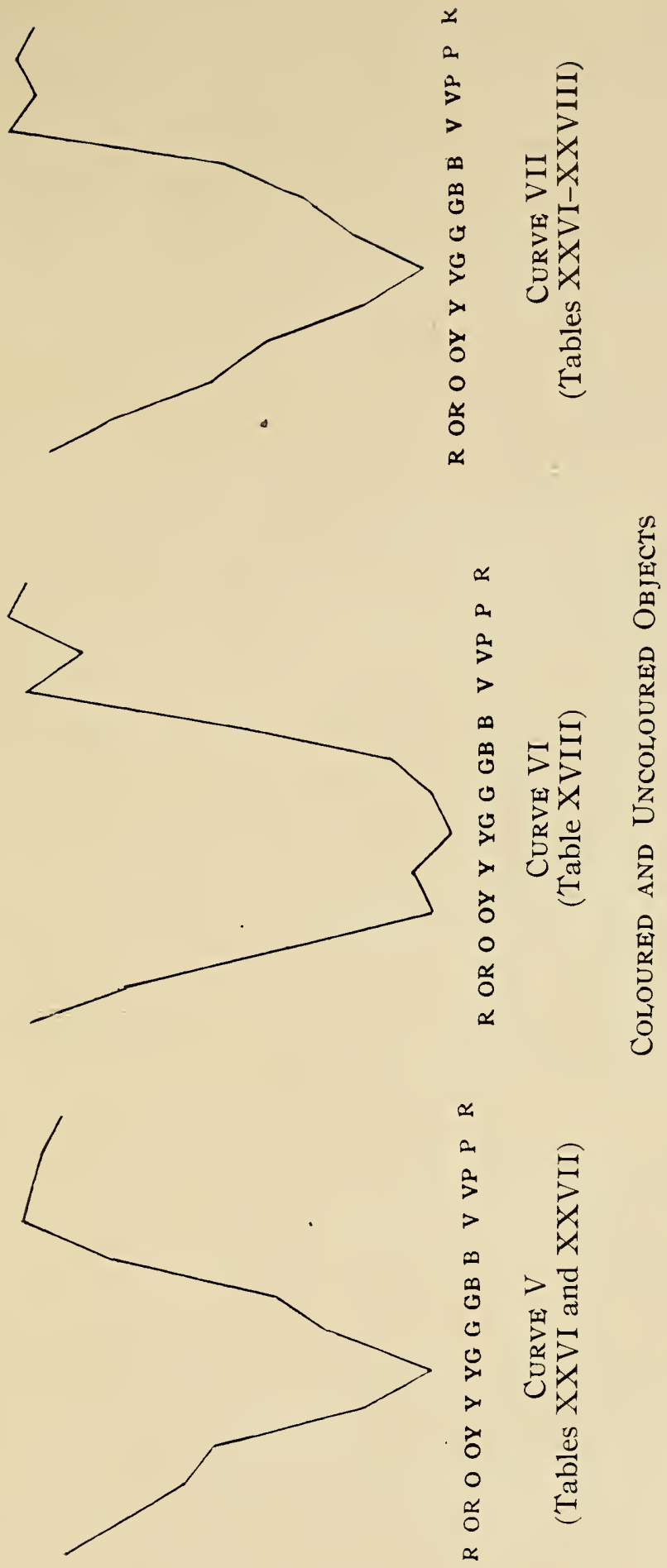










